\title{
Production of Mild Gasification Coproducts
}

\author{
Topical Report
}

December 1994

Work Performed Under Contract No.: DE-AC21-91MC27240

For

U.S. Department of Energy Office of Fossil Energy

Morgantown Energy Technology Center Morgantown, West Virginia

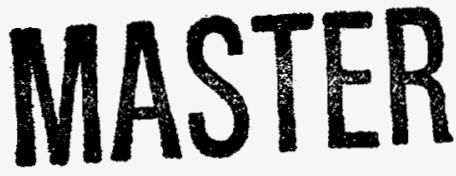

By

SGI Fuels, Incorporated

La Jolla, California

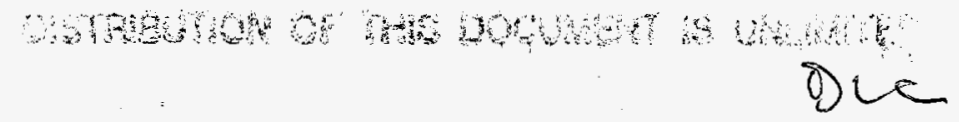




\section{DISCLAIMER}

This report was prepared as an account of work sponsored by an agency of the United States Government. Neither the United States Government nor any agency thereof, nor any of their employees, makes any warranty, express or implied, or assumes any legal liability or responsibility for the accuracy, completeness, or usefulness of any information, apparatus, product, or process disclosed, or represents that its use would not infringe privately owned rights. Reference herein to any specific commercial product, process, or service by trade name, trademark, manufacturer, or otherwise does not necessarily constitute or imply its endorsement, recommendation, or favoring by the United States Government or any agency thereof. The views and opinions of authors expressed herein do not necessarily state or reflect those of the United States Government or any agency thereof.

This report has been reproduced directly from the best available copy.

Available to DOE and DOE contractors from the Office of Scientific and Technical Information, 175 Oak Ridge Turnpike, Oak Ridge, TN 37831; prices available at (615) 576-8401.

Available to the public from the National Technical Information Service, U.S. Department of Commerce, 5285 Port Royal Road, Springfield, VA 22161; phone orders accepted at (703) 487-4650. 


\section{DISCLAIMER}

Portions of this document may be illegible in electronic image products. Images are produced from the best available original document. 


\title{
Production of Mild Gasification Coproducts
}

\author{
Topical Report
}

Work Performed Under Contract No.: DE-AC21-91 MC27240

For

U.S. Department of Energy

Office of Fossil Energy

Morgantown Energy Technology Center

P.O. Box 880

Morgantown, West Virginia 26507-0880

By

SGI Fuels, Incorporated

1200 Prospect Street, Suite 325

La Jolla, California 92037

December 1994 


\section{TABLE OF CONTENTS}

1.0 Introduction $\ldots \ldots \ldots \ldots \ldots \ldots \ldots \ldots \ldots \ldots \ldots \ldots \ldots \ldots$

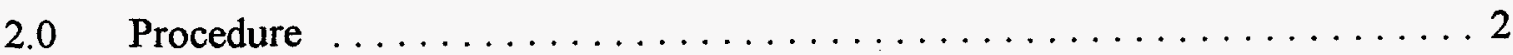

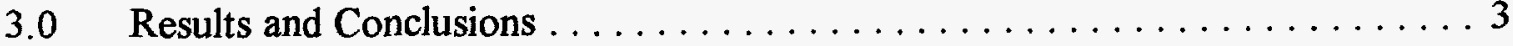

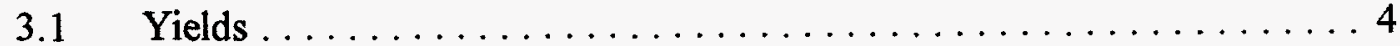

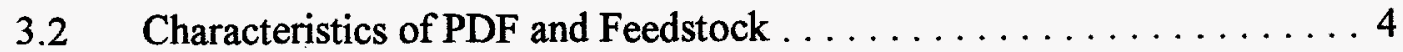

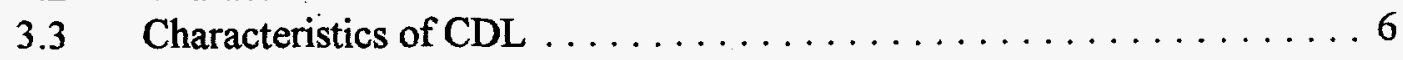

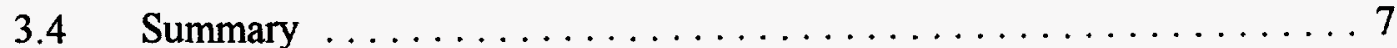

References $\quad \ldots \ldots \ldots \ldots \ldots \ldots \ldots \ldots \ldots \ldots \ldots \ldots$

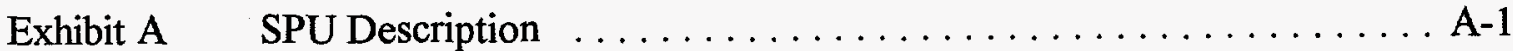




\section{APPENDICES}

Appendix A .................. Buckskin Topical Report

Appendix B $\ldots \ldots \ldots \ldots \ldots \ldots$. Sarpy Creek Topical Report

Appendix C ................... Usibelli Topical Report

Appendix D . . . . . . . . . . . . . Knife River Topical Report 


\section{TABLES}

Table $1 \quad$ Product Yield per Ton of Coal Processed $\ldots \ldots \ldots \ldots \ldots \ldots$

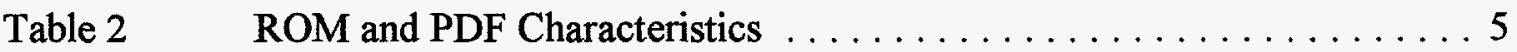

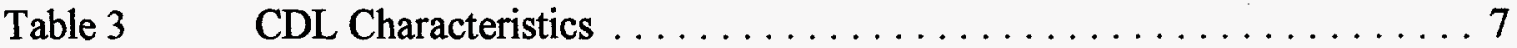




\subsection{INTRODUCTION}

The SGI International Liquids From Coal (LFC) Process is a mild pyrolysis, or mild gasification, treatment that upgrades low-rank coals by removing almost all of the moisture and a substantial portion of the volatile matter. The process produces two value-added co-products: a Coal Derived Liquid (CDL) and a solid Process Derived Fuel (PDF). A third co-product, a low-heating-value non-condensible gas, is recirculated and combusted in a commercial sized plant to provide drying and pyrolysis process heat.

The LFC Process consists of three basic steps. The first step, drying, involves essentially inert gas convectively raising the coal temperature and removing most of the moisture. The drying temperature is limited to ensure that no hydrocarbon gases evolve, and the flow rate is limited below fluidization levels for most of the coal particles. The second step, pyrolysis, consists of additional inert gas heating that raises the temperature of the dried coal so that more than half of the volatile matter is removed under a controlled temperature history that is characteristic for each particular coal and customer demand. The third step, finishing or conditioning, consists of exposure to a cooling inert gas that quenches the pyrolysis reaction, followed by controlled exposure to oxygen for the purposes of stabilization. The processed solid char is then brought to moisture equilibrium (much less than the parent coal's equilibrium level), and, if necessary, a dust suppressant is added to the PDF.

The PDF co-product is environmentally more attractive than the parent coal because a large fraction of the organic sulfur is removed with the volatile matter, and the heating value of the fuel is increased with a concurrent increase in combustion efficiency. When subjected to appropriate finishing steps, the PDF represents a stable, economically transportable, high-heat-value reactive combustion fuel with stable flame characteristics similar to natural gas.

The convective gas stream from the pyrolyzing step, laden with hydrocarbon vapors, is routed to a liquids collection system, using a combination of quench columns and electrostatic precipitators (ESP) to strip out the condensible fractions. The CDL co-product, collected from this gas stream, represents a significant contribution to the over-all economics of low-rank coal upgrading and is not found in other upgrading processes. The CDL is a low-sulfur oil with the approximated properties of No. 6 fuel oil but with characteristics that lend themselves to mild upgrading for higher-value end products.

The LFC Process falls into the category of pre-combustion clean coal technologies defined by the Department of Energy (DOE) as "mild gasification," and the PDF and CDL both qualify as "new fuel forms," in accordance with the Energy Policy Act of $1992 .^{3}$ As new fuel forms, official characterization is required to examine and classify these two mild gasification co-products and identify their marketplaces. To this end, SGI Fuels, Inc. entered into contract No. DE-AC91MC27240 with the Morgantown Energy Technology Center (METC) to produce liquid and solid co-product samples using the LFC Process. The commercial LFC Process is simulated with high fidelity by the Sample Production Unit (SPU) located in the SGI Development Center in Perrysburg, Ohio. Under the terms of the Contract, four (4) coals were sampled from three major coal resource regions of the United States. The coals are: Buckskin Mine Coal (Rosebud Seam 
in Wyoming and the Baseline Coal); Sarpy Creek Mine Coal (Rosebud Seam in Montana); Usibelli Mine Coal (Alaska); and, Knife River Mine Lignite (Williston Basin in North Dakota). Each of the coal samples was processed to produce the PDF and CDL. Subsequent to production of the co-product samples, testing and analysis was performed on each of the feedstock coals, the PDF sample and CDL sample. The entire process for each coal is reported in a separate Topical Report. For reference, the Topical Reports are appended to this report as:

Appendix A Buckskin Topical Report.

Appendix B Sarpy Creek Topical Report.

Appendix C Usibelli Topical Report.

Appendix D Knife River Topical Report.

This Final Report describes the procedures used to process the four coals and compares the resulting co-products.

\subsection{PROCEDURE}

Samples of coal were taken from freshly mined seam faces at the Buckskin Mine and Sarpy Creek Mine in the Powder River Basin, the Usibelli Mine in Alaska, and the Knife River Mine in the Williston Basin. Specific sampling procedures for each coal are described in the appendices. The samples were packaged in 55 gallon polyethylene drums with sealing lids for shipment to the SGI Development Center. After receipt of the samples, the coal was prepared for processing by crushing and sizing to $-5 / 8+1 / 4$ inch. Coal samples were prepared and packaged in sealed 5 gallon plastic pails for later shipment to laboratories for analysis and testing.

The sized coal was processed in the Sample Production Unit (SPU) which operates in a semi-continuous mode. Exhibit " $\mathrm{A}$ " is a description of the SPU.

The SPU consists of a heater module, which conditions the process gas to the desired flow rate and temperature, a reactor module, where the mild pyrolysis takes place, and a sample collection module, which collects the CDL produced by the mild pyrolysis. Operation of the SPU simulates the full scale operation of the LFC Process, embodied at the ENCOAL Demonstration Plant at the Triton Buckskin mine in Gillette, Wyoming. This simulation is accomplished by exactly matching the process gas temperature and gas velocity through the reactor module to that found at the Demonstration Plant. Temperature effects due to larger surface to volume ratio found in the SPU, when compared to the Demonstration Plant, are compensated for by the use of adiabatic heaters to maintain the reactor wall temperature at, or near, the temperature of the coal being processed. The heater module controls the composition of the convective heating gas, its flow rate, and its temperature. Drying and mild devolatilization take place in the well instrumented reactor module, while the solid co-product cooling and collection takes place in a char cooler/collector. The liquid co-product is collected in the collection module which consists of a gas cooler and electrostatic precipator (ESP). 
Data from the thermocouples and other instruments are recorded in an on-line computer archival and control system. The unit is capable of producing $4 \mathrm{~kg}$ of PDF and 1 liter of CDL per hour of operation with a considerable variation in processing conditions, so that co-products from semi-optimal processing can be obtained. For this study, the SPU operated in standard sequences, and no attempt was made to optimize the mild pyrolysis process with the heat rate, peak temperatures, or heating duration. The LFC Process, the SPU, and the ENCOAL Demonstration Plant are sufficiently flexible to produce co-products with a wide range of characteristics to meet the end users requirements.

For this project, the SPU was operated in two steps to produce the LFC Process co-products. First, a twelve (12") inch thick bed of coal was dried in the SPU using hot nitrogen or a synthetic flue gas composed mainly of nitrogen with small amounts of carbon dioxide and oxygen. The gas temperature and flow rates used in the drying step were the same for all coals processed. At a commercial plant, these process variables would be chosen to optimize the drying step for a specific coal. During the drying process, data, such as off-gas composition, on-gas flow rate and temperature, and bed temperatures and pressures produced from analysis with auxiliary lab equipment, are monitored and recorded by the control computer. (Buckskin coal processed at the ENCOAL Demonstration Plant is dried, analyzed and monitored in a similar manner.) The dried coal was then allowed to cool in sealed stainless steel containers. Once the dried coal was cool, it was stored under nitrogen in sealed 5 gallon plastic pails for later pyrolysis in the SPU.

In the second step, a twelve (12") inch thick bed of dried coal was pyrolyzed in the SPU using hot nitrogen or a synthetic flue gas composed mainly of nitrogen with small amounts of carbon dioxide, carbon monoxide, methane, and hydrogen. At a commercial plant, these process variables would be chosen to optimize the pyrolysis step for a specific coal to satisfy the customer's requirements of the co-products. During the pyrolyzing process, data produced from analysis with auxiliary lab equipment are monitored and recorded by the control computer. (Again, Buckskin coal processed at the ENCOAL Demonstration Plant is pyrolyzed, analyzed, and monitored in a similar manner.) During the pyrolysis step, the CDL was collected in ESP's, removed by gravity, and stored in sealed glass bottles.

After processing in the SPU, the pyrolyzed coal char, was allowed to cool in sealed stainless steel containers to about room temperature. Then, the char was spread in a thin layer on a plastic sheet to partially oxidize the char. Water was sprayed in a fine mist to partially rehydrate the char to produce simulated PDF. The water was pre-weighed so that $5 \%$ moisture would be added to the char. This final step in the laboratory process represents the finishing steps at the ENCOAL Demonstration Plant, and at this point, the final PDF product is ready for shipment to the customer.

The primary purpose of this effort is to produce significant quantities of the new fuel forms - PDF and CDL - for classification and evaluation. However, an evaluation of the suitability of the four coals to LFC processing is instructive. Therefore, upon completion of processing, samples of the co-products were evaluated at the SGI Development Center, Commercial Testing and Engineering (CTE), and the National Institute for Occupational Safety and Health (NIOSH). The results of these evaluations are presented in the appendices, and a discussion of the coals' upgrade potential and a summary of the evaluation results are presented below. 


\subsection{RESULTS AND CONCLUSIONS}

Several 55 gallon barrels containing coal samples from each of the four mines chosen for this study were received and crushed and sized at the SGI Development Center. About 350 to 550 pounds of raw coal from each mine were processed in the SPU using the LFC Process. As stated earlier, the individual coals were all processed with the same processing parameters. These parameters, on-gas temperatures, flow rates, and dwell time may well have produced more favorable results if they were varied to benefit the individual coal. Processing upgraded all of the coals by removing most of the water and more than half of the volatile matter. Along with the removal of the volatile matter, much of the organic sulfur was removed. The individual data items in the tables which follow are extracted from the appended Topical Report for the particular coal.

\subsection{YIELDS}

From each coal, PDF and CDL were produced, and Table 1 contains the expected yields from processing one ton $(2000 \mathrm{lbs}$.) of the coals evaluated. Also shown in the table is a description of the relative ease of processing.

TABLE 1

PRODUCT YIELD PER TON OF COAL PROCESSED

\begin{tabular}{|l|c|c|c|c||}
\hline & BUCKSKIN & SARPY CREEK & USIBELLI & KNIFE RIVER \\
\hline PDF (lbs.) & 942 & 1,026 & 960 & 763 \\
\hline CDL (bbls.) & 0.70 & 0.44 & 0.47 & 0.28 \\
\hline $\mathrm{H}_{2} \mathbf{O}$ & 600 & 460 & 500 & 660 \\
\hline $\begin{array}{l}\text { Relative Ease } \\
\text { of Processing }\end{array}$ & Easy & Easy & Easy & Difficult \\
\hline
\end{tabular}

As can be seen from Table 1, LFC processing of Buckskin coal produces significantly more CDL than the other three coals evaluated at these processing parameters. Both the Usibelli and Sarpy Creek coals yield sufficient PDF and CDL quantities to be attractive LFC Process upgrading candidates.

However, the Knife River coal was difficult to process and did not yield as much PDF and CDL as the other coals, mainly because the coal is $33 \%$ moisture with agglomerating tendencies (Appendix D, Table II: SGI ASTM Proximate Analysis of Raw Coal).

An evaluation of a candidate coal for upgrading is incomplete without an examination of the PDF and CDL characteristics, namely the increased energy density efficiency and sulfur dioxide emission potential for the PDF and pour point and mutagenic nature of the CDL. 


\subsection{Characteristics of PDF AND FEEDSTOCK}

As displayed in Table 2 , the heating value for each coal increases significantly when upgrading and, in most cases, sulfur dioxide emissions are reduced.

TABLE 2

ROM AND PDF CHARACTERISTICS

\begin{tabular}{|c|c|c|c|c|}
\hline & $\begin{array}{l}\text { BUCKSKIN } \\
\text { APPENDIX A }\end{array}$ & $\begin{array}{c}\text { SARPY CREEK } \\
\text { APPENDXX B }\end{array}$ & $\begin{array}{r}\text { USIBELLI } \\
\text { APPENDIX C }\end{array}$ & $\begin{array}{c}\text { KNIFE RIVER } \\
\text { APPENDIX D }\end{array}$ \\
\hline $\begin{array}{l}\text { ROM heating } \\
\text { value, BTu/b }\end{array}$ & 8,360 & 9,210 & 8,280 & 7,370 \\
\hline $\begin{array}{l}\text { PDF heating } \\
\text { value, Brv/h }\end{array}$ & 12,550 & 12,140 & 11,580 & 11,940 \\
\hline $\begin{array}{l}\text { ROM SO } \\
\text { emissions, } \\
\text { lb. SO, } \\
\text { lomBTu }\end{array}$ & 1.26 & 1.0 & 0.4 & 3.7 \\
\hline $\begin{array}{l}\text { PDF } \mathrm{SO}_{2} \\
\text { emissions, } \\
\text { lb. SO } \mathrm{SO}_{2} \text { MMBTu }\end{array}$ & 1.16 & 1.67 & 0.5 & 2.3 \\
\hline $\begin{array}{l}\text { ROM organic } \\
\text { sulfur content, } \\
\text { lb. Organic } \text { / Ton } \\
\text { ROM }\end{array}$ & 4.2 & 5.4 & 2.6 & 14.2 \\
\hline $\begin{array}{l}\text { PDF organic } \\
\text { sulfur content, } \\
\text { lb. Organic } S \text { / Ton } \\
\text { PDF }\end{array}$ & 3.8 & 3.5 & 1.5 & 3.5 \\
\hline
\end{tabular}

However, in all cases, the LFC Process removed a considerable quantity of organic sulfur from the parent coal. Some discussion concerning the effects of sampling on sulfur variability is warranted.

For the Buckskin run-of-mine (ROM) coal, the initial ultimate analysis sulfur content was determined to be $0.35 \%$ on a dry basis (Appendix A, Table IV: CTE Coal Analysis). Subsequent and more repetitive testing found the sulfur content to average $0.73 \%$, as explained in the following extraction from Section 4 (including Table XI: "Buckskin Coal and PDF Sulfur Variability") in Appendix A.

"The Buckskin coal is a low sulfur coal, containing, from the December 1992 CTE Ultimate analysis, $0.35 \%$ sulfur on a dry basis. Subsequent analyses performed by CTE in June 1993, and reflected in Table XI, resulted in a dry basis average sulfur content for Buckskin of $0.73 \%$. At the depicted levels of sulfur, the metric for the $\mathrm{SO}_{2}$ production in the coal is as little as $0.59 \mathrm{lbs}$. $\mathrm{SO}_{2} / \mathrm{MMBTU}$. Using the average sulfur content of the June tests of Buckskin coal of $0.73 \%$ shown in Table XI, the usage metric becomes $1.26 \mathrm{lbs}$. $\mathrm{SO}_{2} \mathrm{MMBTU}$. 
Based on the December 1992 CTE Ultimate analysis results, the metric for the sulfur in Buckskin simulated PDF would produce $0.86 \mathrm{lbs}$. $\mathrm{SO}_{2} / \mathrm{MMBTU}$. Using the average sulfur content in the PDF of $0.75 \%$ as determined from the tests conducted in June 1993 by CTE and shown in Table XI, the average metric for $\mathrm{SO}_{2}$ production is $1.16 \mathrm{lbs}$. $\mathrm{SO}_{2} \mathrm{MMBTU}$. Because of the variability of sulfur in the CTE test results, as shown in Table XI, it is not possible to make a direct correlation of the ROM coal and the simulated PDF. However, it can be generally concluded using the average values from Table XI, that the LFC Process beneficially reduces the amount of $\mathrm{SO}_{2} \mathrm{MMBTU}$ in the simulated PDF."

"Table XI Buckskin Coal and PDF Variability"

\begin{tabular}{|c|c|c|}
\hline Sample Date & $\begin{array}{c}\text { Buckskin Coal Sulfur } \\
\text { (dry basis) }\end{array}$ & $\begin{array}{l}\text { Buckskin PDF Sulfur } \\
\text { (dry basis) }\end{array}$ \\
\hline $12 / 2 / 92$ & $0.35 \%$ & $0.56 \%$ \\
\hline $6 / 3 / 93$ & & $0.49 \%$ \\
\hline $6 / 4 / 93$ & $0.97 \%$ & $0.96 \%$ \\
\hline $6 / 5 / 93$ & & $0.53 \%$ \\
\hline $6 / 6 / 93$ & & $0.57 \%$ \\
\hline $6 / 7 / 93$ & $0.73 \%$ & $0.74 \%$ \\
\hline $6 / 10 / 93$ & & $0.89 \%$ \\
\hline $6 / 11 / 93$ & & $0.72 \%$ \\
\hline $6 / 12 / 93$ & $0.57 \%$ & \\
\hline $6 / 12 / 93$ & $0.45 \%$ & \\
\hline $6 / 12 / 93$ & $1.15 \%$ & $0.58 \%$ \\
\hline $6 / 13 / 93$ & $0.77 \%$ & \\
\hline $6 / 13 / 93$ & $0.61 \%$ & \\
\hline $6 / 13 / 93$ & $0.56 \%$ & $1.29 \%$ \\
\hline Average of June '93 Results & $0.73 \%$ & $0.75 \%$ \\
\hline Average lbs. $\mathrm{SO}_{2} / \mathrm{MMBTU}$ & 1.26 & 1.16 \\
\hline
\end{tabular}

Therefore, one concludes that proximate and ultimate analysis must be performed on a wide range of seam samples to produce reliable results.

This conclusion is supported further with the Sarpy Creek results in the following extraction from Section 3.3 in Appendix B, Sarpy Creek Topical Report, including Table VIII: "Raw Coal and PDF Sulfur Form Comparisons." 
"Based on CTE's analysis, the sulfur dioxide emission for the simulated PDF is $1.67 \mathrm{lbs}$. $\mathrm{SO}_{2}$ MMBTU. However, closer examination of the PDF sulfur forms indicate that the ROM sample used to produce the PDF sample had more pyritic sulfur than the ROM sample tested by CTE. As shown in Table VIII, the CTE analysis of ROM sulfur forms indicates that the $347 \mathrm{lbs}$. of raw coal would contain $0.76 \mathrm{lbs}$. of pyritic sulfur and $1.21 \mathrm{lbs}$. of organic sulfur. The CTE analysis of PDF sulfur forms indicates that the $250 \mathrm{lbs}$. of processed coal (PDF) would contain $1.70 \mathrm{lbs}$. of pyritic sulfur and $0.88 \mathrm{lbs}$. of organic sulfur. This indicates a less than expected $27 \%$ reduction of the organic sulfur and impossible production of $0.94 \mathrm{lbs}$. of pyritic sulfur. Also shown in Table VIII, the CTE proximate analysis indicates that the $347 \mathrm{lbs}$. of raw coal would contain $173 \mathrm{lbs}$. of fixed carbon and $33.6 \mathrm{lbs}$. ash. The CTE proximate analysis indicates that the $250 \mathrm{lbs}$. of processed coal (PDF) would contain $163 \mathrm{lbs}$. of fixed carbon and $34.9 \mathrm{lbs}$. of ash, an improbable $10 \mathrm{lbs}$. decrease in fixed carbon and $1.3 \mathrm{lbs}$. increase in ash. Since the LFC Process removes volatile matter and leaves the fixed carbon and ash, these results indicate that the raw coal sample used to produce PDF contained more ash and less fixed carbon than the raw coal sample analyzed by CTE. The ash contains the pyritic sulfur forms, and therefore, the predicted $\mathrm{SO}_{2}$ emissions increase is artificial and caused by the sulfur variability in the seam and samples."

"Table VIII Raw Coal and PDF Sulfur Form Comparisons"

\begin{tabular}{|l|c|c||}
\hline \multicolumn{1}{|c|}{ Constituent } & $\begin{array}{c}\text { Projected Weight } \\
\text { in Raw Coal (lbs.) }\end{array}$ & $\begin{array}{c}\text { Projected Weight } \\
\text { in PDF (lbs.) }\end{array}$ \\
\hline Pyritic Sulfur & 0.76 & 1.70 \\
\hline Organic Sulfur & 1.21 & 0.88 \\
\hline Fixed Carbon & 173.1 & 162.7 \\
\hline Ash & $\mathbf{3 3 . 6}$ & $\mathbf{3 4 . 9}$ \\
\hline
\end{tabular}

From the Sarpy Creek discussion, it is clear that the predicted increase in $\mathrm{SO}_{2}$ emissions is artificial even though both the ROM test sample and the PDF test sample originated from the same sample of $347 \mathrm{lbs}$. of coal from the Sarpy Creek Mine.

The accuracy of individual test results, and projections therefrom, would be greatly improved for both the Buckskin Coal and the Sarpy Creek Coal with a larger number of feedstock coal and PDF samples.

It is clear that in all of the test cases the heating value of each of the coals will be significantly increased in the PDF product through the LFC Process; and, the $\mathrm{SO}_{2}$ emissions will be reduced when using the solid product as a fuel.

\subsection{ChaRACTERISTICS OF CDL}

The characteristics of the CDL produced from the four coals evaluated are shown in Table 3 . The mutagenic testing was done by the National Institute for Occupational Safety and Health, and the NIOSH report is included in each appendix. The CDL produced from the Knife River coal has the lowest pour point, but none of the CDL's had pour points above $110^{\circ} \mathrm{F}$. All of the CDL's appear refinable, and the Sarpy Creek CDL is the only one that exhibits more than weak mutagenic tendencies and some potential for causing DNA damage. 
TABLE 3

CDL CHARACTERISTICS

\begin{tabular}{|l|c|c|c|c||}
\hline & BUCKSKIN & SARPY CREEK & USIBELLI & KNIFE RIVER \\
\hline Pour Point ( $\left.{ }^{\circ} \mathbf{F}\right)$ & $95-110$ & $95-110$ & $95-110$ & $65-100$ \\
\hline $\begin{array}{l}\text { Specific } \\
\text { Gravity }\end{array}$ & 1.02 & 1.04 & 1.02 & 1.08 \\
\hline API Gravity & $6.6^{\circ}$ & $4.2^{\circ}$ & $6.6^{\circ}$ & $-0.7^{\circ}$ \\
\hline $\begin{array}{l}\text { H/C Molar } \\
\text { Ratio }\end{array}$ & 1.28 & 1.29 & 1.36 & 1.20 \\
\hline $\begin{array}{l}\text { Mutagenic } \\
\text { Tendencies }\end{array}$ & Weak & Mutagenic & Weak & Weak \\
\hline Refinability & Refinable & Refinable & Refinable & Refinable \\
\hline
\end{tabular}

\subsection{SUMMARY}

In summary, the co-product production runs performed by the SGI Development Center yielded sufficient simulated $\mathrm{PDF}^{*}$ and $\mathrm{CDL}$ to meet the production needs for each of the four coals. The LFC Process appears to be an attractive method for upgrading all of the coals except for the Knife River Coal because of its limited yield and difficulty in processing. The Buckskin coal appears to be a slightly stronger candidate for upgrading than the other three coals because it has the greatest CDL yield and a more than $50 \%$ increase in heating value from ROM to PDF. (LFC processing of Usibelli and Sarpy Creek coal produces more PDF, but the heating value increase is less and the oil yields are low. Processing Knife River coal produces much less PDF but a greater heating value increase because of its higher moisture content). Finally, in all cases, the LFC Process removed significant percentage of the organic sulfur, clearly demonstrating its coal cleaning potential.

* For Buckskin ROM Coal, the PDF yield reported from this project is supported by preliminary results of the ENCOAL Demonstration Plant in Wyoming.

\section{REFERENCES}

1. U.S. Department of Energy, December 1992, Clean Coal Technology

Demonstration Program Update, pp. 1-10.

2. Nickell, R.E., "Refining the Art of Coal Upgrading", WORLD COAL, October 1993, pp. 28-35.

3. U.S. Energy Policy Act 1992, October 1992, House of Representatives Report 102-1018. 


\section{Exhibit A}

\section{SPU Description}

The Sample Production Unit (SPU) has been commissioned to prepare solid and liquid samples from samples of coal or lignite. The unit has been designed for portability but is set up indoors in the Development Laboratory. An equipment schematic diagram of the SPU is given in Figure A-1.

Figure A-1 SGI LFC SAMPLe Procuction UNIT - SPU

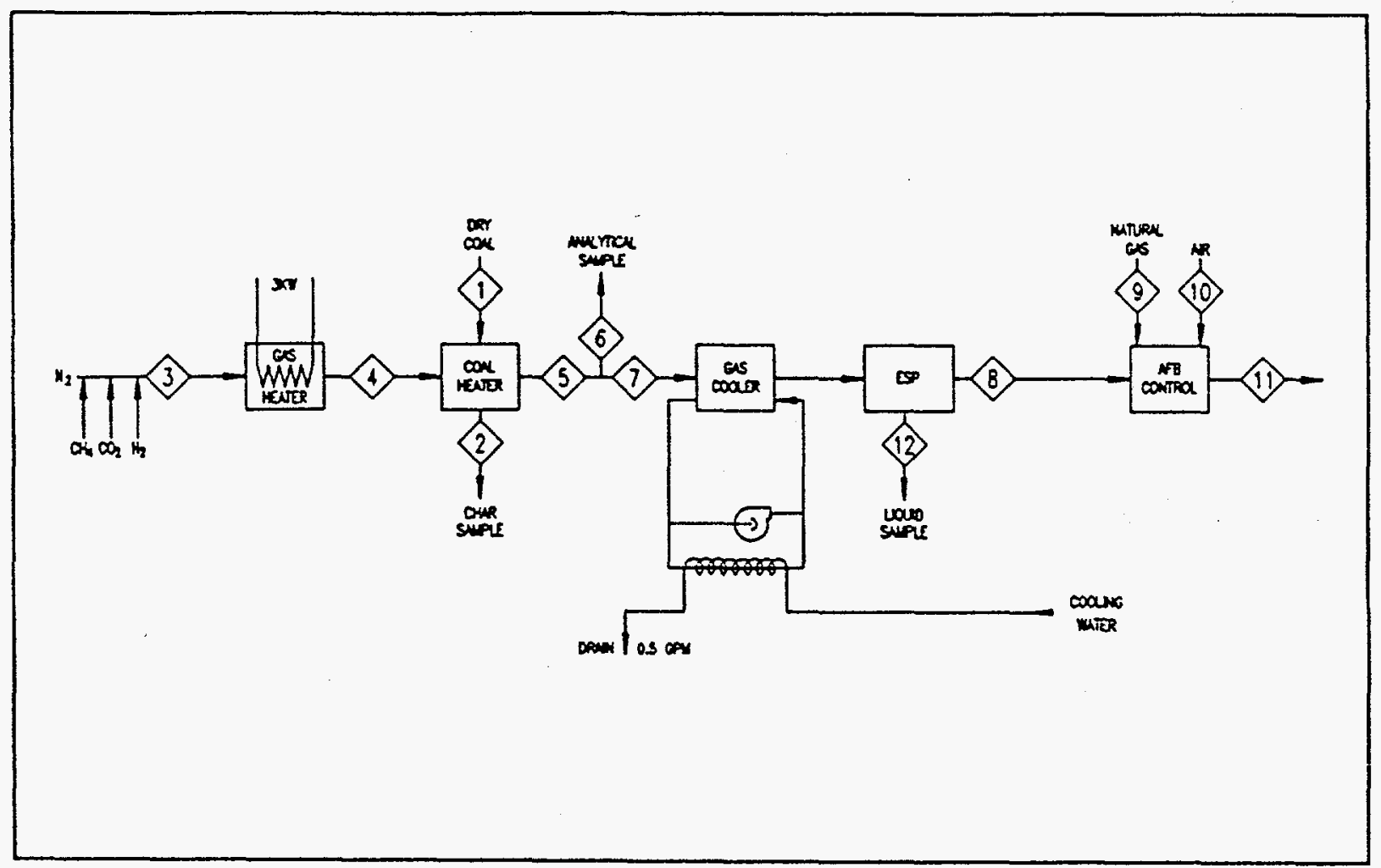

The SPU functions as follows: Heated nitrogen gas is passed through a bed of dried coal in a closed system. The hot gas heats the coal in the absence of oxygen and forces vapors from the coal. After heating, the coal is discharged as a carbon rich solid sample to be cooled in sealed containers. Vapors that are driven from the coal are piped to downstream cooling and condensing equipment. As a result of cooling the off-gas, some of the coal vapor will condense into droplets of coal liquid mist. The cooled off-gas aerosol is then passed through a voltage regulated Electrostatic Precipitator (ESP). The temperature of the ESP is maintained above the pour point of the Coal Derived Liquid (CDL). The precipitated liquid flows by gravity into a sump. The 
ESP including the sump is a closed system and will allow no liquid or vapor escape. The coal liquid sample, after removal from the sump, is stored in sealed containers prior to further handling. The cleaned carrier gas is passed through an afterburner control device maintained at $1600^{\circ} \mathrm{F}$ before being discharged from the SPU to the atmosphere.

The SPU has been designed as a versatile modular component unit. By coupling the gas heater and coal heater modules, the SPU can be used to dry the feed coal samples prior to processing the dried coal as described above. In this mode, dry nitrogen gas is heated and then used to heat the coal. It carries the moisture from the coal through the analytical section to the afterburner control device, thus by-passing the downstream oil-collecting modules during the drying process.

Procedurally, a sample of wet coal is crushed, riffled and sized. The feed coal is then dried as described above and stored in sealed metal containers. After all the coal has been dried, the SPU is preheated to operating conditions. All systems of the SPU are fully operational before the dried coal sample is processed. A computer is used to monitor and control the process variables of temperature, pressure, and flow.

Vapors released from the hot coal are carried from the reactor in the nitrogen carrier gas to the downstream ESP processing equipment where it is recovered as CDL. The processed solid sample is cooled over a period of time in a sealed metal container that is set aside from the operating SPU. After cooling, the solid samples are inerted to produce SPU processed Process Derived Fuel (PDF) but not treated by the dust suppressor, MK.

The SPU processed PDF and CDL is then carefully packaged and directed to other analytical laboratories or interested clientele.

Operation of the SPU is planned for up to 10 hours in duration; however, sample processing in a batch mode is within the capability of the unit. 


\section{APPENDIX A}

SAMPLE PRODUCTION REPORT FOR BUCKSKIN (BASELINE) COAL

FOR "PRODUCTION OF MILD GASIFICATION CO-PRODUCTS" PROJECT

Topical Report (FINAL)

By:

D. A. Horne

J. C. Castro

December 4, 1994

Work Performed Under Contract NO.: DE-AC21-91MC27240

For:

U.S. Department of Energy

Morgantown Energy Technology Center

Morgantown, West Virginia

By:

SGI Fuels, Incorporated

La Jolla, California 


\section{EXECUTIVE SUMMARY}

Six (6) 55 gallon barrels of Buckskin subbituminous coal were sampled from the Buckskin Mine located near Gillette, Wyoming, on 4 August 1992. These samples were crushed and sized to $-5 / 8 "+$ 1/4" for processing to produce Liquids From Coal (LFC) liquid and solid co-products. A total of 313 lbs. of raw coal was processed through SGI's Sample Production Unit (SPU) producing 147.5 lbs of simulated Process Derived Fuel (PDF) and $35 \mathrm{lbs}$. of Coal Derived Liquid (CDL) co-products. Testing results show that the processing upgraded the coal by removing the water from the coal (30\% by weight), increasing its heating value from 8,362 to $12,550 \mathrm{BTU} / \mathrm{lb}$. The differences between the PDF and ROM coal sulfur are within tolerances attributable to the coal variability, and therefore, no conclusion is made regarding the effect of the $\mathrm{LFC}$ Process on $\mathrm{SO}_{2}$ emissions. The $\mathrm{SO}_{2}$ emission rates for both the PDF and ROM coal are at or below clean air act limits.

The CDL has properties similar to tar sand oil with a pour point in the $95^{\circ}$ to $110^{\circ} \mathrm{F}$ range. The specific gravity of the oil is near 1.02 giving an API gravity of $6.6^{\circ}$. Most of the hydrogen compounds in the CDL are involved in paraffinic structures $\left(-\mathrm{CH}_{2}-\right)$. The $\mathrm{CDL}$ has a molar $\mathrm{H} / \mathrm{C}$ ratio of 1.28. This compares to 2.2 for simple paraffins, and 0.8 for naphthalene.

The CDL is only weakly mutagenic as determined by NIOSH. 


\section{TABLE OF CONTENTS}

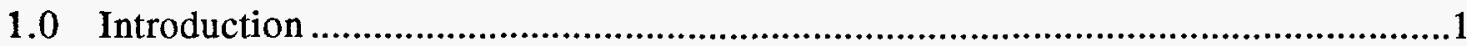

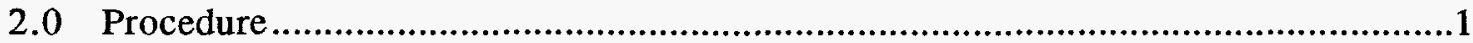

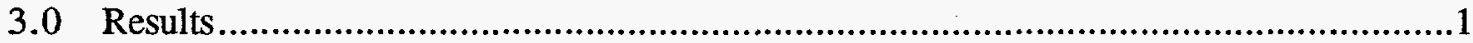

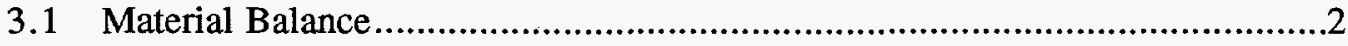

3.2 Feed Coal Analysis .................................................................................

3.2.1 SGI Development Center ............................................................2

3.2.2 Commercial Testing and Engineering Analysis................................2

3.3 Simulated PDF Analysis.................................................................................4

3.3.1 SGI Development Center .........................................................4

3.3.2 Commercial Testing and Engineering Analysis.................................4

3.4 CDL Analysis .......................................................................................4

3.4.1 SGI's Development Center, NMR Analysis ......................................

3.4.2 Commercial Testing and Engineering .........................................

3.4.3 National Institute of Occupational Safety and Health (NIOSH) ......7

4.0 Conclusions 8

Appendix I Commercial Testing and Engineering Analysis Sheets......................................11

Appendix II ${ }^{13} \mathrm{C}$ and ${ }^{1} \mathrm{H}$ NMR Spectra of CDL.......................................................12

Appendix III National Institute for Occupational Safety and Health Data Sheets...............13 


\section{TABLES}

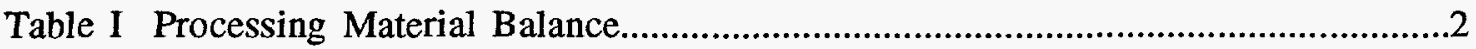

Table II SGI ASTM Proximate Analysis of Raw Coal..................................................2

Table III CTE Raw Coal Proximate and Ultimate Analysis Results......................................3

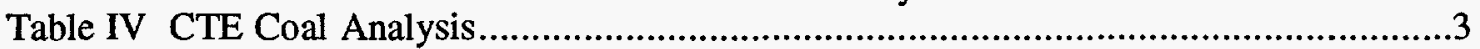

Table V SGI ASTM Proximate Analysis of Simulated PDF ...........................................4

Table VI CTE Simulated PDF Proximate and Ultimate Analysis Results........................5

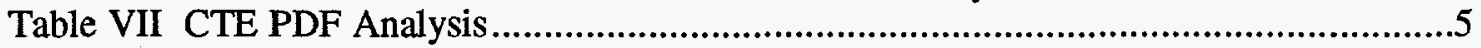

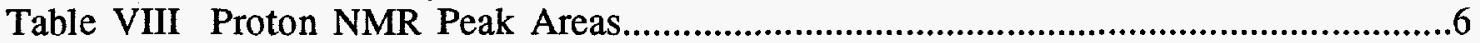

Table IX Commercial Testing and Engineering Blended CDL Analysis ...........................7

Table X Buckskin CDL Distillation Analysis.............................................................8

Table XI Buckskin Coal and PDF Sulfur Variability ................................................9

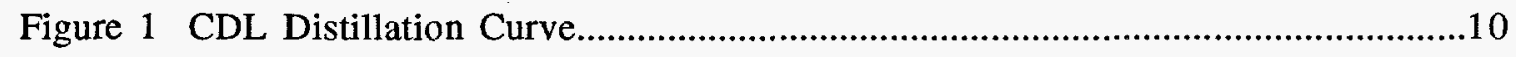




\subsection{Introduction}

The Liquids From Coal (LFC) Process, developed by SGI International, employs a mild gasification procedure to produce two co-products, a Coal Derived Liquid (CDL) and a solid Process Derived Fuel (PDF). The CDL is formed from the condensation of volatile matter removed from the coal during the LFC Process, and the PDF is the remaining solid product after most of the moisture and some of the volatile matter have been removed. In an effort to examine and classify these two mild gasification co-products, SGI Fuels, Inc. entered into an agreement with the Morgantown Energy Technology Center (METC) to produce liquid and solid co-product samples using the LFC Process on four (4) coals from three major coal resource regions in the United States. Those regions were designated to be the Powder River Basin, the Williston Basin, and Alaska. The purpose of this report is to describe the procedure of processing Buckskin coal (the Baseline coal from the Powder River Basin) to produce solid and liquid co-products and to identify the characteristics of the co-products. Buckskin coal was obtained from the Buckskin Mine located about 17 miles north of Gillette, Wyoming.

\subsection{Procedure}

Samples of coal were taken from freshly mined seam faces. Sampling started at about 10:00 AM on 4 August 1992. At the time of sampling, the sky was clear, and the temperature was about $80^{\circ} \mathrm{F}$. The samples were packaged in 55 gallon polyethylene drums with sealing lids for shipment to the SGI Development Center. After receipt of the samples at the Development. Center, the coal was prepared for processing by crushing and sizing to $-5 / 8+1 / 4$ inch. Coal samples were prepared and packaged in sealed 5 gallon plastic pails for later shipment to laboratories for analysis and testing.

The sized coal was dried in the Sample Production Unit (SPU) and then allowed to cool in sealed stainless steel containers. Once the dried coal was cool, it was stored under nitrogen in sealed 5 gallon plastic pails for later pyrolysis in the SPU.

The dried coal was pyrolyzed in the SPU and then allowed to cool in sealed stainless steel containers in the same manner as the dry coal. After the coal had cooled to about room temperature, it was spread in a thin layer on a plastic sheet to partially oxidize the char. Water was then sprayed in a fine mist to partially rehydrate the char to produce simulated PDF. The water was preweighed so that 5\% moisture would be added to the char.

During the pyrolysis runs, the CDL was collected in an electrostatic precipitator (ESP) operating at 30,000 volts in a constant current mode. To condense oil and not water, the ESP was maintained at $130^{\circ} \mathrm{F}$, above the dew point of water. The CDL was removed from the ESP by gravity and stored in sealed one liter borosilicate glass bottles.

During these standard sequences, no attempt was made to optimize the mild pyrolysis process with the heat rate, peak temperatures, or heating duration. The LFC Process, the SPU, and the ENCOAL Demonstration plant at Gillette, WY, are sufficiently flexible to produce co-products with a wide range of characteristics to meet the end users requirements.

\subsection{Results}

The coal was crushed and sized on 17 August 1992. Processing started on 19 August 1992, and sized coal was dried over a period of three (3) days. After drying, the coal was pyrolyzed starting on 24 August 1992, and the process continued for three (3) days. No difficulties. with bed pressures or equipment plugging were encountered during the procedure. 


\subsection{Material Balance.}

During these runs, a total of 313 pounds of raw coal was processed yielding 199.5 pounds of dry coal. The dry coal was pyrolyzed to yield 147.5 pounds of char and 35 pounds of CDL. Table I summarizes the material balance.

Table I Processing Material Balance

\begin{tabular}{||l|r||}
\hline \multicolumn{1}{|c|}{ Material } & \multicolumn{1}{c|}{ Total } \\
\hline Raw Coal, lbs. & 313 \\
\hline Dry Coal, lbs. & 199.5 \\
\hline Moisture (by difference), lbs & 113.5 \\
\hline Dry Feed, lbs. & 199.5 \\
\hline Char, lbs. & 147.5 \\
\hline CDL, lbs. & 35 \\
\hline $\begin{array}{l}\text { Gas and Light hydrocarbons } \\
\text { (by difference), lbs }\end{array}$ & 17 \\
\hline
\end{tabular}

\subsection{Feed Coal Analysis}

A Proximate analysis of the feed coal was conducted at the Development Center. Samples of feed coal also were sent to Commercial Testing and Engineering, Inc., for analysis.

\subsubsection{SGI Development Center}

Table II summarizes the results of the Development Center's Proximate analysis and heat of combustion determination for the feed coal.

Table II SGI ASTM Proximate Analysis of Raw Coal

\begin{tabular}{||l|r|r||}
\hline & \multicolumn{1}{|c|}{ Raw Coal } & Bone Dry Basis \\
\hline Moisture & 25.86 & -- \\
\hline Volatiles & 30.18 & 40.70 \\
\hline Fixed Carbon & 39.60 & 53.41 \\
\hline Ash & 4.37 & 5.89 \\
\hline BTU/lb & 8,610 & 11,613 \\
\hline
\end{tabular}

\subsubsection{Commercial Testing and Engineering Analysis.}

A sample of sized raw coal was sent to Commercial Testing and Engineering, Inc. in South Holland, IL, for Proximate analysis, Ultimate analysis, and associated tests to determine forms of sulfur, grindability, percent equilibrium moisture, and apparent 
specific gravity. Table III summarizes the results for the Proximate and Ultimate analysis including the heat of combustion. Data sheets for this analysis may be found in Appendix I. The sulfur content reported by CTE is much lower than average values observed for Buckskin coal but may be considered within the extreme limit of expected variability. Sulfur values for Buckskin coal range from $0.32 \%$ to $0.84 \%$, as received, as reported by CTE in tests conducted in July, 1993.

Table III CTE Raw Coal Proximate and Ultimate Analysis Results

\begin{tabular}{||l|l|r|r|}
\hline \multicolumn{1}{|c|}{ Method } & \multicolumn{1}{|c|}{ Sample } & Raw Coal & Bone Dry Basis \\
\hline D 3302 & \% Moisture & 29.62 & -- \\
\hline D 3175 & \% Volatiles & 33.40 & 47.46 \\
\hline D 3172 & \% Fixed Carbon & 32.27 & 45.85 \\
\hline D 3174 & \% Ash & 4.71 & 6.69 \\
\hline Infrared & \% Carbon & 48.40 & 68.77 \\
\hline Infrared & \% Hydrogen & 3.50 & 4.97 \\
\hline TC & \% Nitrogen & 0.77 & 1.10 \\
\hline D 4239 & \% Sulfur & 0.25 & 0.35 \\
\hline D 2015 & Heat of Combustion, BTU/lb & 8,362 & 11,881 \\
\hline
\end{tabular}

Other coal properties such as forms of sulfur, grindability, equilibrium moisture, and apparent specific gravity, as determined by CTE, are summarized in Table IV.

Table IV CTE Coal Analysis

\begin{tabular}{||l|l|c|c||}
\hline \multicolumn{1}{|c|}{ Method } & \multicolumn{1}{c|}{ Analysis } & \multicolumn{2}{c|}{ Raw Coal } \\
\hline D 2492 & Forms of Sulfur & A.R. & B.D. \\
\hline & \% Pyritic & 0.03 & 0.04 \\
\hline & \% Sulfate & 0.01 & 0.01 \\
\hline & \% Organic (diff) & 0.21 & 0.30 \\
\hline D 409 & \multicolumn{1}{|c|}{ Total } & 0.25 & 0.35 \\
\hline D 3180 & Grindability & \multicolumn{2}{|c|}{27.8} \\
\hline USX Method & \% Equilibrium $\mathrm{H}_{2} \mathrm{O}$ & \multicolumn{2}{|c|}{4} \\
\hline & USX Oxidation Index & \multicolumn{2}{|c|}{1.35} \\
\hline
\end{tabular}

Based on the December, 1992, CTE analysis, the sulfur dioxide emission for the raw coal is $0.59 \mathrm{lbs} \mathrm{SO}_{2} / \mathrm{MMBTU}$. 


\subsection{Simulated PDF Analysis}

A Proximate analysis of the simulated PDF was conducted at the Development Center. Samples of the PDF also were sent to Commercial Testing and Engineering, Inc. for analysis.

\subsubsection{SGI Development Center}

Table V summarizes the results of the Development Center's Proximate analysis and heat of combustion determination for the PDF.

Table V SGI ASTM Proximate Analysis of Simulated PDF

\begin{tabular}{||l|r|r||}
\hline & Simulated PDF & Bone Dry Basis \\
\hline Moisture & 3.13 &.- \\
\hline Volatiles & 20.41 & 21.07 \\
\hline Fixed Carbon & 68.98 & 71.21 \\
\hline Ash & 7.48 & 7.72 \\
\hline BTU/lb & 12,760 & 13,173 \\
\hline
\end{tabular}

\subsubsection{Commercial Testing and Engineering Analysis.}

A sample of simulated PDF was sent to Commercial Testing and Engineering, Inc. in South Holland, IL, for Proximate analysis, Ultimate analysis, and associated tests to determine forms of sulfur, grindability, percent equilibrium moisture, and apparent specific gravity. Table VI summarizes the results for the Proximate and Ultimate analysis including the heat of combustion. Data sheets for this analysis may be found in Appendix I. The sulfur content reported by CTE is within the level of expected variability. Sulfur values of the PDF range from $0.46 \%$ to $0.89 \%$, as received, as reported by CTE in tests conducted in July, 1993.

Other coal properties such as forms of sulfur, grindability, equilibrium moisture, and apparent specific gravity, as determined by CTE, are summarized in Table VII.

Based on CTE's analysis, the sulfur dioxide emission for the simulated PDF is $0.86 \mathrm{lbs}$ $\mathrm{SO}_{2}$ /MMBTU.

\subsection{Analysis}

The Development Center obtained ${ }^{1} \mathrm{H}$ and ${ }^{13} \mathrm{C}$ NMR spectra of the CDL. Samples of CDL also were sent to Commercial Testing and Engineering, Inc., and the National Institutes for Occupational Safety and Health for analysis. 
Table VI CTE Simulated PDF Proximate and Ultimate Analysis Results

\begin{tabular}{||l|l|r|r||}
\hline \multicolumn{1}{|c|}{ Method } & \multicolumn{1}{|c|}{ Sample } & Simulated PDF & Bone Dry Basis \\
\hline D 3302 & \% Moisture & 3.01 & -- \\
\hline D 3175 & \% Volatiles & 23.81 & 24.55 \\
\hline D 3172 & \% Fixed Carbon & 65.46 & 67.49 \\
\hline D 3174 & \% Ash & 7.72 & 7.96 \\
\hline Infrared & \% Carbon & 76.72 & 79.10 \\
\hline Infrared & \% Hydrogen & 2.94 & 3.03 \\
\hline TC & \% Nitrogen & 1.21 & 1.25 \\
\hline D 4239 & \% Sulfur & 0.54 & 0.56 \\
\hline D 2015 & Heat of Combustion, BTU/1b & 12,550 & 12,939 \\
\hline
\end{tabular}

Table VII CTE PDF Analysis

\begin{tabular}{||l|l|c|c||}
\hline \multicolumn{1}{|c|}{ Method } & \multicolumn{1}{c|}{ Analysis } & \multicolumn{2}{c|}{ PDF } \\
\hline D 2492 & Forms of Sulfur & A.R. & B.D. \\
\hline & \% Pyritic & 0.13 & 0.13 \\
\hline & \% Sulfate & 0.01 & 0.01 \\
\hline & \% Organic (diff) & 0.40 & 0.42 \\
\hline & \multicolumn{1}{|c|}{ Total } & 0.54 & 0.56 \\
\hline D 409 & Grindability & \multicolumn{2}{|c|}{44} \\
\hline D 3180 & \% Equilibrium $\mathrm{H}_{2} \mathrm{O}$ & \multicolumn{2}{|c|}{9.5} \\
\hline USX Method & USX Oxidation Index & \multicolumn{2}{|c|}{91} \\
\hline & Apparent S.G. (g/cc) & \multicolumn{2}{|c|}{1.14} \\
\hline
\end{tabular}

\subsubsection{SGI's Development Center, NMR Analysis}

NMR spectra are generally displayed on a chemical shift basis designated $\delta$ with units of ppm. Chemical shift is defined as:

$$
\delta_{i}=\frac{v_{i}-v_{T M S}}{v_{0}} \times 10^{6}
$$

where $v_{i}$ is the resonate frequency of nucleus $i, v_{0}$ is the operating frequency of the instrument, and $v_{T M S}$ is the resonate frequency of the protons (or ${ }^{13} \mathrm{C}$ nuclei) in the internal standard, tetramethylsilane. For the proton spectra, the operating frequency 
of the instrument $\left(v_{0}\right)$ is $400 \mathrm{MHz}$, and for the ${ }^{13} \mathrm{C}$ spectra, $v_{0}=101 \mathrm{MHz}$.

Reproductions of the ${ }^{1} \mathrm{H}$ and ${ }^{13} \mathrm{C}$ spectra may be found in the Appendix II.

\section{Proton $\left({ }^{1} \mathbf{H}\right)$ Spectra}

The proton NMR spectra may be divided into two general areas. At low chemical shift ( $\delta=0$ to $3 \mathrm{ppm}$ ), one finds peaks associated with protons attached to saturated carbons, and at higher chemical shift $(\delta=6$ to $8 \mathrm{ppm})$, one finds peaks associated with protons attached to aromatic carbons. The area between the saturated (or aliphatic) and the aromatic regions is occupied by peaks for protons bound to isolated carbon-carbon double bonds and protons bound directly to hetero atoms such as oxygen and nitrogen.

The major peak observed in the CDL proton spectra is a sharp signal centered at 1.25 ppm. This signal corresponds to protons bound to carbons in straight chain hydrocarbons $\left(-\mathrm{CH}_{2}-\right)$.

The CDL also shows a signal centered at $7.25 \mathrm{ppm}$. This peak is very close to that of benzene protons $(7.3 \mathrm{ppm})$, indicating the presence of monosubstituted benzene rings.

The ratios of "saturated" protons (protons bound to saturated carbon atoms) to "aromatic" protons (protons bound to aromatic carbon atoms) may be determined by integrating the area under the peaks in the appropriate regions. Table VIII summarizes these areas and the ratio of saturated to aromatic protons for Buckskin CDL.

Table VIII Proton NMR Peak Areas

\begin{tabular}{|l|r|r|r|}
\hline & \multicolumn{2}{|c|}{ AREAS } & \\
& Aromatic (A) & Saturated (S) & Ratio (S/A) \\
\hline Buckskin CDL & 21.8 & 168.8 & 7.74 \\
\hline
\end{tabular}

\section{Carbon $\left({ }^{13} \mathrm{C}\right)$ Spectra}

All of the ${ }^{13} \mathrm{C}$ spectra are proton noise decoupled. This reduces the complexity of the spectra (each carbon shows up as a singlet) and enhances the signal to noise ratio. This enhancement is important because the procedure relies on the natural abundance of ${ }^{13} \mathrm{C}$ for the NMR measurement $\left({ }^{12} \mathrm{C}\right.$ is not sensitive to the NMR experiment). The natural abundance of ${ }^{13} \mathrm{C}$ is $1.1 \%$ and its relative sensitivity is only 0.016 (proton = 1). Therefore, the ${ }^{13} \mathrm{C}$ signal is $1.2 \times 10^{-5}$ weaker than that of ${ }^{1} \mathrm{H}$. For these reasons, ${ }^{13} \mathrm{C}$ atoms which do not carry a proton have very weak signals and are usually lost in the baseline.

As in proton NMR spectra, the low chemical shift region ( $\delta=0$ to $40 \mathrm{ppm})$ is generally populated by saturated $\left(-\mathrm{CH}_{2}-\right.$, and $\left.\mathrm{CH}_{3}-\right)$ carbons, and the high chemical shift region $(\delta=110$ to $140 \mathrm{ppm})$ is populated by aromatic carbons. For ${ }^{13} \mathrm{C}$ spectra this is, however, an over simplification because ketone, aldehyde, and carboxylic acid carbons may be found at even higher chemical shifts ( $\delta=160$ to $220 \mathrm{ppm}$ ), and 
unsaturated carbons will overlap into the lower part of the aromatic region.

The major peak found in the $\mathrm{CDL}{ }^{13} \mathrm{C}$ spectra is centered at $29.6 \mathrm{ppm}$. Proton decoupling experiments show this peak to be due to methylene $\left(-\mathrm{CH}_{2}-\right)$, suggesting the presence of long chain hydrocarbons.

\subsubsection{Commercial Testing and Engineering}

A sample of the CDL was sent to Commercial Testing and Engineering's (CTE) South Holland, IL laboratory for analysis. Table IX summarizes the results of these tests. Data sheets for these analysis may be found in Appendix $I$.

Table IX Commercial Testing and Engineering Blended CDL Analysis

\begin{tabular}{||l|l|r||}
\hline \multicolumn{1}{|c|}{ Method } & \multicolumn{1}{|c|}{ Analysis } & \multicolumn{1}{c|}{ Result } \\
\hline D 287 & Specific Gravity & 1.0599 \\
\hline D 240 & Heating Value, BTU/lb & 15,555 \\
\hline D 95 & Water, wt. \% & 0.97 \\
\hline D 473 & Sediment, wt. \% & 0.19 \\
\hline D 97 & Pour Point, ${ }^{\circ}$ F & 85 \\
\hline & Cold Point, $^{\circ}$ F & 80 \\
\hline D 93 & Flash Point, ${ }^{\circ}$ F & 245 \\
\hline Infrared & \% Carbon & 77.35 \\
\hline Infrared & \% Hydrogen & 8.05 \\
\hline TC & \% Nitrogen & 0.90 \\
\hline D 1552 & \% Sulfur & 0.22 \\
\hline D 482 & \% Ash & 0.03 \\
\hline & \% Oxygen (diff.) & 12.48 \\
\hline
\end{tabular}

CTE also conducted an atmospheric distillation analysis (D 86) of the CDL sample. The results of this analysis are provided in Table $X$.

\subsubsection{National Institute for Occupational Safety and Health (NIOSH)}

Samples of CDL were submitted to NIOSH for mutagenic testing. The NIOSH sample designation for Buckskin CDL is CL210. To summarize their results, Buckskin CDL was shown to be weakly mutagenic. The NIOSH report may be found in Appendix III. 
Table X Buckskin CDL Distillation Analysis

\begin{tabular}{||l|l||}
\hline $\begin{array}{l}\text { Percent } \\
\text { Distilled }\end{array}$ & $\begin{array}{l}\text { CTE } \\
\text { Atmospheric }\end{array}$ \\
\hline IPB & 212 \\
\hline 5 & 414 \\
\hline 10 & 436 \\
\hline 20 & 454 \\
\hline 30 & 469 \\
\hline 40 & 500 \\
\hline 50 & 519 \\
\hline 60 & 566 \\
\hline 70 & 585 \\
\hline 80 & 563 \\
\hline$\%$ Recovered & 75.0 \\
\hline
\end{tabular}

\subsection{Conclusions}

The co-product production. runs conducted in August 1992 have yielded sufficient simulated PDF and CDL to meet the production needs for the Baseline Coal (Buckskin Mine). The analysis of the PDF suggests that the pyrolysis removed about $61 \%$ of the volatiles in the feed coal. This coal was very easy to process in the SPU and caused virtually no plugging of the down stream equipment.

The Buckskin coal is a low sulfur coal, containing, from the December 1992 CTE Ultimate analysis, $0.35 \%$ sulfur on a dry basis. Subsequent analyses performed by CTE in June 1993, and reflected in Table XI, resulted in a dry basis average sulfur content for Buckskin of .73\%. At the depicted levels of sulfur, the metric for the $\mathrm{SO}_{2}$ production in the coal is as little as $0.59 \mathrm{lbs} \mathrm{SO}_{2} / \mathrm{MMBTU}$. Using the average sulfur content of the June tests of Buckskin coal of $0.73 \%$ shown in Table XI, the usage metric becomes $1.26 \mathrm{lbs} \mathrm{SO}_{2} / \mathrm{MMBTU}$.

Based on the December 1992 CTE ultimate analysis results, the metric for the sulfur in Buckskin simulated PDF would produce $0.86 \mathrm{lbs}$. $\mathrm{SO}_{2} / \mathrm{MMBTU}$. Using the average sulfur content in the PDF of $0.75 \%$ as determined from the tests conducted in June 1993 by CTE and shown in Table XI, the average metric for $\mathrm{SO}_{2}$ production is $1.16 \mathrm{lbs}$. $\mathrm{SO}_{2} / \mathrm{MMBTU}$. Because of the variability of sulfur in the CTE test results, as shown in Table XI, it is not possible to make a direct correlation of the ROM coal and the simulated PDF. However, it can be generally concluded using the average values from Table XI, that the LFC Process beneficially reduces the amount of $\mathrm{SO}_{2} / \mathrm{MMBTU}$ in the simulated PDF.

The overall yield of CDL was $11 \%$ based on the raw coal and $17.5 \%$ based on dry coal. The CDL is a low sulfur co-product containing only $0.22 \%$ sulfur by weight. The distillation curve in Figure 1 shows the CDL to be a heavier oil than normal crude, but the reasonably high molar $\mathrm{H} / \mathrm{C}$ ratio of 1.28 suggests that the co-product is refinable.

The NIOSH mutagenic testing determined that the Buckskin CDL is only weakly mutagenic. 
Table XI Buckskin Coal and PDF Sulfur Variability

\begin{tabular}{|c|c|c|}
\hline Sample Date & $\begin{array}{c}\text { Buckskin Coal Sulfur } \\
\text { (dry basis) }\end{array}$ & $\begin{array}{c}\text { Buckskin PDF Sulfur } \\
\text { (dry basis) }\end{array}$ \\
\hline $12 / 2 / 92$ & $0.35 \%$ & $0.56 \%$ \\
\hline $6 / 3 / 93$ & & $0.49 \%$ \\
\hline $6 / 4 / 93$ & $0.97 \%$ & $0.96 \%$ \\
\hline $6 / 5 / 93$ & & $0.53 \%$ \\
\hline $6 / 6 / 93$ & & $0.57 \%$ \\
\hline $6 / 7 / 93$ & $0.73 \%$ & $0.74 \%$ \\
\hline $6 / 10 / 93$ & & $0.89 \%$ \\
\hline $6 / 11 / 93$ & & $0.72 \%$ \\
\hline $6 / 12 / 93$ & $0.57 \%$ & \\
\hline $6 / 12 / 93$ & $0.45 \%$ & \\
\hline $6 / 12 / 93$ & $1.15 \%$ & $0.58 \%$ \\
\hline $6 / 13 / 93$ & $0.77 \%$ & \\
\hline $6 / 13 / 93$ & $0.61 \%$ & \\
\hline $6 / 13 / 93$ & $0.56 \%$ & $1.29 \%$ \\
\hline Average of June '93 Results & $0.73 \%$ & $0.75 \%$ \\
\hline Average lbs. $\mathrm{SO}_{2} / \mathrm{MMBTU}$ & 1.26 & 1.16 \\
\hline
\end{tabular}




\section{Buckskin CDL Distillation Curve}

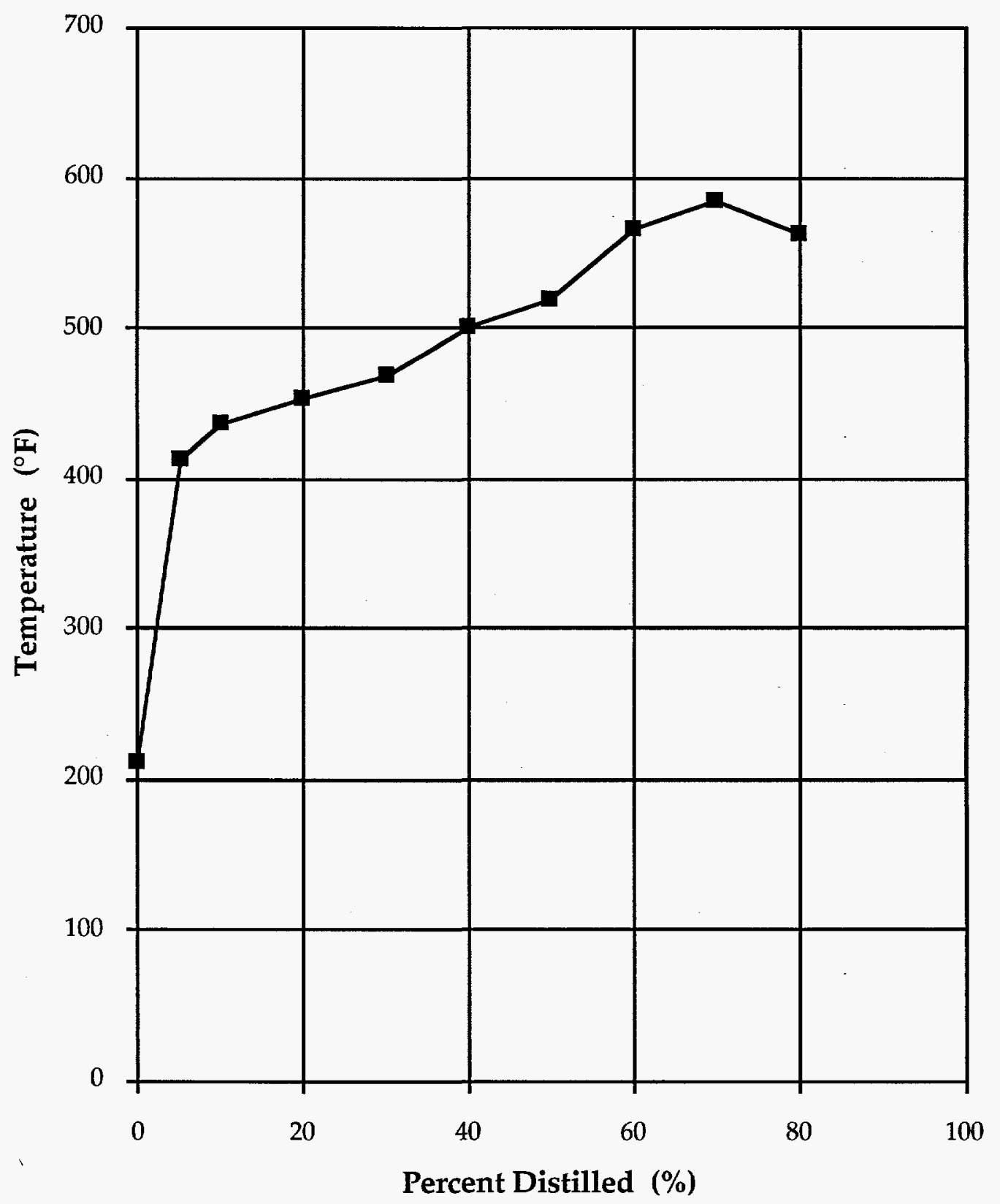

Figure 1. CDL Distillation Curve 
Appendix I Commercial Testing and Engineering Analysis Sheets 
December 2, 1992

MAUMEE RESEARCH \& ENGR., INC.

27457 Holiday Lane, Suite G

Perrysburg, OH 43551

Sample identification by

ATTN: Dr. Deane A. Home

Maumee Research \& Engr., Inc.

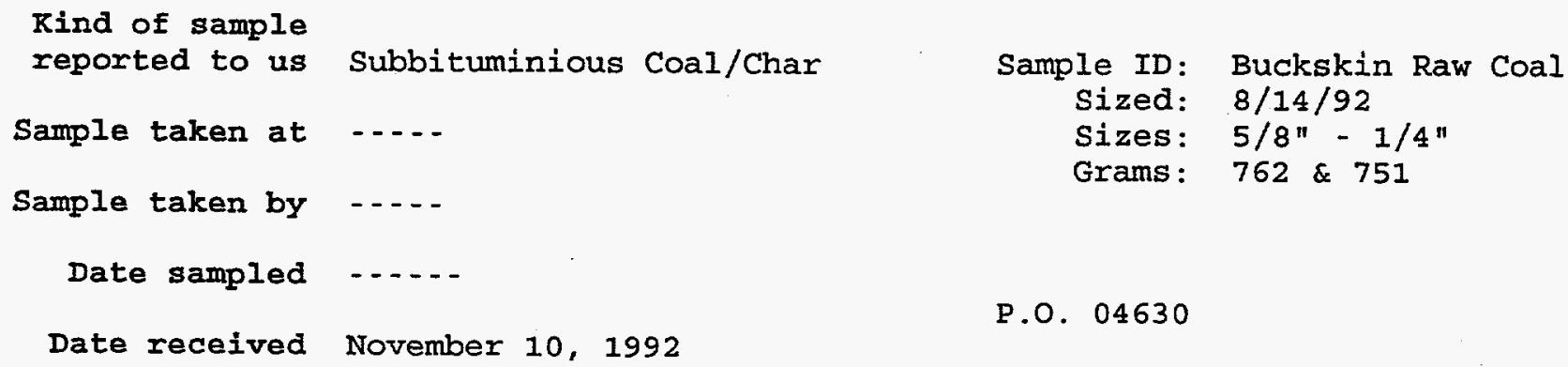

P.O. 04630

Analysis Report No. $71-45000$

Page 1 of 1

\section{PROXIMATE ANAIYSIS}

\section{As Received Dry Basis}

\& Moisture

\& Ash

\& Volatile

\% Fixed Carbon

Btu/Ib.

\& Sulfur

MAF Btu

FORMS OF SULFUR

\& Pyritic

* Sulfate

\& Organic(diff)

Total

\begin{tabular}{rr}
29.62 & $\operatorname{x\times x\times x}$ \\
4.71 & 6.69 \\
33.40 & 47.46 \\
32.27 & 45.85 \\
\hline 100.00 & 100.00
\end{tabular}

8362

0.25

11881

0.35

12733

WLTIMATE ANALYSIS 
December 2, 1992

MAUMEE RESEARCH \& ENGR., INC.

27457 Holiday Lane, Suite G

Perrysburg, $\mathrm{OH} 43551$

ATTN: Dr. Deane A. Home

Sample identification by

Maumee Research \& Engr., Inc.

Kind of sample

reported to us Subbituminious Coal/Char

Sample taken at

Sample ID:

Processed:

Buckskin Simulated PDF

Sample taken by

Date sampled .....

P.O. 04630

Date received November 10, 1992

Analysis Report No. 71-44999

Page 1 of 1

PROXIMATE ANATYSIS

As Received

\% Moisture

of Ash

\% Volatile

\& Fixed Carbon

Btu/Ib.

\& Sulfur

MAF Btu

FORMS OF SULFUR

\% Pyritic

\& Sulfate

* Organic (diff)

Total
12550

0.54

\begin{tabular}{rr}
3.01 & $x \times x \times x$ \\
7.72 & 7.96 \\
23.81 & 24.55 \\
65.46 & 67.49 \\
\hline 100.00 & 100.00
\end{tabular}

12939

0.56

14058

$x \times x$

4.55

100.00

UITIMATE ANALYSIS

\section{Dry Basis}

\% Oxygen (diff)

\& Moisture

\& Carbon

\& Hydrogen

\& Nitrogen

* Sulfur

\& Ash

As Received

\section{Dry Basis}

$\begin{array}{r}3.01 \\ 76.72 \\ 2.94 \\ 1.21 \\ 0.54 \\ 7.72 \\ 7.86 \\ \hline 100.00\end{array}$

$\times x \times x \times x$

79.10

3.03

1.25

0.56

7.96

8.10

100.00

GRINDABILITY INDEX = 44

\% EQUILLIBRIUM MOISTURE $=9.5$

OXIDATION INDEX $=91$

APPARENT SPECIFIC GRAVITY = $1.14 \mathrm{~g} / \mathrm{CC}$ $\begin{array}{ll}0.13 & 0.13 \\ 0.01 & 0.01\end{array}$

$\frac{0.40}{0.54} \quad \frac{0.42}{0.56}$ 
November 18, 1992

MAUMEE RESEARCH \& ENGR., INC.

27457 Holiday Lane, Suite G

Perrysburg, OH 43551

Sample identification by

ATTN: Dr. Deane A. Home

Maumee Research \& Engr., Inc.

\author{
Kind of sample \\ reported to us Coal Liquid \\ Sample taken at - - - - \\ Sample taken by $\ldots .$. \\ Date sampled ...... \\ Date received November 10, 1992
}

Sample ID: Coal Iiquid

Buckskin Subbituminous Coal

P.O. 04630

Analysis Report No. 71-45001

Page 1 of 3

\title{
As Received
}

$\begin{array}{lc}\text { DISTILLATION, } \\ \text { INITIAL BOI } \\ & 5 \\ & 10 \\ & 20 \\ & 30 \\ & 40 \\ & 50 \\ & 60 \\ & 70 \\ & 80 \\ & 90 \\ & 95 \\ \text { END POINT } & \\ \text { RECOVERY } & \\ \text { RESIDUE } & \\ \text { LOSS } & \end{array}$
212
414
436
454
469
500
519
566
585
563
$*$
*
75.0
25.0
0.0

* Note oil Brake, Smoke coming out.

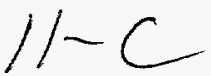


November 18, 1992

MAUMEE RESEARCH \& ENGR., INC.

27457 Holiday Lane, Suite G

Perrysburg, OH 43551

ATTN: Dr. Deane A. Home

Sample identification by

Maumee Research \& Engr., Inc.

Kind of sample

reported to us Coal Iiquid

Sample ID: Coal Liquid

Buckskin Subbituminous Coal

Sample taken at $\ldots .-$.

Sample taken by -..-

Date sampled .....-

Date received Novembex 10, 1992

P.O. 04630

Analysis Report No. 71-45001

Page 2 of 3

As Received

\section{GRAVITY}

Specific at $60 / 60^{\circ} \mathrm{F} \quad 1.0599$

Lb/gallon at $60 \% \mathrm{~F} \quad 8.828$

OAPI

2.0

HEATING VALUE

Btu/1b

15,555

Btu/gal at $600^{\circ} \quad 137,320$

WATER, \& Wt.

0.97

SEDIMENT, \& Wt.

POUR POINT, OE

0.19

$+85$

COLD POINT

$+80$

FIASHPOINT, OF

CLEVELAND OPEN CUP

$+245$

Methods: Gravity per ASTM Designation D-287-82

Heating Value per ASTM Designation D-240-87

Ash per ASTM Designation D-482-87

Water per ASTM Designation D-95-83

Pour Point per ASTM Designation D-97-87 
November 18, 1992

MAUMEE RESEARCH \& ENGR., INC.

27457 Holiday Lane, Suite G

Perrysburg, OH 43551

Sample identification by

ATTN: Dr. Deane A. Home

Maumee Research \& Engr., Inc.

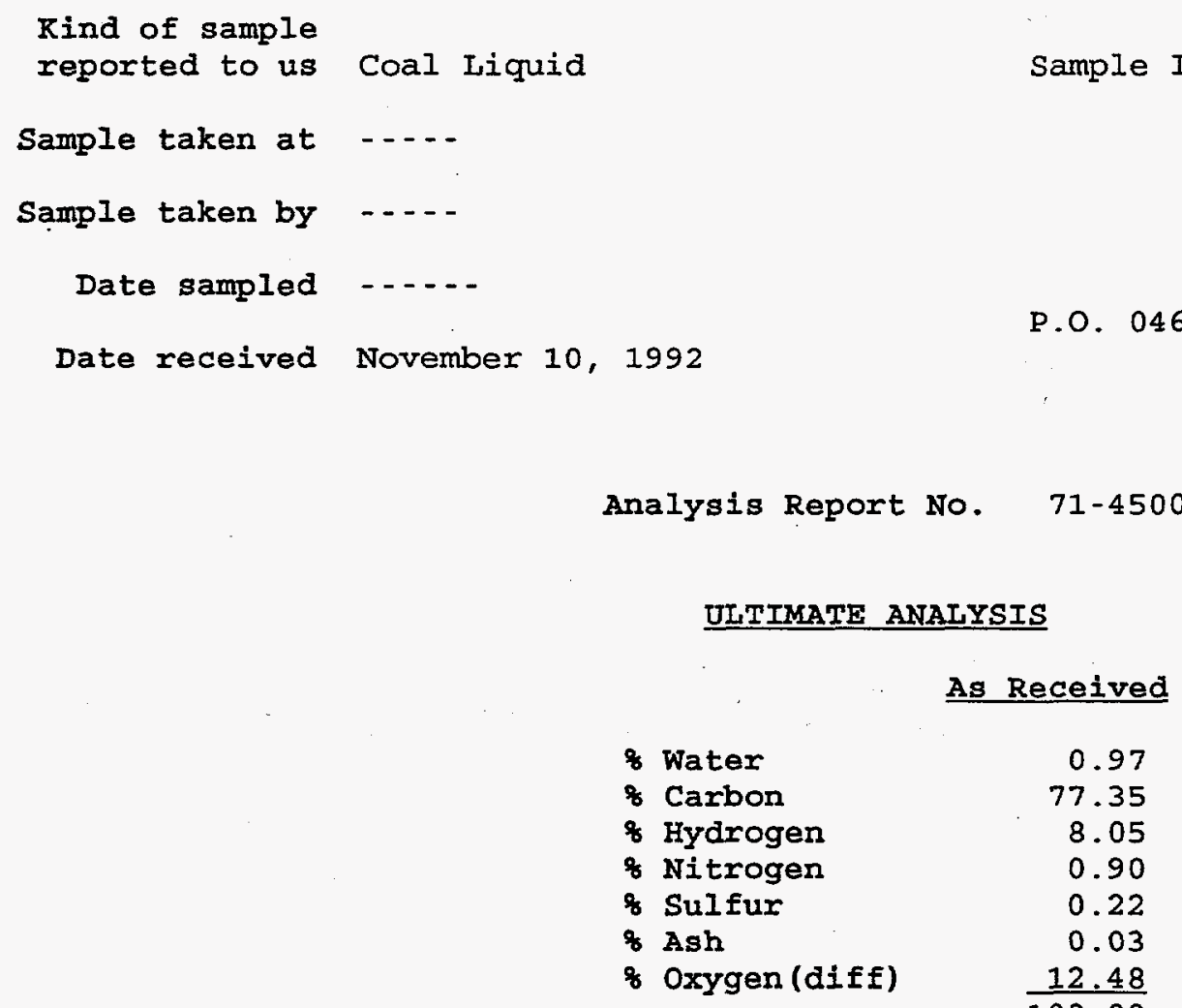

\% Water

\& Carbon

\& Hydrogen

\& Nitrogen

\& Sulfur

\% Ash

\& Oxygen (diff)

0.97

77.35

8.05

0.90

0.22

0.03

12.48

Methods: Carbon, Hydrogen and Nitrogen per LECO CHN/600 Sulfur per IECO SC-132

Ash per ASTM Designation D-482 
Appendix II ${ }^{13} \mathrm{C}$ and ${ }^{1} \mathrm{H}$ NMR Spectra of CDL 


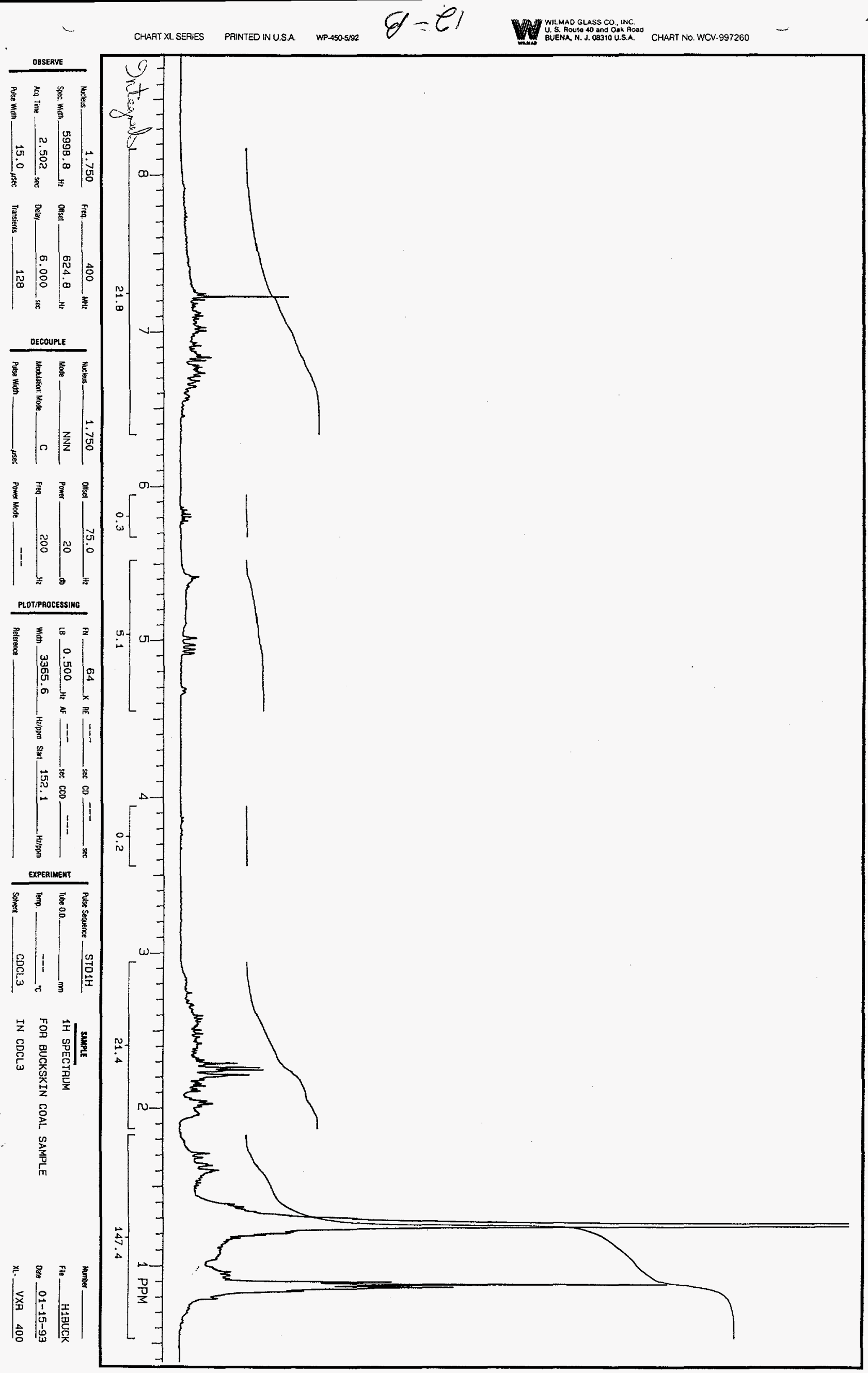


13C SPECTRUM FOA DUCKSKIN

COAL SAMPLE IN CDCL3

FILTERED BUT WITHOUT

REMOVAL OF H2O

EXP1 PULSE SEQUENCE: STD13C

DATE 01-19-93

$\begin{array}{ll}\text { SOLVENT } & \text { CDCL3 } \\ \text { FILE } & \text { C13BUC }\end{array}$

ACQUISITION DEC. \& VT

$\begin{array}{llll}\text { TN } & 13.750 & \text { DN } & 1.750\end{array}$

SW 27173.9 DO 75.0

0.552 DM YYY

30016 DMM $S$

6.0 DMF 8000

$\begin{aligned} 0 & \text { DLP } \\ 0 & \end{aligned}$

6.000 HOMO

$\mathrm{N}$

3507.4 PROCESSING

1024 SE 0.318

908 LB $\quad 1.000$

$12.5 \mathrm{FN} \quad 65536$

64 MATH

$F$

$\mathrm{N}$ DISPLAY

N SP -255.5

Y WP 27173.9

$\begin{array}{llr}N N & \text { VS } & 197 \\ N & S C & 0\end{array}$

$\begin{array}{llr}\text { ALOCK N } & \text { SC } & 0 \\ & & \text { WC }\end{array}$

IS $\quad 100$

$\begin{array}{lr}\text { RFL } & 255.5 \\ \text { RFP } & 0\end{array}$

$\begin{array}{lr}\text { RFP } & 0 \\ \text { TH } & 57 \\ \text { INS } & 1.000\end{array}$

Time for acquistion 1.65 hrs

T

${ }_{260}^{17}$

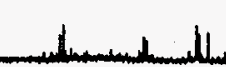


Appendix III National Institute for Occupational Safety and Health Data Sheets 
Centers for Disease Control National Institute for Occupational Safety and Health - ALOSH 944 Chestnut Ridge Road Morgantown, WV 26505-2888

November 1, 1993

Deane A. Horne, Ph.D.

Maumee Research and Engineering, Inc. 27457 Holiday Lane, Suite G

Perrysburg, OH 43551

Dear Dr. Horne,

The enclosed three reports contain the results of genotoxicity studies conducted by NIOSH on the four coal-derived 1iquid fuel samples received from Maumee Research and Engineering, Inc. (reference: Contract No. DE-AC21-91MC27240), per your request by telephone today.

Our designation of the samples is as follows:

CL201 Buckskin, Powder River Basin

MRE 1 Sarpy Creek, Rosebud Seam

MRE 2 Usibelli (Alaska)

MRE 3 Knife River, Williston Basin

If you have any questions about the reports, please let us know.

\author{
Sincerely, \\ Lusax B. Robbirs \\ Susan B. Robbins \\ Microbiology Section \\ Division of Respiratory Disease Studies
}

Encl.: Mutagenicity of CL201 in the Ames Assay

Mutagenicity of MRE 1, MRE 2, and MRE 2 in the Ames Assay

The Genotoxicity Studies of Mild Gasification Product MRE 1 in Mammalian Ce11s 


\section{Mutagenicity of CL201 in the Ames Assay}

\section{INTRODUCTION}

Mild gasification of coal is a technology being developed by the United States Department of Energy (DOE) and private industry with the hope that a cleaner method of coal use can help meet future energy needs. As the technology develops and its commercial use becomes a more viable possibility, efforts are being made to study the safety and possible toxicity of the mild gasification products. DOE and the National Institute for Occupational Safety and Health (NIOSH) are cooperating through an interagency agreement to examine some of these products for their genotoxic potential.

NIOSH has studied the mutagenicity of several mild gasification product samples using the Ames Salmonella/microsomal assay (Maron and Ames, 1983). The Ames assay is widely used as a short-term test for the detection of possible genotoxic agents and potential carcinogens. Bacterial tester strains used in the Ames assay contain specific mutations (frameshift or base pair substitution) that cause the bacteria to be dependent on growth medium containing the amino acid histidine. The mutagenic activity of a test substance is measured by the number of reverse mutations eliminating the histidine requirement. DNA mutation is generally accepted to be involved in the initiation stage of carcinogenesis; therefore, the Ames assay has often been used as the first tier of testing in the evaluation of long-term health risks associated with exposure to certain chemicals.

The assay was performed on CL201 using two solvents with quite different properties, DMSO (dimethylsulfoxide) and Tween 80 (polyoxyethylene-sorbitan mono-oleate). The two solvents were used because there has been evidence to suggest that solvent/mutagen interactions can occur during testing and cause falsely decreased or elevated mutagenic activity. Previous testing in this project has demonstrated that these interactions can occur in mild gasification products, thereby confirming the importance of testing in at least two different solvents.

\section{METHODS AND MATERIALS}

Sample description

CL201 is a mild gasification products with a liquid/tar consistency. It is a composite materials, each containing materials from a wide range of boiling points. The sample was obtained from Maumee Research and Engineering, Inc.

\section{Chemicals}

Positive controls:

2-aminoanthracene (2AA), a chemical mutagen which requires metabolic activation $(+\mathrm{S} 9)$, and trinitrofluorenone (TNF), a direct acting mutagen (-S9), were used in the assay system at final concentrations of $2.5 \mu \mathrm{g} / \mathrm{plate}$ and $0.5 \mu \mathrm{g} /$ plate, respectively. Both were purchased from Aldrich Chemical Company, Milwaukee, Wisconsin. 
Solvent control:

Dimethylsulfoxide (sterile, spectrophotometric grade) was purchased from EM Science, Cherry Hill, New Jersey.

Tween 80 (cell culture grade) was purchased from Sigma Chemical Company, St. Louis, Missouri.

\section{Sample preparation}

Tween 80 Solvation:

The sample was prepared for mutagenicity testing using methodologies similar to those described by Ma et al. (1983). Approximately $100 \mathrm{mg}$ of the sample was placed in a sterile vial; approximately $400 \mathrm{mg}$ Tween 80 was added. The mixture was heated to $50^{\circ} \mathrm{C}$ and sonicated in a Branson model 3200 water bath/sonicator for 30 minutes to facilitate homogenization. Distilled water was added dropwise $(5 \mathrm{ml})$ and the mixture was warmed, sonicated, and vortexed until a homogeneous emulsion was obtained. Distilled water was again added to the emulsion until a final sample concentration of $20 \mathrm{mg} / \mathrm{ml}$ (4\% Tween 80 ) was reached. Lower concentrations of each sample was obtained by serial dilution (using $4 \%$ Tween 80 ) of the original emulsion. The positive controls were prepared in a manner similar to the sample to ensure consistent experimental design.

\section{DMSO Solvation:}

The sample was dissolved in pure DMSO to the desired concentrations. The mixture was heated, sonicated, and vortexed in a manner similar to the Tween 80 preparation to ensure a homogeneous solution. Again, the controls were prepared the same way to ensure consistency.

\section{Ames Salmonella/microsomal Assay}

The mutagenicity of CL201 was determined using the pre-incubation variant of the Ames Salmonella/microsomal assay system (Maron and Ames, 1983), which is frequently more sensitive than the standard protocol. The sample was tested on TA98 and TA100 bacterial tester strains. Each concentration on each tester was tested with and without metabolic activation by S9, a preparation made from the livers of Aroclor 1254-treated male Wistar rats. Each of these treatments was tested in triplicate. In a test tube, $0.1 \mathrm{ml}$ of the sample or a control chemical was combined with $0.1 \mathrm{ml}$ overnight bacterial culture and $0.5 \mathrm{ml} \mathrm{S} 9$ preparation or $0.5 \mathrm{ml}$ physiological saline. Each test tube was vortexed and incubated on a rotary shaker at $37^{\circ} \mathrm{C}$ for 30 minutes prior to adding $2.5 \mathrm{ml}$ molten $\left(45^{\circ} \mathrm{C}\right)$ top agar and pouring the mixture onto a petri dish. After the top agar solidified, the dishes were inverted and incubated for 48 hours at $37^{\circ} \mathrm{C}$. The top agar contained a trace amount of histidine which is required for initial bacterial growth. After several rounds of cell division, the histidine present was depleted. Only those bacteria that had mutated to be histidineindependent continued to grow and form a colony. Those bacteria are called revertants because they have reverted (in that trait only) back to the wild-type Salmonella. The revertant colonies were scored on an automatic colony counter. The criteria for positive 
mutagenic activity in the Ames assay is a doubling of the solvent control in the number of revertants, accompanied by a dose-related increase in revertant numbers. The positive controls allow us to be certain that the bacteria grew and the $S 9$ worked properly.

\section{RESULTS AND DISCUSSION}

CL201 only displayed mutagenic activity on TA100 in the presence of S9 metabolic activation when solvated in DMSO (Table 1). The mutagenicity was extremely low, but confirmed to be significant in consequent assays. The sample also displayed mutagenic activity in TA98 at concentrations of 125 and $250 \mu \mathrm{g} /$ plate with metabolic activation (Table 1). This activity, however, could not be confirmed and therefore is not considered to be positive.

The histidine dependence in TA98 is due to a frameshift mutation, which skews the reading frame of the genetic code, while the histidine dependence in TA100 may be due to a frameshift mutation or a base-pair substitution. The reversion of either mutation requires another event of the same type mutation, so the evidence of mutagenic activity in TA100, but not in TA98 by CL201 indicates that the sample most likely contains a base-pair substitution mutagen. The fact that the activity is only present when S9 is added and not without $\mathbf{S}$ 9 suggests that the sample requires metabolic activation, in which case it is referred to as an indirect-acting mutagen.

Based on this study, it appears that CL201 is weakly mutagenic, probably inducing base-pair substitutions.

\section{REFERENCES}

Ma, C.Y., C.H. Ho, R.B. Quincy, M.R. Guerin, T.K. Rao, B.E. Allen, and J.L. Epler (1983) Preparation of oils for bacterial testing, Mutat. Res., 118:15-24.

Maron, D.M., and B.N. Ames, 1983. Revised methods for the Salmonella mutagenicity test. Mutat Res, 113:173-215. 
TABLE I

Mutagenicity Testing of CL201 in DMSO and Tween 80

\begin{tabular}{|c|c|c|c|c|c|}
\hline \multirow[b]{3}{*}{ Sample } & \multirow{3}{*}{$\begin{array}{c}\text { Concentration } \\
\mu \mathrm{g} / \mathrm{pl}\end{array}$} & \multicolumn{4}{|c|}{ Average Number of Revertant Colonies per Plate } \\
\hline & & \multicolumn{2}{|c|}{ TA 98} & \multicolumn{2}{|c|}{ TA 100} \\
\hline & & -59 & + S9 & $-\mathrm{S} 9$ & $+S 9$ \\
\hline \multirow{8}{*}{$\begin{array}{c}\text { CL201 } \\
\text { in DMSO }\end{array}$} & $0^{\mathrm{A}}$ & 26 & 46 & 112 & 102 \\
\hline & 15.6 & 24 & - B & - & - \\
\hline & 31.25 & 28 & - & 166 & - \\
\hline & 62.5 & $27^{c}$ & - & 184 & 190 \\
\hline & 125 & $28^{\mathrm{C}}$ & 94 & 103 & $208^{*}$ \\
\hline & 250 & - & 101 & 88 & $261^{*}$ \\
\hline & 500 & - & 66 & - & $214^{*}$ \\
\hline & 1000 & - & $32^{\mathrm{C}}$ & - & - \\
\hline \multirow{8}{*}{$\begin{array}{c}\text { CL201 } \\
\text { in Tween } 80\end{array}$} & $0^{\mathrm{D}}$ & 34 & 49 & 120 & 131 \\
\hline & 31.25 & 36 & - & - & - \\
\hline & 62.5 & 42 & - & 166 & - \\
\hline & 125 & 52 & - & 182 & - \\
\hline & 250 & 53 & 63 & 226 & 177 \\
\hline & 500 & - & 65 & $122^{c}$ & 189 \\
\hline & 1000 & - & 73 & - & 171 \\
\hline & 2000 & - & 54 & - & 113 \\
\hline \multirow{2}{*}{$\begin{array}{l}2 \mathrm{AA} \text { in } \\
\text { DMSO }\end{array}$} & $0^{A}$ & 26 & 46 & 112 & 102 \\
\hline & 2.5 & 32 & 1574 & 143 & 2044 \\
\hline \multirow{2}{*}{$\begin{array}{c}2 \mathrm{AA} \text { in } \\
\text { Tween } 80\end{array}$} & $0^{\mathrm{D}}$ & 34 & 49 & 120 & 131 \\
\hline & 2.5 & 47 & 297 & 151 & 427 \\
\hline
\end{tabular}

${ }^{A}$ DMSO solvent control ${ }^{\mathrm{B}}$ Not tested ${ }^{\mathrm{C}}$ Too much cytotoxicity ${ }^{\mathrm{D}}$ Tween 80 solvent control

* Positive response 


\section{APPENDIX B}

SAMPLE PRODUCTION REPORT FOR SARPY CREEK (ROSEBUD SEAM) COAL FOR "PRODUCTION OF MILD GASIFICATION CO-PRODUCTS" PROJECT

Topical Report (FINAL)

By:

D. A. Horne

J. C. Castro

December 4, 1994

Work Performed Under Contract NO.: DE-AC21-91MC27240

For:

U.S. Department of Energy

Morgantown Energy Technology Center

Morgantown, West Virginia

By:

SGI Fuels, Incorporated

La Jolla, California 


\section{EXECUTIVE SUMMARY}

Six (6) 55 gallon barrels of Sarpy Creek subbituminous coal from the Rosebud seam were sampled from the Sarpy Creek Mine located near Hardin, Montana, on 6 November 1992. These samples were crushed and sized to $-5 / 8 "+1 / 4$ " for processing in SGI's Sample Production Unit (SPU) to produce Liquids From Coal (LFC) liquid and solid co-products. A total of $564 \mathrm{lbs}$. of raw coal was processed in the SPU producing $418 \mathrm{lbs}$. of dry coal. $347 \mathrm{lbs}$. of the dry coal was processed producing 240 lbs. of simulated Process Derived Fuel (PDF) and $32.9 \mathrm{lbs}$. of Coal Derived Liquid (CDL) co-products. Testing results show that the processing upgraded the coal by removing the water from the coal (23\% by weight) and increasing its heating value from 9,212 to $12,141 \mathrm{BTU} / \mathrm{lb}$. The sulfur analysis for this coal and its resulting PDF shows a net increase in the pounds of $\mathrm{SO}_{2}$ per million BTU (0.97 and $1.67 \mathrm{lbs}$. $\mathrm{SO}_{2}$ /MMBTU for the feed coal and PDF respectively). However, closer examination of the PDF sulfur forms indicate that the ROM sample used to produce the PDF sample had more pyritic sulfur than the ROM sample tested by CTE. Since the LFC Process does not produce pyritic sulfur (it removes organic sulfur), the predicted $\mathrm{SO}_{2}$ emissions increase is artificial and caused by the inhomogeneity of the seam and samples.

The CDL has properties similar to tar sand oil with a pour point in the $95^{\circ}$ to $110^{\circ} \mathrm{F}$ range. The specific gravity of the oil is near 1.04 giving an API gravity of $4.2^{\circ}$. Most of the hydrogen compounds in the CDL are involved in paraffinic structures $\left(-\mathrm{CH}_{2}-\right)$. The $\mathrm{CDL}$ has a molar $\mathrm{H} / \mathrm{C}$ ratio of 1.29. This compares to 2.2 for simple paraffins, and 0.8 for naphthalene.

The CDL was determined to be mutagenic in the Ames test, and damaging to mamalian DNA by tests conducted at NIOSH. 


\section{TABLE OF CONTENTS}

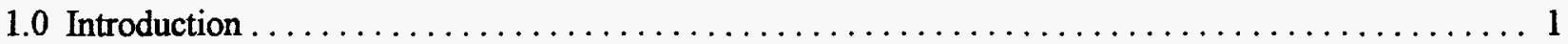

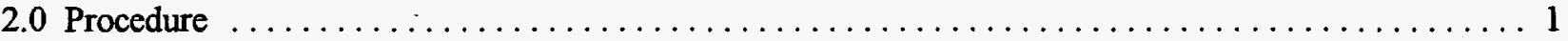

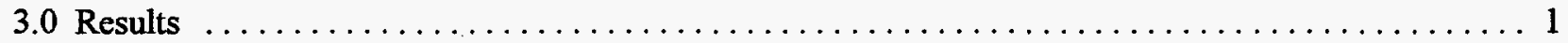

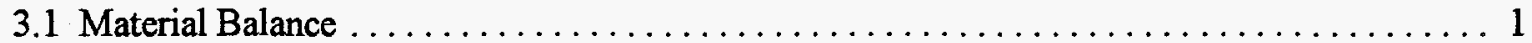

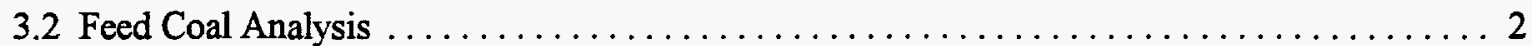

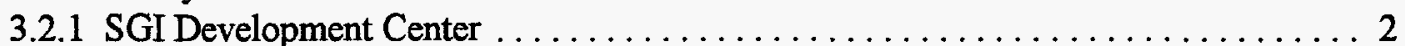

3.3.2 Commercial Testing and Engineering Analysis $\ldots \ldots \ldots \ldots \ldots \ldots \ldots \ldots \ldots$

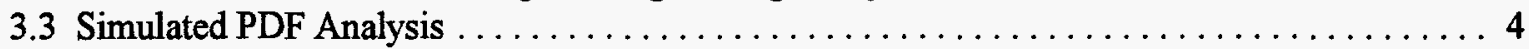

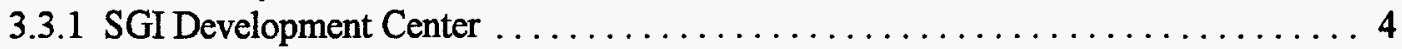

3.3.2 Commercial Testing and Engineering Analysis $\ldots \ldots \ldots \ldots \ldots \ldots \ldots \ldots$

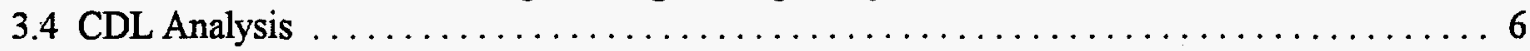

3.4.1 SGI's Development Center, NMR Analysis $\ldots \ldots \ldots \ldots \ldots \ldots \ldots \ldots \ldots \ldots$

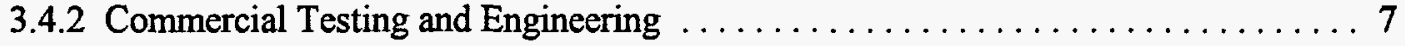

4.0 Conclusions

3.4.3 National Institute of Occupational Safety and Health (NIOSH) . . . . . . . . 8

Appendix I Commercial Testing and Engineering Analysis Sheets $\ldots \ldots \ldots \ldots \ldots \ldots \ldots \ldots \ldots \ldots 11$

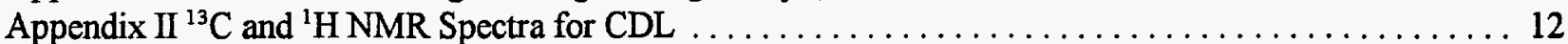

Appendix III National Institute for Occupational Safety and Health Data Sheets $\ldots \ldots \ldots \ldots \ldots \ldots 13$ 


\section{TABLES}

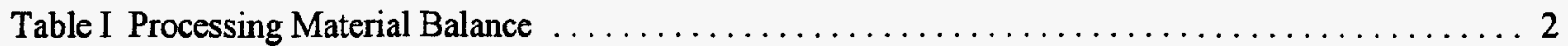

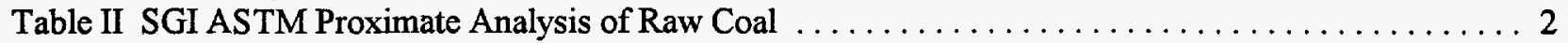

Table III CTE Raw Coal Proximate and Ultimate Analysis Results $\ldots \ldots \ldots \ldots \ldots \ldots \ldots \ldots \ldots \ldots 3$

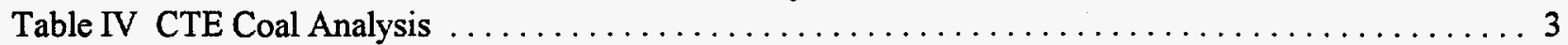

Table V SGI ASTM Proximate Analysis of Simulated PDF $\ldots \ldots \ldots \ldots \ldots \ldots \ldots \ldots \ldots \ldots \ldots$

Table VI CTE Simulated PDF Proximate and Ultimate Analysis Results $\ldots \ldots \ldots \ldots \ldots \ldots \ldots \ldots \ldots 4$

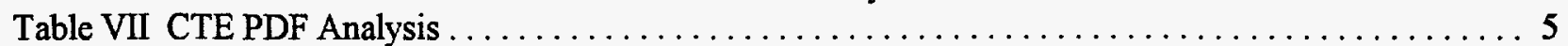

Table VIII Raw Coal and PDF Sulfur Form Comparisons $\ldots \ldots \ldots \ldots \ldots \ldots \ldots \ldots \ldots \ldots$

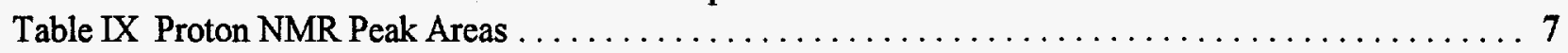

Table X Commercial Testing and Engineering Blended CDL Analysis $\ldots \ldots \ldots \ldots \ldots \ldots \ldots \ldots \ldots$

Table XI Sarpy Creek CDL Distillation Analysis $\ldots \ldots \ldots \ldots \ldots \ldots \ldots \ldots \ldots \ldots \ldots \ldots$

\section{FIGURES}

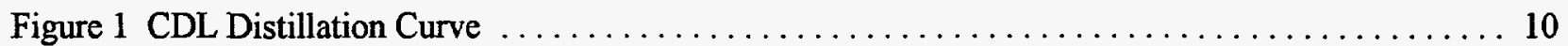




\subsection{Introduction}

The Liquids From Coal (LFC) Process, developed by SGI International, employs a mild gasification procedure to produce two co-products, a Coal Derived Liquid (CDL) and a solid Process Derived Fuel (PDF). The CDL is formed from the condensation of volatile matter removed from the coal during the LFC Process, and the PDF is the remaining solid product after most of the moisture and some of the volatile matter have been removed. In an effort to examine and classify these two mild gasification co-products, SGI Fuels, Inc. entered into an agreement with the Morgantown Energy Technology Center (METC) to produce liquid and solid co-product samples using the LFC Process on four (4) coals from three major coal resource regions in the United States. Those regions were designated to be the Powder River Basin, the Williston Basin, and Alaska. The purpose of this report is to describe the procedure of processing Sarpy Creek coal (Rosebud seam) to produce solid and liquid co-products and to identify the characteristics of the co-products. Sarpy Creek coal was obtained from the Sarpy Creek Mine located near Hardin, Montana.

\subsection{Procedure}

Samples of coal were taken from freshly mined seam faces. Sampling started at about 9:45 AM on 6 November 1992. At the time of sampling, the sky was overcast, and the temperature was about $35^{\circ} \mathrm{F}$. The samples were packaged in 55 gallon polyethylene drums with sealing lids for shipment to the SGI Development Center. After receipt of the samples at the Development Center, the coal was prepared for processing by crushing and sizing to $-5 / 8+1 / 4$ inch. Coal samples were prepared and packaged in sealed 5 gallon plastic pails for later shipment to laboratories for analysis and testing.

The sized coal was dried in the Sample Production Unit (SPU) and then allowed to cool in sealed stainless steel containers. Once the dried coal was cool, it was stored under nitrogen in sealed 5 gallon plastic pails for later pyrolysis in the SPU.

The dried coal was pyrolyzed in the SPU and then allowed to cool in sealed stainless steel containers in the same manner as the dry coal. After the coal had cooled to about room temperature, it was spread in a thin layer on a plastic sheet to partially oxidize the char. Water was then sprayed in a fine mist to partially rehydrate the char to produce simulated PDF. The water was preweighed so that $5 \%$ moisture would be added to the char.

During the pyrolysis runs, the CDL was collected in an electrostatic precipitator (ESP) operating at 30,000 volts in a constant current mode. To condense oil and not water, the ESP was maintained at $130^{\circ} \mathrm{F}$, above the dew point of water. The CDL was removed from the ESP by gravity and stored in sealed one liter borosilicate glass bottles.

During these standard sequences, no attempt was made to optimize the mild pyrolysis process with the heat rate, peak temperatures, or heating duration. The LFC Process, the SPU, and the ENCOAL Demonstration plant at Gillette, WY, are sufficiently flexible to produce co-products with a wide range of characteristics to meet the end users requirements.

\subsection{Results}

The coal was crushed and sized on 30 November 1992. Processing started on 2 December 1992, and sized coal was dried over a period of seven (7) days. After drying, the coal was pyrolyzed starting on 14 December 1992, and the process continued for six (6) days. No difficulties with bed pressures or equipment plugging were encountered during the procedure.

\subsection{Material Balance.}

During these runs, a total of 564 pounds of raw coal was processed yielding 418 pounds of 
dry coal and 9.8 pounds of fines. Not all (only 347 pounds) of the dry coal was pyrolyzed to yield 240 pounds of char, 9.9 pounds of fines and 32.9 pounds of CDL. Table I summarizes the material balance.

Table I Processing Material Balance

\begin{tabular}{|l|r||}
\hline \multicolumn{1}{|c|}{ Material } & \multicolumn{1}{c|}{ Total } \\
\hline Raw Coal, lbs. & 564 \\
\hline Dry Coal, lbs. & 418 \\
\hline Fines, lbs. & 9.8 \\
\hline Moisture (by difference), lbs & 136.2 \\
\hline Dry Feed, lbs. & 347 \\
\hline Char, lbs. & 240 \\
\hline Fines, lbs. & 9.9 \\
\hline CDL, lbs. & 32.9 \\
\hline $\begin{array}{l}\text { Gas and Light hydrocarbons } \\
\text { (by difference), lbs }\end{array}$ & 64.2 \\
\hline
\end{tabular}

\subsection{Feed Coal Analysis}

A Proximate analysis of the feed coal was conducted at the Development Center. Samples of feed coal also were sent to Commercial Testing and Engineering, Inc., for analysis.

\subsubsection{SGI Development Center}

Table II summarizes the results of the Development Center's Proximate analysis and heat of combustion determination for the feed coal.

Table II SGI ASTM Proximate Analysis of Raw Coal

\begin{tabular}{||l|r|r||}
\hline & \multicolumn{1}{|c|}{ Raw Coal } & Bone Dry Basis \\
\hline Moisture & 24.55 & -- \\
\hline Volatiles & 27.31 & 36.20 \\
\hline Fixed Carbon & 41.08 & 54.45 \\
\hline Ash & 7.06 & 9.35 \\
\hline BTU/lb & 8,664 & 11,483 \\
\hline
\end{tabular}

\subsubsection{Commercial Testing and Engineering Analysis.}

A sample of sized raw coal was sent to Commercial Testing and Engineering, Inc. in 
South Holland, $\mathrm{IL}$ for Proximate analysis, Ultimate analysis, and associated tests to determine forms of sulfur, grindability, percent equilibrium moisture, and apparent specific gravity. Table III summarizes the results for the Proximate and Ultimate analysis including the heat of combustion. Data sheets for this analysis may be found in Appendix $\mathrm{I}$.

Table III CTE Raw Coal Proximate and Ultimate Analysis Results

\begin{tabular}{||l|l|r|r||}
\hline \multicolumn{1}{|c|}{ Method } & \multicolumn{1}{|c|}{ Sample } & Raw Coal & Bone Dry Basis \\
\hline D 3302 & \% Moisture & 23.27 & -- \\
\hline D 3175 & \% Volatiles & 31.03 & 40.44 \\
\hline D 3172 & \% Fixed Carbon & 38.27 & 49.88 \\
\hline D 3174 & \% Ash & 7.43 & 9.68 \\
\hline Infrared & \% Carbon & 52.58 & 68.53 \\
\hline Infrared & \% Hydrogen & 3.77 & 4.91 \\
\hline TC & \% Nitrogen & 0.97 & 1.26 \\
\hline D 4239 & \% Sulfur & 0.45 & 0.58 \\
\hline D 2015 & Heat of Combustion, BTU/lb & 9,212 & 12,006 \\
\hline
\end{tabular}

Other coal properties such as forms of sulfur, grindability, equilibrium moisture, and apparent specific gravity, as determined by CTE, are summarized in Table IV.

Table IV CTE Coal Analysis

\begin{tabular}{||l|l|c|c||}
\hline \multicolumn{1}{|c|}{ Method } & \multicolumn{1}{|c|}{ Analysis } & \multicolumn{2}{c|}{ Raw Coal } \\
\hline D 2492 & Forms of Sulfur & A.R. & B.D. \\
\hline & \% Pyritic & 0.17 & 0.22 \\
\hline & \% Sulfate & 0.01 & 0.01 \\
\hline & \% Organic (diff) & 0.27 & 0.35 \\
\hline & \multicolumn{1}{|c|}{ Total } & 0.45 & 0.58 \\
\hline D 409 & Grindability & \multicolumn{2}{|c|}{50} \\
\hline D 3180 & \% Equilibrium $\mathrm{H}_{2} \mathrm{O}$ & \multicolumn{2}{|c|}{41.9} \\
\hline USX Method & USX Oxidation Index & \multicolumn{2}{|c|}{1.32} \\
\hline & Apparent S.G. (g/cc) & \multicolumn{2}{|c|}{} \\
\hline
\end{tabular}

Based on the CTE analysis, the sulfur dioxide emission for the raw coal is $0.97 \mathrm{lbs}$. $\mathrm{SO}_{2}$ /MMBTU. 


\subsection{Simulated PDF Analysis}

A Proximate analysis of the simulated PDF was conducted at the Development Center. Samples of the PDF also were sent to Commercial Testing and Engineering, Inc. for analysis.

\subsubsection{SGI Development Center}

Table V summarizes the results of the Development Center's Proximate analysis and heat of combustion determination for the PDF.

Table V SGI ASTM Proximate Analysis of Simulated PDF

\begin{tabular}{||l|r|r|}
\hline & Simulated PDF & Bone Dry Basis \\
\hline Moisture & 3.09 &.- \\
\hline Volatiles & 16.80 & 17.34 \\
\hline Fixed Carbon & 62.31 & 64.29 \\
\hline Ash & 17.80 & 18.37 \\
\hline BTU/bb & 11,890 & 12,269 \\
\hline
\end{tabular}

\subsubsection{Commercial Testing and Engineering Analysis..}

A sample of simulated PDF was sent to Commercial Testing and Engineering, Inc. in South Holland, IL for Proximate analysis, Ultimate analysis, and associated tests to determine forms of sulfur, grindability, percent equilibrium moisture, and apparent specific gravity. Table VI summarizes the results for the Proximate and Ultimate analysis including the heat of combustion. Data sheets for this analysis may be found in Appendix I.

Table VI CTE Simulated PDF Proximate and Ultimate Analysis Results

\begin{tabular}{||l|l|r|r||}
\hline \multicolumn{1}{|c|}{ Method } & \multicolumn{1}{|c|}{ Sample } & Simulated PDF & Bone Dry Basis \\
\hline D 3302 & \% Moisture & 2.14 & -- \\
\hline D 3175 & \% Volatiles & 20.49 & 20.94 \\
\hline D 3172 & \% Fixed Carbon & 63.70 & 65.09 \\
\hline D 3174 & \% Ash & 13.67 & 13.97 \\
\hline Infrared & \% Carbon & 71.84 & 73.41 \\
\hline Infrared & \% Hydrogen & 3.23 & 3.30 \\
\hline TC & \% Nitrogen & 1.24 & 1.27 \\
\hline D 4239 & \% Sulfur & 1.02 & 1.04 \\
\hline D 2015 & Heat of Combustion, BTU/lb & 12,141 & 12,406 \\
\hline
\end{tabular}


Other coal properties such as forms of sulfur, grindability, equilibrium moisture, and apparent specific gravity, as determined by CTE, are summarized in Table VII.

Table VII CTE PDF Analysis

\begin{tabular}{||l|l|c|c||}
\hline \multicolumn{1}{|c|}{ Method } & \multicolumn{1}{|c|}{ Analysis } & \multicolumn{2}{c|}{ PDF } \\
\hline D 2492 & Forms of Sulfur & A.R. & B.D. \\
\hline & \% Pyritic & 0.67 & 0.68 \\
\hline & \% Sulfate & 0.01 & 0.01 \\
\hline & \% Organic (diff) & 0.34 & 0.35 \\
\hline & \multicolumn{1}{|c|}{ Total } & 1.02 & 1.04 \\
\hline D 409 & Grindability & \multicolumn{2}{|c|}{48} \\
\hline D 3180 & \% Equilibrium $\mathrm{H}_{2} \mathrm{O}$ & \multicolumn{2}{|c|}{97} \\
\hline USX Method & USX Oxidation Index & \multicolumn{2}{|c|}{1.23} \\
\hline & Apparent S.G. (g/cc) & \multicolumn{2}{|c|}{} \\
\hline
\end{tabular}

Based on CTE's analysis, the sulfur dioxide emission for the simulated PDF is 1.67 lbs. $\mathrm{SO}_{2}$ /MMBTU. However, closer examination of the PDF sulfur forms indicate that the ROM sample used to produce the PDF sample had more pyritic sulfur than the ROM sample tested by CTE. As shown in Table VIII, the CTE analysis of ROM sulfur forms indicates that the $347 \mathrm{lbs}$. of raw coal would contain $0.76 \mathrm{lbs}$. of pyritic sulfur and $1.21 \mathrm{lbs}$. of organic sulfur. The CTE analysis of PDF sulfur forms indicates that the $250 \mathrm{lbs}$. of processed coal (PDF) would contain $1.70 \mathrm{lbs}$. of pyritic sulfur and $0.88 \mathrm{lbs}$. of organic sulfur. This indicates a less than expected $27 \%$ reduction of the organic sulfur and an impossible production of $0.94 \mathrm{lbs}$. of pyritic sulfur. Also shown in Table VIII, the CTE proximate analysis indicates that the 347 lbs. of raw coal would contain $173 \mathrm{lbs}$. of fixed carbon and $33.6 \mathrm{lbs}$. ash. The CTE proximate analysis indicates that the $250 \mathrm{lbs}$. of processed coal (PDF) would contain $163 \mathrm{lbs}$. of fixed carbon and $34.9 \mathrm{lbs}$. of ash, an improbable $10 \mathrm{lbs}$. decrease in fixed carbon and $1.3 \mathrm{lbs}$. increase in ash. Since the LFC Process removes volatile matter and leaves the fixed carbon and ash, these results indicate that the raw coal sample used to produce PDF contained more ash and less fixed carbon than the raw coal sample analyzed by CTE. The ash contains the pyritic sulfur forms, and therefore, the predicted $\mathrm{SO}_{2}$ emissions increase is artificial and caused by the inhomogeneity of the seam and samples. 
Table VIII Raw Coal and PDF Sulfur Form Comparisons

\begin{tabular}{||l|c|c|}
\hline \multicolumn{1}{|c|}{ Constituent } & $\begin{array}{c}\text { Projected Weight in } \\
\text { Raw Coal (lbs) }\end{array}$ & $\begin{array}{c}\text { Projected Weight in } \\
\text { PDF (lbs) }\end{array}$ \\
\hline Pyritic Sulfur & 0.76 & 1.70 \\
\hline Organic Sulfur & 1.21 & 0.88 \\
\hline Fixed Carbon & 173.1 & 162.7 \\
\hline Ash & 33.6 & 34.9 \\
\hline
\end{tabular}

\subsection{Analysis}

The Development Center obtained ${ }^{1} \mathrm{H}$ and ${ }^{13} \mathrm{C}$ NMR spectra of the CDL. Samples of CDL also were sent to Commercial Testing and Engineering, Inc., and the National Institutes for Occupational Safety and Health for analysis.

\subsubsection{SGI's Development Center, NMR Analysis}

NMR spectra are generally displayed on a chemical shift basis designated $\delta$ with units of ppm. Chemical shift is defined as:

$$
\delta_{i}=\frac{v_{i}-v_{T M S}}{v_{0}} \times 10^{6}
$$

where $v_{i}$ is the resonate frequency of nucleus $i, v_{0}$ is the operating frequency of the instrument, and $v_{\text {TMS }}$ is the resonate frequency of the protons (or ${ }^{13} \mathrm{C}$ nuclei) in the internal standard, tetramethylsilane. For the proton spectra, the operating frequency of the instrument $\left(v_{0}\right)$ is $400 \mathrm{MHz}$, and for the ${ }^{13} \mathrm{C}$ spectra, $v_{0}=101 \mathrm{MHz}$.

Reproductions of the ${ }^{1} \mathrm{H}$ and ${ }^{13} \mathrm{C}$ spectra may be found in the Appendix II.

\section{Proton (1 $\mathbf{H})$ Spectra}

The proton NMR spectra may be divided into two general areas. At low chemical shift $(\delta=0$ to $3 \mathrm{ppm})$, one finds peaks associated with protons attached to saturated carbons, and at higher chemical shift $(\delta=6$ to $8 \mathrm{ppm})$, one finds peaks associated with protons attached to aromatic carbons. The area between the saturated (or aliphatic) and the aromatic regions is occupied by peaks for protons bound to isolated carbon-carbon double bonds and protons bound directly to hetero atoms such as oxygen and nitrogen.

The major peak observed in the CDL proton spectra is a sharp signal centered at 1.25 ppm. This signal corresponds to protons bound to carbons in straight chain hydrocarbons $\left(-\mathrm{CH}_{2}-\right)$.

The CDL also shows a signal centered at $7.25 \mathrm{ppm}$. This peak is very close to that of benzene protons $(7.3 \mathrm{ppm})$, indicating the presence of monosubstituted benzene rings. 
The ratios of "saturated" protons (protons bound to saturated carbon atoms) to "aromatic" protons (protons bound to aromatic carbon atoms) may be determined by integrating the area under the peaks in the appropriate regions. Table VIII summarizes these areas and the ratio of saturated to aromatic protons for Sarpy Creek CDL.

Table IX Proton NMR Peak Areas

\begin{tabular}{||l|r|r|r||}
\hline & \multicolumn{2}{|c|}{ AREAS } & \\
& Aromatic (A) & Saturated (S) & Ratio (S/A) \\
\hline Sarpy Creek CDL & 27.0 & 104.0 & 3.85 \\
\hline
\end{tabular}

\section{Carbon $\left({ }^{13} \mathrm{C}\right)$ Spectra}

All of the ${ }^{13} \mathrm{C}$ spectra are proton noise decoupled. This reduces the complexity of the spectra (each carbon shows up as a singlet) and enhances the signal to noise ratio. This enhancement is important because the procedure relies on the natural abundance of ${ }^{13} \mathrm{C}$ for the NMR measurement $\left({ }^{12} \mathrm{C}\right.$ is not sensitive to the NMR experiment). The natural abundance of ${ }^{13} \mathrm{C}$ is $1.1 \%$ and its relative sensitivity is only 0.016 (proton = 1). Therefore, the ${ }^{13} \mathrm{C}$ signal is $1.2 \times 10^{-5}$ weaker than that of ${ }^{1} \mathrm{H}$. For these reasons, ${ }^{13} \mathrm{C}$ atoms which do not carry a proton have very weak signals and are usually lost in the baseline.

As in proton NMR spectra, the low chemical shift region ( $\delta=0$ to $40 \mathrm{ppm})$ is generally populated by saturated $\left(-\mathrm{CH}_{2}-\right.$, and $\left.\mathrm{CH}_{3}-\right)$ carbons, and the high chemical shift region $(\delta=110$ to $140 \mathrm{ppm})$ is populated by aromatic carbons. For ${ }^{13} \mathrm{C}$ spectra this is, however, an over simplification because ketone, aldehyde, and carboxylic acid carbons may be found at even higher chemical shifts $(\delta=160$ to $220 \mathrm{ppm})$, and unsaturated carbons will overlap into the lower part of the aromatic region.

The major peak found in the $\mathrm{CDL}{ }^{13} \mathrm{C}$ spectra is centered at $29.6 \mathrm{ppm}$. Proton decoupling experiments show this peak to be due to methylene $\left(-\mathrm{CH}_{2}-\right)$, suggesting the presence of long chain hydrocarbons.

\subsubsection{Commercial Testing and Engineering}

A sample of the CDL was sent to Commercial Testing and Engineering's (CTE) South Holland, IL laboratory for analysis. Table IX summarizes the results of these tests. Data sheets for these analysis may be found in Appendix $\mathbf{I}$.

CTE also conducted an atmospheric distillation analysis (D 86) of the CDL sample. The results of this analysis are provided in Table $X$. 


\subsubsection{National Institute for Occupational Safety and Health (NIOSH)}

Samples of CDL were submitted to NIOSH for mutagenic testing. The NIOSH sample designation for Sarpy Creek CDL is MRE 1. To summarize their results, Sarpy Creek CDL was shown to be mutagenic in the Ames Salomonella microsomal Assay. Genotoxicity studies for this CDL were also carried out in mammalian cells. The results of these tests indicate that Sarpy Creek CDL "can cause DNA damage, chromosome breakage, and/or spindle fiber dysfunction." The NIOSH report may be found in Appendix III.

Table X Commercial Testing and Engineering Blended CDL Analysis

\begin{tabular}{||l|l|r|}
\hline \multicolumn{1}{|c|}{ Method } & \multicolumn{1}{c|}{ Analysis } & \multicolumn{1}{c|}{ Result } \\
\hline D 287 & Specific Gravity & 1.0431 \\
\hline D 240 & Heating Value, BTU/lb & 17,631 \\
\hline D 95 & Water, wt. \% & 0.61 \\
\hline D 473 & Sediment, wt. \% $^{\prime}$ & 0.20 \\
\hline D 97 & Pour Point, $^{\circ}$ F & 95 \\
\hline & Cold Point, $^{\circ}$ F & 90 \\
\hline D 93 & Flash Point, $^{\circ}$ F & 248 \\
\hline Infrared & \% Carbon & 78.50 \\
\hline Infrared & \% Hydrogen & 8.51 \\
\hline TC & \% Nitrogen & 0.46 \\
\hline D 1552 & \% Sulfur & 0.27 \\
\hline D 482 & \% Ash & 0.01 \\
\hline & \% Oxygen (diff.) & 11.64 \\
\hline
\end{tabular}


Table XI Sarpy Creek CDL Distillation Analysis

\begin{tabular}{||l|l||}
\hline $\begin{array}{l}\text { Percent } \\
\text { Distilled }\end{array}$ & $\begin{array}{l}\text { CTE } \\
\text { Atmospheric }\end{array}$ \\
\hline IPB & 216 \\
\hline 5 & 384 \\
\hline 10 & 424 \\
\hline 20 & 462 \\
\hline 30 & 483 \\
\hline 40 & 527 \\
\hline 50 & 555 \\
\hline 60 & 550 \\
\hline$\%$ Recovered & 68.0 \\
\hline
\end{tabular}

\subsection{Conclusions}

The co-product production runs conducted in December 1992 have yielded sufficient simulated PDF and CDL to meet the production needs for the Rosebud Seam Coal (Sarpy Creek Mine). The analysis of the PDF suggests that the pyrolysis removed about $52.5 \%$ of the volatiles in the feed coal. This coal was very easy to process in the SPU and caused virtually no plugging of the down stream equipment.

The Sarpy Creek coal is a low sulfur coal and contains $0.45 \%$ sulfur on a dry basis. This coal blend would produce about $0.97 \mathrm{lbs}$. $\mathrm{SO}_{2} / \mathrm{MMBTU}$ when burned. During pyrolysis, some of the organic sulfur in the coal is removed with the volatiles, but the effective sulfur concentration remaining in the PDF increases. The Sarpy Creek PDF would produce $1.67 \mathrm{lbs} . \mathrm{SO}_{2} / \mathrm{MMBTU}$ when burned.

The overall yield of CDL was $7 \%$ based on the raw coal and $9.8 \%$ based on dry coal. The CDL is a low sulfur co-product containing only $0.28 \%$ sulfur by weight. The distillation curves shown in Figure 1 show the CDL to be a heavier oil than normal crude, but the reasonably high molar $\mathrm{H} / \mathrm{C}$ ratio of 1.29 suggests that the co-product is refinable.

The NIOSH mutagenic testing has determined that Sarpy Creek CDL is mutagenic. In addition, testing with mammalian cell cultures has shown that this CDL has the potential for causing DNA damage. 


\section{Sarpy Creek CDL Distillation Curve}

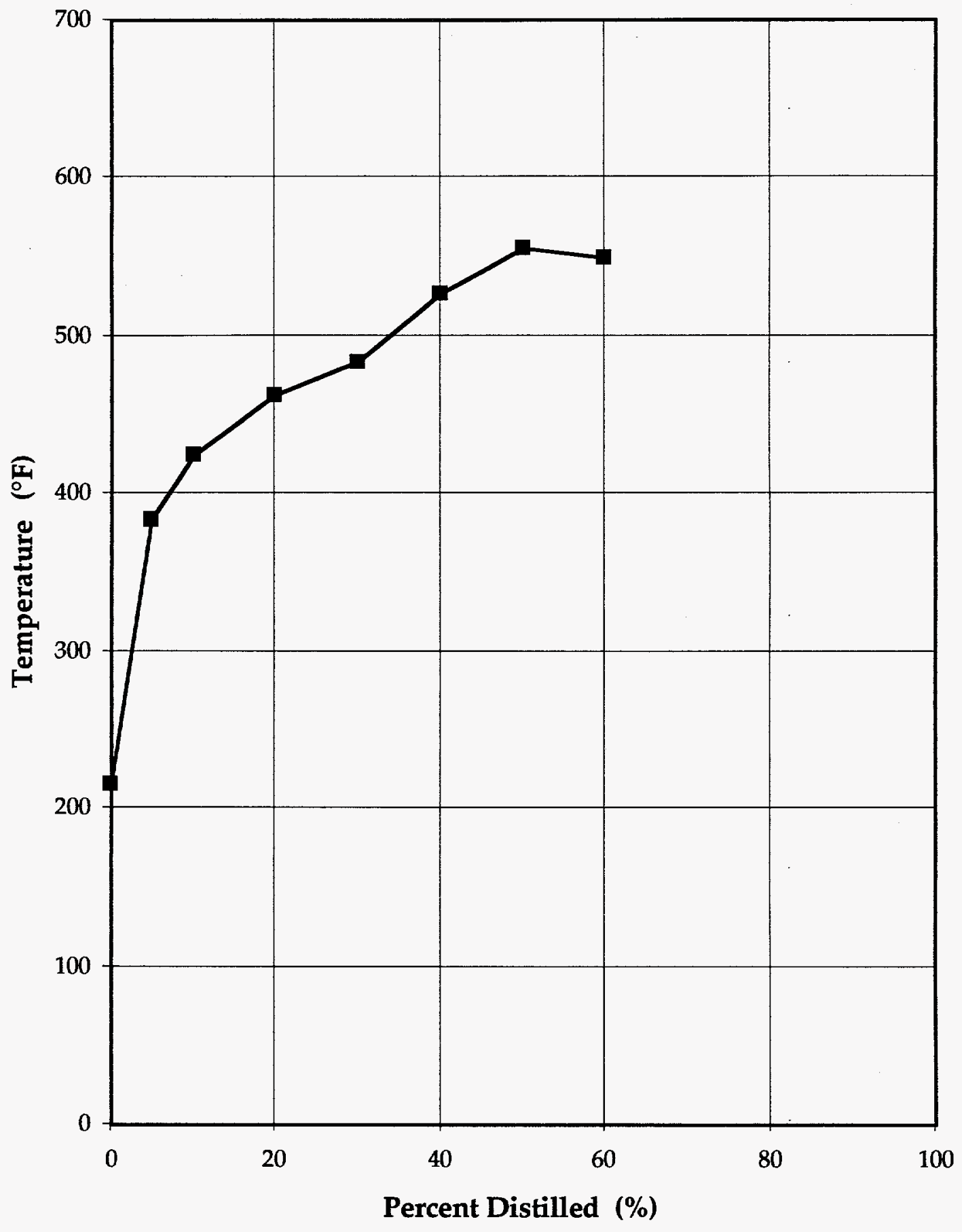

Figure 1. CDL Distillation Curve 
Appendix I Commercial Testing and Engineering Analysis Sheets 
February 2, 1993

MAUMEE RESEARCH \& ENGR., INC.

27457 Holiday Lane, Suite G

perrysburg, $\mathrm{OH} 43551$

Sample identification by

ATTN: Dr. Deane A. Home

Maumee Research \& Engr., Inc.

Kind of sample

reported to us Coal

Sample ID: Sarpy Creek Coal

Sample taken at

Sample taken by

Date sampled -....

P.O. 04689

Date received January 25, 1993

Analysis Report No. $71-49103$

Page 1 of 2

PROXIMATE ANALYSIS

As Received

\% Moisture

is As

\& Volatile

\& Fixed Carbon

$$
\begin{aligned}
& \text { Btu/1b } \\
& \text { \& Sulfur } \\
& \text { MAF Btu }
\end{aligned}
$$

FORMS OF SULPUR

$\begin{array}{rrr}\text { \& Pyritic } & 0.17 & 0.22 \\ \text { \& Sulfate } & 0.01 & 0.01 \\ \text { \& Organic(diff) } & 0.27 & 0.35 \\ \text { Total } & 0.45 & 0.58\end{array}$

ULTIMATE ANALYSIS
Dry Basis

$$
\begin{array}{r}
x \times x \times \\
9.68 \\
40.44 \\
49.88 \\
\hline 100.00
\end{array}
$$

$\frac{38.27}{100.00}$

9212

0.45

0.58

13293
As Received

\% Moisture * Carbon

* Hydrogen

* Nitrogen

\& Sulfur

$\begin{array}{rr}\text { \& Ash } & 7.43 \\ \text { \& Oxygen (diff) } & \frac{11.53}{100.00}\end{array}$

$\begin{array}{lr}\text { \& Ash } & 7.43 \\ \text { * Oxygen (diff) } & \frac{11.53}{100.00}\end{array}$

23.27

52.58

3.77

0.97

0.45

7.43

$\frac{11.53}{100.00}$
Dry Basis

$\times \times \times \times x$

68.53

4.91

1.26

0.58

9.68

15.04
GRINDABILITY INDEX $=50$

\& EQUILLIBRIUM MOISTURE = 21.9

OXIDATION INDEX = 4

APPARENT SPECIFIC GRAVITY = 1.32 
February 2, 1993

MAUMEE RESEARCH \& ENGR., INC.

27457 Holiday Lane, Suite G Perrysburg, OH 43551

ATTN: Dr. Deane A. Home

Sample identification by

Maumee Research \& Engr., Inc.

Kind of sample

reported to us Coal

Sample ID: Sarpy Creek Coal

Sample taken at

Sample taken by

Date sampled .....

P. O. 04689

Date received January 25, 1993

\author{
Analysis Report No. 71-49103
}

Page

2 of

2

METHODS: MOisture per ASTM Designation D 3173.

Ash per ASTM Designation D 3174 .

Volatile per ASTM Designation D 3175.

Btu per ASTM Designation D 2015 or 3286 .

Sulfur per ASTM Designation D 4239 (Method C)

Fixed Carbon (Calculated Value) is the resultant

of the summation of percentage moisture, ash, and

volatile matter subtracted from 100.

Hardgrove Grindability Index per ASTM Designation D 409.

Carbon, Hydrogen, and Nitrogen per LECO 600 CHN Determinator.

Forms of Sulfur per ASTM Designation D 2492.

Oxidation Test determined by USX Method.

Equilibrium Moisture per ASTM Designation D 3180.

$11-B$ 
February 2, 1993

MAUMME RESEARCH \& ENGR., INC.

27457 Holiday Lane, Suite G

Perrysburg, OH 43551

ATTN: Dr. Deane A. Home

Sample identification by

Maumee Research \& Engr., Inc.

Kind of sample

reported to us $\mathrm{Coal}$

Sample ID: Sarpy Creek

Simulated PDF Coal Char

Sample taken at

Sample taken by

Date sampled .....

P.0. 04689

Date received January 25, 1993

Analysis Report No. 71-49102

Page 1 of 2

\section{PROXIMATE ANALYSIS}

As Received

Dry Basis

\& Moisture

of Ash

\& Volatile

\& Fixed Carbon

$\mathrm{Btu} / \mathrm{Ib}$

\& Sulfur

MAF Btu

FORMS OF SULFUR

\& Pyritic

\& Sulfate

\& Organic (diff)

Total

$$
\begin{array}{r}
2.14 \\
13.67 \\
20.49 \\
63.70 \\
\hline 100.00
\end{array}
$$

12141

1.02$$
1.02
$$

$$
\begin{array}{r}
x x x x x \\
13.97 \\
20.94 \\
65.09 \\
\hline 100.00
\end{array}
$$

12406

1.04

14421

\section{ULTIMATE ANALYSIS}

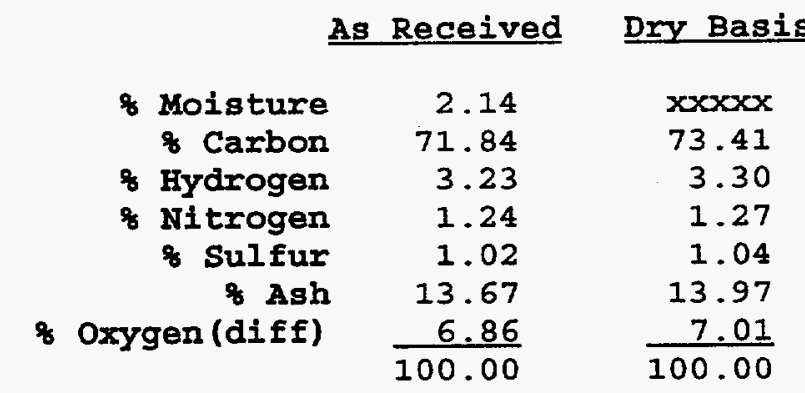

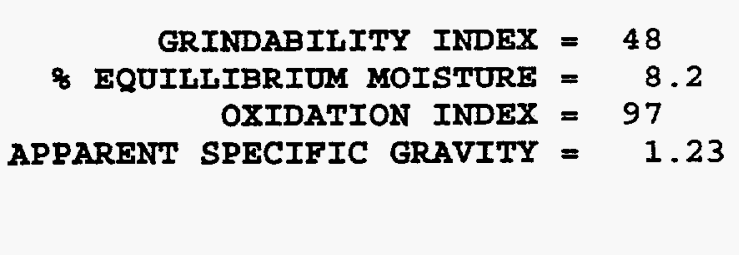


February 2, 1993

MAUMEE RESEARCH \& ENGR., INC.

27457 Holiday Lane, Suite G Perrysburg, OH 43551

ATTN: Dr. Deane A. Home

Sample identification by

Maumee Research \& Engr., Inc.

Kind of sample

reported to us Coal

Sample ID: Sarpy Creek

Simulated PDF Coal Char

Sample taken at

Sample taken by

Date sampled

$-\cdots$

P.O. 04689

Date received January 25, 1993

Analysis Report No. 71-49102

Page 2 of 2

METHODS: MOisture per ASTM Designation D 3173.

Ash per ASTM Designation D 3174.

Volatile per ASTM Designation D 3175.

Btu per ASTM Designation D 2015 or 3286 .

Sulfur per ASTM Designation D 4239 (Method C)

Fixed Carbon (Calculated Value) is the resultant

of the summation of percentage moisture, ash, and

volatile matter subtracted from 100.

Hardgrove Grindability Index per ASTM Designation D 409.

Carbon, Hydrogen, and Nitrogen per LECO 600 CHN Determinator.

Forms of Sulfur per ASTM Designation D 2492.

Oxidation Test determined by USX Method.

Equilibrium Moisture per ASTM Designation D 3180 . 
February 10, 1993

MAUMEE RESEARCH \& ENGR., INC.

27457 Holiday Lane, Suite G

Perrysburg, OH 43551

Sample identification by

ATTN: Dr. Deane A. Home

Maumee Research \& Engr., Inc.

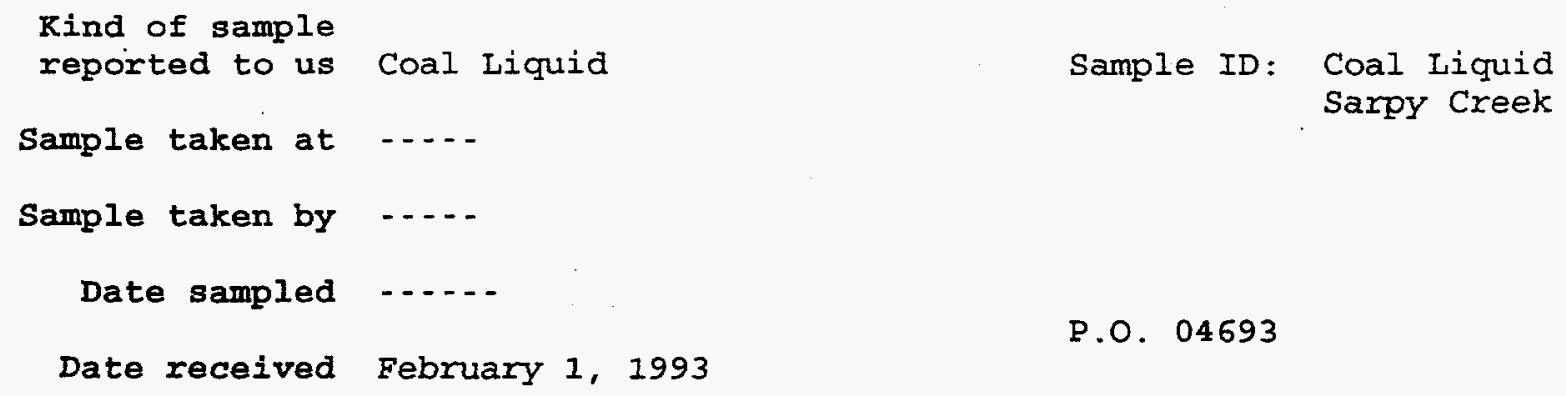

As Received

\begin{tabular}{lcc} 
DISTILIATION, & \\
\multicolumn{1}{c}{ INITIAL BOILING POINT, 8} & 216 \\
& 5 & 384 \\
& 10 & 424 \\
& 20 & 462 \\
& 30 & 483 \\
& 40 & 527 \\
& 50 & 555 \\
& 60 & 550 \\
& 70 & $\star$ \\
& 80 & $\star$ \\
END POINT & 90 & $\star$ \\
RECOVERY & 95 & $\star$ \\
RESIDUE & & $*$ \\
LOSS & & 68.0 \\
& & 17.0 \\
& & 0.0
\end{tabular}

METHOD: Distillation per ASTM Designation D 86

* NOTE: Drop in Temperature, Smoke coming out. 
February 10, 1993

MAUTMEE RESEARCH \& ENGR., INC.

27457 Holiday Lane, Suite $G$

Perrysburg, OH 43551

ATTN: Dr. Deane A. Home

Sample identification by

Maumee Research \& Engr., Inc.

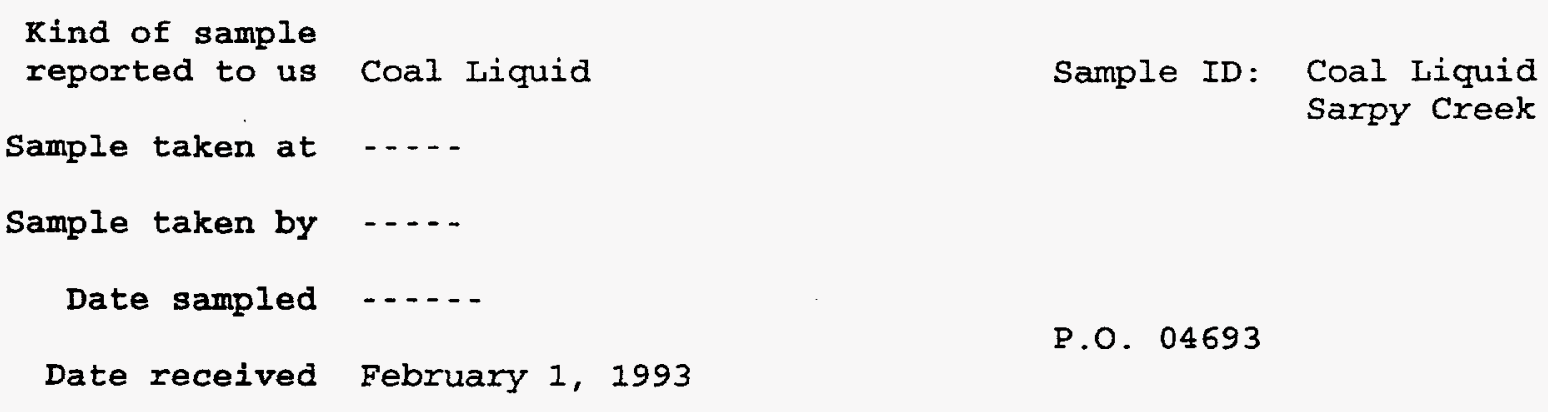

Analysis Report No. 71-49499

Page 2 of 3

\begin{tabular}{lr} 
GRAVITY & As Received \\
\cline { 2 - 2 } Specific at $60 / 60^{\circ} \mathrm{F}$ & 1.0431 \\
Ib/gallon at $60_{\mathrm{F}}$ & 8.690 \\
HEATING VAIUE & 17,631 \\
Btu/Ib & 152,213 \\
Btu/gal at 600F & 0.20 \\
SEDIMENT, \& Wt. & +95 \\
POUR POINT, OF & +90 \\
COID POINT & \\
FLASHPOINT, OF & 248 \\
CLEVILAND OPEN CUP &
\end{tabular}

Methods: Gravity per ASTM Designation D-287-82

Heating Value per ASTM Designation D-240-87

Ash per ASTM Designation D-482-87

Water per ASTM Designation D-95-83

Pour Point per ASTM Designation D-97-87 
February 10, 1993

MAUMEE RESEARCH \& ENGR., INC.

27457 Holiday Lane, Suite G

Perrysburg, OH 43551

Sample identification by

ATTN: Dr. Deane A. Home

Maumee Research \& Engr., Inc.

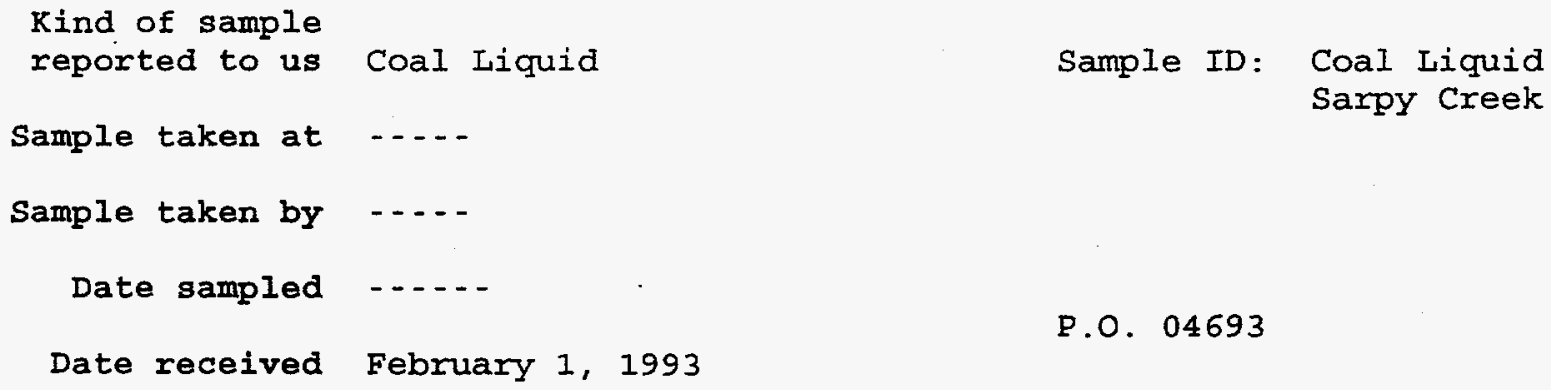

Analysis Report No. 71-49499

\section{ULTIMATE ANALYSIS}

As Received
\& Water
\& Carbon
\&ydrogen
\& Nitrogen
\& Sulfur
of Ash
\& Oxygen (diff)

$$
\begin{array}{r}
0.61 \\
78.50 \\
8.51 \\
0.46 \\
0.27 \\
0.01 \\
11.64 \\
\hline 100.00
\end{array}
$$

Methods: Carbon, Hydrogen by Infra-red Detection and Nitrogen by Thermal - conductivity. Sulfur per ASTM Designation D 1552

Ash per ASTM Designation D-482 
Appendix II ${ }^{13} \mathrm{C}$ and ${ }^{1} \mathrm{H}$ NMR Spectra of CDL 


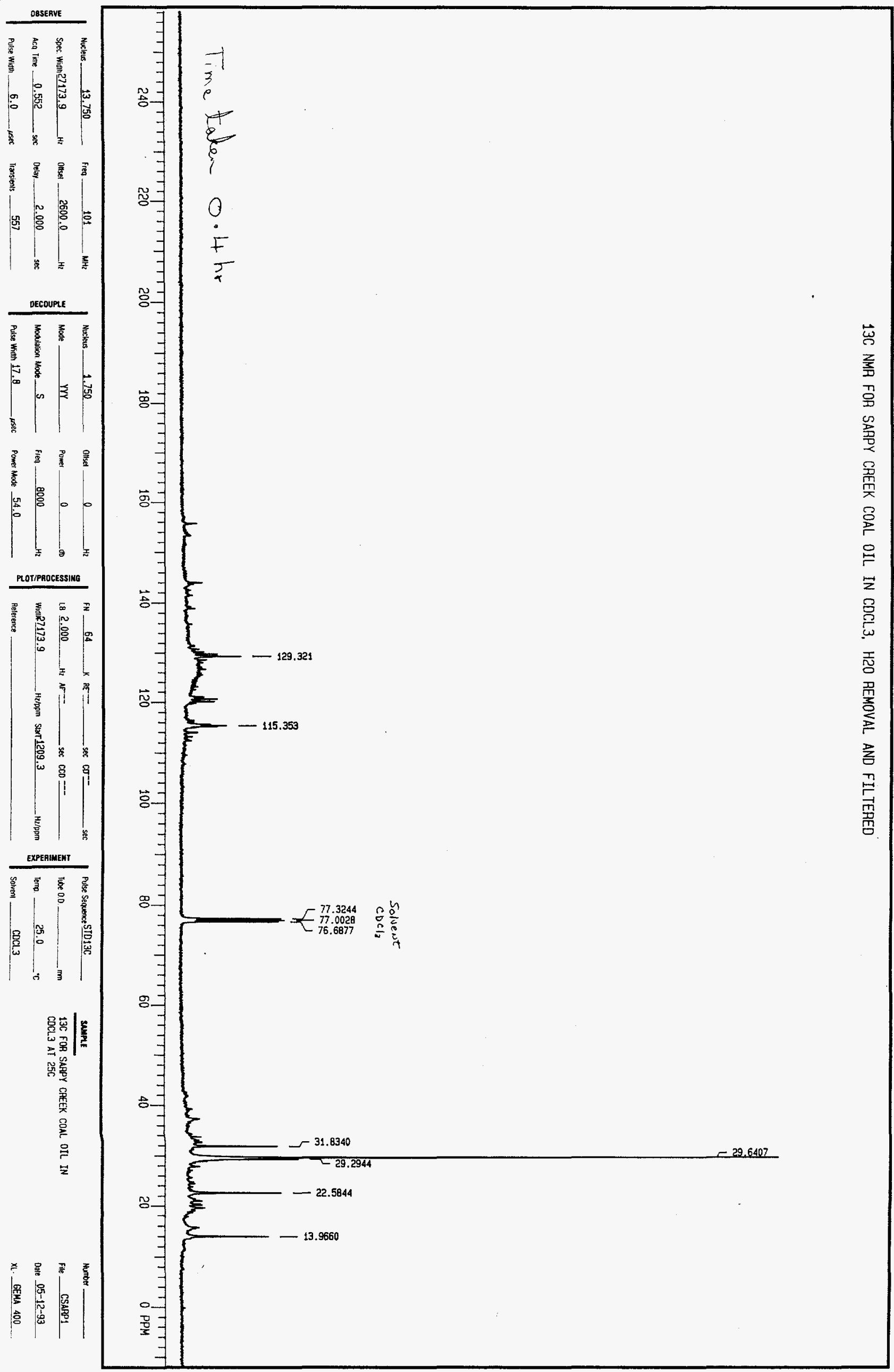


Appendix III National Institute for Occupational Safety and Health Data Sheets 
Centers for Disease Control National Institute for Occupational Safety and Health - ALOSH

944 Chestnut Ridge Road

Morgantown, WV 26505-2888

November 1, 1993

Deane A. Horne, Ph.D.

Maumee Research and Engineering, Inc.

27457 Holiday Lane, Suite G

Perrysburg, OH 43551

Dear Dr. Horne,

The enclosed three reports contain the results of genotoxicity studies conducted by NIOSH on the four coal-derived liquid fuel samples received from Maumee Research and Engineering, Inc. (reference: Contract No. DE-AC21-91MC27240), per your request by telephone today.

Our designation of the samples is as follows:

CL201 Buckskin, Powder River Basin

MRE 1 Sarpy Creek, Rosebud Seam

MRE 2 Usibelli (Alaska)

MRE 3 Knife River, Williston Basin

If you have any questions about the reports, please let us know.

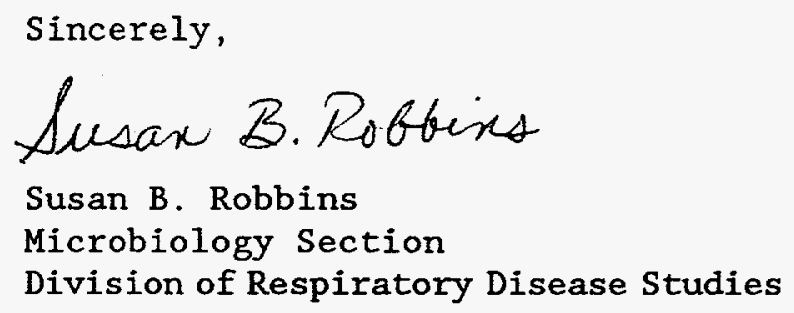

Enc1.: Mutagenicity of CL201 in the Ames Assay

Mutagenicity of MRE 1, MRE 2, and MRE 2 in the Ames Assay

The Genotoxicity Studies of Mild Gasification Product MRE 1 in Mammalian Cells 
Mutagenicity of MRE 1, MRE 2, and MRE 3 in the Ames Assay

\section{INTRODUCTION}

Mild gasification of coal is a technology being developed by the United States Department of Energy (DOE) and private industry with the hope that a cleaner method of coal use can help meet future energy needs. As the technology develops and its commercial use becomes a more viable possibility, efforts are being made to study the safety and possible toxicity of the mild gasification products. DOE and the National Institute for Occupational Safety and Health (NIOSH) are cooperating through an interagency agreement to examine some of these products for their genotoxic potential.

NIOSH has studied the mutagenicity of several mild gasification product samples using the Ames Salmonella microsomal assay (Maron and Ames, 1983). The Ames assay is widely used as a short-term test for the detection of possible genotoxic agents and potential carcinogens. Bacterial tester strains used in the Ames assay contain specific mutations (frameshift or base pair substitution) that cause the bacteria to be dependent on growth medium containing the amino acid histidine. The mutagenic activity of a test substance is measured by the number of reverse mutations eliminating the histidine requirement. Mutation is generally accepted to be involved in the initiation stage of carcinogenesis; therefore, the Ames assay has often been used as the first tier of testing in the evaluation of long-term health risks associated with exposure to certain chemicals.

\section{METHODS AND MATERIALS}

\section{Sample description}

MRE 1 has a liquid/tar consistency and a boiling point of $216^{\circ} \mathrm{F}$. The sample was made from a 50:50 mix of low- and high-sodium Montana coal and obtained from Maumee Research and Engineering, Inc. (MRE).

MRE 2 has a liquid/tar consistency, with a boiling point of $212^{\circ} \mathrm{F}$. It was made from Alaskan coal and obtained from MRE.

MRE 3 also has a liquid/tar consistency, with a boiling point of $212^{\circ} \mathrm{F}$. The sample was made from North Dakota lignite coal and obtained from MRE.

\section{Chemicals}

Positive controls:

2-aminoanthracene (2AA), a chemical mutagen which requires metabolic activation (+S9), and trinitrofluorenone (TNF), a direct acting mutagen (-S9), were used in the assay system at final concentrations of $2.5 \mu \mathrm{g} /$ plate and $0.4 \mu \mathrm{g} /$ plate, respectively. Both were purchased from Aldrich Chemical Company, Milwaukee, Wisconsin. 
Solvent control:

Dimethylsulfoxide (sterile, spectrophotometric grade) was purchased from EM Science, Cherry Hill, New Jersey.

Sample preparation

The sample was dissolved in DMSO to the desired concentrations, using methodologies similar to those described by $\mathrm{Ma}$ et al. (1983). The mixture was heated to $50^{\circ} \mathrm{C}$ and sonicated in a Branson model 3200 water bath/sonicator for 30 minutes to facilitate homogenization. The mixture was warmed, sonicated, and vortexed until a homogeneous solution was obtained. Lower concentrations of each sample was obtained by serial dilution of the original solution. The positive controls were prepared in a manner similar to the sample to ensure consistent experimental design.

\section{Ames Salmonella microsomal Assay}

The mutagenicity of each sample was determined using the pre-incubation variant of the Ames Salmonella microsomal assay system (Maron and Ames, 1983), which is frequently more sensitive than the standard protocol. The sample was tested on TA98 and TA100 bacterial tester strains. Each concentration on each tester was tested with and without metabolic activation by S9, a preparation made from the livers of Aroclor 1254-treated male Wistar rats. Each of these treatments was tested in triplicate. In a test tube, $0.1 \mathrm{ml}$ of the sample or a control chemical was combined with $0.1 \mathrm{ml}$ overnight bacterial culture and 0.5 $\mathrm{ml}$ S9 preparation or $0.5 \mathrm{ml}$ physiological saline. Each test tube was vortexed and incubated on a rotary shaker at $37^{\circ} \mathrm{C}$ for 30 minutes prior to adding $2.5 \mathrm{ml}$ molten $\left(45^{\circ} \mathrm{C}\right)$ top agar and pouring the mixture onto a petri dish. After the top agar solidified, the dishes were inverted and incubated for 48 hours at $37^{\circ} \mathrm{C}$. The top agar contained a trace amount of histidine which is required for initial bacterial growth. After several rounds of cell division, the histidine present was depleted. Only those bacteria that had mutated to be histidineindependent continued to grow and form a colony. Those bacteria are called revertants because they have reverted (in that trait only) back to the wild-type Salmonella. The revertant colonies were scored on an automatic colony counter. The criteria for positive mutagenic activity in the Ames assay is a doubling of the solvent control in the number of revertants, accompanied by a dose-related increase in revertant numbers. The positive controls allow us to be certain that the bacteria grew and the S9 worked properly.

\section{RESULTS AND DISCUSSION}

MRE 1 displayed consistant, reproducable mutagenic activity in TA98 in the presence of S9 metabolic activation. The number of revertant colonies was three to four fold higher than that of the solvent control. The sample also displayed some doubling of the solvent control in TA100 with S9 (Table 1), but that activity could not be confirmed and therefore is not considered to be positive. MRE 2 and MRE 3 also displayed some doubling of the solvent 
control activity on TA98 with S9, but less so than MRE 1. The dose-response in those two samples was less obvious as well as inconsistent.

The histidine dependence in TA98 is due to a frameshift mutation, which skews the reading frame of the genetic code, while the histidine dependence in TA100 may be due to a frameshift mutation or a base-pair substitution. The reversion of either mutation requires another event of the same type mutation, so the evidence of mutagenic activity in TA98, and less so in TA100 indicates that the samples most likely contain frameshift mutagens. The fact that the activity is only present when S9 is added and not without S9 indicates that the samples require metabolic activation, in which case mutagens present are referred to as indirect-acting mutagens.

Based on this study, it appears that MRE 1 is mutagenic, probably inducing frameshift mutations after metabolic activation. MRE 2 and MRE 3 are weakly mutagenic, most likely containing indirect-acting frameshift mutagens.

\section{REFERENCES}

Ma, C.Y., C.H. Ho, R.B. Quincy, M.R. Guerin, T.K. Rao, B.E. Allen, and J.L. Epler (1983) Preparation of oils for bacterial testing, Mutat. Res., 118:15-24.

Maron, D.M., and B.N. Ames, 1983. Revised methods for the Salmonella mutagenicity test. Mutat Res, 113:173-215. 
TABLE I

Mutagenicity Testing of MRE 1, MRE 2, and MRE 3

\begin{tabular}{|c|c|c|c|c|c|}
\hline \multirow[b]{3}{*}{ Sample } & \multirow{3}{*}{$\begin{array}{l}\text { Concentration } \\
\mu \mathrm{g} / \text { plate }\end{array}$} & \multicolumn{4}{|c|}{ Average Number of Revertant Colonies per Plate } \\
\hline & & \multicolumn{2}{|c|}{ TA 98} & \multicolumn{2}{|c|}{ TA 100} \\
\hline & & - S9 & $+\mathrm{S} 9$ & -59 & +59 \\
\hline \multirow[t]{7}{*}{ MRE 1} & $0^{\mathrm{A}}$ & 22 & 28 & 86 & 102 \\
\hline & 15.6 & 37 & B & - & - \\
\hline & 31.25 & 36 & $76^{*}$ & 135 & 167 \\
\hline & 62.5 & 30 & $96^{*}$ & 151 & 169 \\
\hline & 125 & $19^{\mathrm{C}}$ & $96^{*}$ & 129 & 222 \\
\hline & 250 & - & $101^{*}$ & $46^{\mathrm{C}}$ & 211 \\
\hline & 500 & - & - & - & 140 \\
\hline \multirow{7}{*}{ MRE 2} & $0^{A}$ & 22 & 28 & 86 & 102 \\
\hline & 31.25 & 33 & 41 & - & - \\
\hline & 62.5 & 33 & $66^{*}$ & 109 & - \\
\hline & 125 & 28 & $58^{*}$ & 141 & 168 \\
\hline & 250 & $19^{c}$ & 54 & $89^{c}$ & 161 \\
\hline & 500 & - & 47 & $50^{c}$ & 188 \\
\hline & 1000 & - & - & - & 113 \\
\hline \multirow[t]{7}{*}{ MRE 3} & $0^{A}$ & 22 & 28 & 86 & 102 \\
\hline & 15.6 & 40 & - & - & - \\
\hline & 31.25 & 41 & - & 111 & - \\
\hline & 62.5 & $19^{c}$ & 50 & 137 & 111 \\
\hline & 125 & $1^{\mathrm{C}}$ & $68^{*}$ & 125 & 157 \\
\hline & 250 & - & $63^{*}$ & $48^{\mathrm{C}}$ & 213 \\
\hline & 500 & - & $77^{*}$ & - & 194 \\
\hline \multirow[t]{2}{*}{$2 \mathrm{AA}$} & $0^{\mathrm{A}}$ & 22 & 28 & 86 & 102 \\
\hline & 2.5 & - & 1176 & - & 1787 \\
\hline \multirow[t]{2}{*}{ TNF } & $0^{A}$ & 22 & 28 & 86 & 102 \\
\hline & & 980 & - & - & - \\
\hline
\end{tabular}

${ }^{\text {A }}$ DMSO solvent control ${ }^{\mathrm{B}}$ Not tested ${ }^{\mathrm{C}}$ Too much cytotoxicity ${ }^{*}$ Positive response 


\title{
The Genotoxicity Studies of Mild Gasification Product, MRE\#1, in Mammalian Cells
}

\author{
INTRODUCTION .
}

The major hypothesis of carcinogenesis is that malignancy is due to an alteration (mutation) of the genetic material in a somatic cell. Reactive electrophilic metabolites are generated from many chemicals by the action of endogenous mixed function oxidases. These reactive metabolites may bind to cellular macromolecules such as DNA, and can, therefore, initiate a mutagenic or carcinogenic event. Prokaryotes and non-mammalian eukaryotes are used in mutation assays, while cultured mammalian cells are generally used for mutagenic as well as clastogenic tests examining alterations and damage to the DNA and/or chromosomes of somatic cells. One of the first mammalian cell lines used in genotoxicity studies is V79, which was derived from Chinese hamster lung cells.

According to the test plan on toxicity studies of mild gasification products, mammalian cell in vitro assays are to be performed on selected samples displaying mutagenic activity in the Ames assay. The results of the Ames testing of the mild gasification sample MRE\#1 indicate weak, but significant mutagenic activity. Hence, assays for the induction of gene mutation, sister chromatid exchange and micronucleus formation in V79 cells have been carried out for the sample. This paper reports the results of these assays.

\section{METHODS AND MATERIALS}

Sample description

MRE\#1, a product of the mild gasification of coal, is a complex mixture with a boiling point of $216^{\circ} \mathrm{F}$ with a tar odor and thick consistency. The sample was obtained from Maumee Research and Engineering, Inc. of Perrysburg, OH. The sample was produced by SGI's LFC mild gasification process from coal mined from the Rosebud Seam at Sarpy Creek, MT.

\section{Sample preparation}

MRE\#1 was melted by warming to $80^{\circ} \mathrm{C}$ in a water bath. $0.236 \mathrm{~g}$ of the sample was put into a sterile vial, and $11.6 \mathrm{ml}$ dimethyl sulfoxide (DMSO) was added. The combination was warmed to $50^{\circ} \mathrm{C}$ and sonicated in a Branson Model 3200 water bath/sonicator for 30 minutes and vortexed until a homogenous solution with a concentration of $20 \mathrm{mg} / \mathrm{ml}$ was achieved. The sample was further diluted with DMSO by one half dose in turn $(12.5,6.25$, $3.12,1.56 \mathrm{mg} / \mathrm{ml} \mathrm{etc.)}$.

DMSO was purchased from Fisher Scientific Company, Fair Lawn, NJ. $\mathrm{N}$-methyl-N'-nitro-N-nitrosoguanidine (MNNG), used as a postive control, was purchased from Aldrich Chemical Company, Inc., Milwaukee, WI. 


\section{Cell line and culture conditions}

The Chinese hamster lung fibroblast (V79) cell line was kindly supplied by C.C. Chang (Michigan State University). Cells were certified to be free of mycoplasma contamination by the standard MycoTect assay (Gibco, Gaithersburg, MD). Stock cultures were maintained in a monolayer in a $75 \mathrm{~cm}^{2}$ flask with growth medium - minimum essential medium (MEM, Gibco) supplemented with $10 \%$ heat-inactivated fetal bovine serum (FBS, Gibco), $100 \mathrm{u} / \mathrm{ml}$ penicillin and $100 \mu \mathrm{g} / \mathrm{ml}$ streptomycin (Gibco) - at $37^{\circ} \mathrm{C}$ and $100 \%$ humidity in $5 \% \mathrm{CO}_{2} / 95 \%$ air. The cells were passaged every $3-4$ days by treatment with a trypsin-EDTA solution (Gibco) in phosphate buffered saline (PBS) to prevent the cultures from becoming confluent. Working cultures of this cell line were maintained under the same conditions for the described assays.

\section{Assay procedures}

\section{HGPRT gene mutation assay}

Hypoxanthine-guanine-phosphoribosyl transferase (HGPRT) is an enzyme consisting of 2-4 protein subunits that catalyzes the salvage of hypoxanthine and guanine by the conversion of these purines to the corresponding nucleoside-5-monophosphates (necessary components of DNA, required for cell division and culture growth) upon reaction with phosphoribosyl pyrophosphate. The enzyme also catalyzes the conversion of the purine analogs (poisons) 6-mercaptopurine (MP), 6-thioguanine (TG), and 8-azaguanine (AG) into their lethal nucleoside-5-monophosphate forms. V79 cells with mutations that inactivate the product of the HGPRT gene locus, on the X chromosome in humans and rodents, will grow in medium containing the poisonous purine analogs that kill cells with normal HGPRT levels, because they can't metabolize exogenous purines or their deadly analogs. In order to survive, however, these mutants must rely on their ability to synthesize the required purines by a de novo pathway. Aminopterin is a substance that inhibits the de novo synthesis of nucleotides, making a cell dependent on exogenous hypoxanthine, glycine and thymidine. When cultured in medium containing hypoxanthine, aminopterin, thymidine and glycine (HAT medium), mutated V79 cells die because they cannot utilize the exogenous hypoxanthine or synthesize their own purines via the de novo pathway. V79 clones with a mutation inactivating the HGPRT gene product are selected by both 6-thioguanine resistance (TG) and inability to survive in HAT medium. Induction of the $\mathrm{TG}^{\mathrm{r}}$ mutation will be carried out according to the protocol recommended by E.R. Nestman (1991), based on a survey of current practice in genotoxicity testing laboratories.

Six chemical concentrations, a negative control, and a positive control were tested with and without S9 metabolic activation. $5 \times 10^{5}$ cells were seeded in $25 \mathrm{~cm}^{2}$ flasks containing $5 \mathrm{ml}$ growth medium and incubated at $37^{\circ} \mathrm{C}$ in a humid atmosphere of $5 \% \mathrm{CO}_{2}$. Twenty-four hours later, the medium was replaced with treatment medium containing $4.5 \mathrm{ml}$ serum-free medium and $0.5 \mathrm{ml} \mathrm{S} 9$ mixture (for metabolic activation), or $5 \mathrm{ml}$ serum-free medium without S9 (for testing direct-acting mutagens), and $50 \mu 1$ MRE\#1 sample. After a 3-hour exposure, the cells were rinsed twice with PBS and trypsinized, then replated in two $100 \mathrm{~mm}$ dishes at $2.5 \times 10^{5}$ for the mutation studies and in six $60 \mathrm{~mm}$ dishes at 100 cells/dish for 
measurement of cell survival. Following a 7-day incubation period, the cultures in the 60 $\mathrm{mm}$ dishes were fixed, stained and counted. Cell survival relative to the untreated controls (i.e., the relative colony forming efficiency; $C F E$ ) was determined for each dose level tested; relative $\mathrm{CFE}=$ (the number of colonies with treatment/ the number of colonies in the control) $\times 100 \%$. At least four treatment concentrations should be included which give relative CFEs ranging between 10 and $100 \%$.

The cultures in the $100 \mathrm{~mm}$ dishes, prepared for the mutation studies, were also incubated at $37^{\circ} \mathrm{C}$ for the expression period of 7 days; during which time, the cells were passaged two or three times. After a week, the cells were washed with PBS and trypsinized in preparation for plating another CFE and expression assay. 100 cells/dish were seeded in $60 \mathrm{~mm}$ dishes containing $5 \mathrm{ml}$ MEM. Six dishes per treatment were used. These cultures were fixed and stained with Giemsa after 7 days to determine the relative CFE. Approximately $2.5 \times 10^{5}$ cells were seeded in $100 \mathrm{~mm}$ dishes (six per treatment) containing $10 \mathrm{ml}$ of selection medium (94\% hypoxanthine-free MEM, 5\% dialyzed FBS, $1 \% 1 \mathrm{mM}$ 6-thioguanine solution). The selection plates were incubated for 10 days; after which the colonies were fixed, stained and counted by eye. The criterion for minimum acceptable colony size was a diameter of $0.5 \mathrm{~mm}$ or greater or a minimum of 50 cells per colony. Mutation frequency $(\mathrm{MF})=$ number of mutant colonies/(total cells seeded on all replicate plates $\mathrm{x}$ absolute CFE). Solvent and MNNG were tested simultaneously as solvent and positive controls, respectively.

\section{Sister Chromatid Exchange (SCE) Assay}

The in vitro SCE assay is frequently used for evaluating the potential of chemicals to induce genetic damage. Although the molecular basis of SCE formation remains unknown, SCEs represent the breakage of 4 stands of DNA ( 2 double helices), a switch of those strands between chromatids of the same chromosome, and the rejoining of those strands in their new location. It is important to know whether the breakage and rejoining events occur faithfully (i.e. without producing any modification in the genetic code). Several studies have demonstrated that the frequency of SCE increases when cells are exposed to known mutagens and carcinogens.

The method followed has been detailed by L. Soler-Niedzieda (1989). Approximately 6 X $10^{5}$ V79 cells were seeded into $100 \mathrm{~mm}$ dishes, containing $10 \mathrm{ml}$ growth medium and incubated at $37^{\circ} \mathrm{C}$. Twenty-four hours later, the medium was removed and replaced with treatment medium containing $9 \mathrm{ml}$ serum-free medium and $1 \mathrm{ml} \mathrm{S} 9$ mixture, or $10 \mathrm{ml}$ serum-free medium without S9 treatment. The 4-6 concentrations of MRE\#1 used were determined by the survival test included in the gene mutation assay. After a 3-hour treatment, the cells were washed with PBS, trypsinized, and reseeded into two dishes per treatment with $10 \mathrm{ml}$ fresh medium. One dish was used for micronucleus induction; the other for the SCE assay. Solvent and positive (MNNG) controls were run concurrently with each experiment.

For the SCE assay, 5-bromo-2'-deoxyuridine (BrdU, Sigma) was added to each dish to a final concentration of $20 \mu \mathrm{M}$, followed by a $28-30$-hour incubation in the dark. Two hours 
before harvesting, colcemid was added at a final concentration of $1 \mu \mathrm{M}$. The cells were harvested by trypsinization, washed by centrifugation, resuspended in $75 \mu \mathrm{M} \mathrm{KCl}$ hypotonic solution for $20 \mathrm{~min}$ at $37^{\circ} \mathrm{C}$, and fixed 3 times in a 3:1 mixture of methanol-acetic acid. Two drops of the cell suspension was dropped onto a cold, wet slide which was then waved through a spirit flame. After aging overnight, the slides were stained using the fluorescenceGiemsa method (Soler-Niedzieda, 1989). One hundred metaphases from each treatment were counted for replicative index determination, while 30 cells having 20-23 welldistinguished and well-spread chromosomes were scored for SCEs. The results are expressed as the mean number of SCEs per metaphase \pm S.D. The grouped $t$ test was used to compare the average frequencies of SCEs induced by MRE\#1.

\section{Micronucleus (MN) assay}

Micronuclei are small chromatin-containing bodies arising from acentric chromosomal fragments or whole chromosomes that were not incorporated into the daughter nuclei following mitosis. The presence of $\mathrm{MN}$ can be taken as an indication of chromosome breakage and/or spindle dysfunction (Gu, 1992). Treatment of V79 cells with MRE\#1 and preparation of the cell suspension after exposure is described in the procedures for the SCE assay. After treatment, cells were incubated for $24 \mathrm{hrs,} \mathrm{harvested} \mathrm{by} \mathrm{trypsinization,} \mathrm{washed}$ by centrifugation, and resuspended in growth medium to an optimum density. Slides were prepared using cytocentrifugation. An aliquot of cell suspension (50-75 $\mu \mathrm{l})$ was loaded into a chamber, and the cells were pelleted onto slides at $600 \mathrm{rpm}$ for $7 \mathrm{~min}$, then stained with Diff-Quik stain (Dage Diagnostics, Aquada, PR). The frequency of micronucleated cells in each treatment is based on 3000 cells scored. The criteria used to scored MN were the following: (1) the diameter of micronucleus must be no larger than one-fifth of the main nucleus; (2) the staining intensity must be equal to that of nucleus; (3) the micronucleus must be located in cytoplasm; and (4) there must be no contact with the main nucleus. The results are expressed as an average number of cells with $\mathrm{MN}$ per 1000 cells \pm S.D. Statistical analysis is based on the trend test and the Chi-square test.

\section{RESULTS AND DISCUSSION}

Results of the cytotoxicity testing of MRE\#1 indicate that the test chemical significantly reduced the survival of cultured V79 cells at the concentration range of $15.6-62.5 \mu \mathrm{g} / \mathrm{ml}$ without S9 activation (Table 1). There was less killing effect induced by the test sample under the conditions tested in the presence of S9. This may be due to an inactivation of the cytotoxicity by the metabolic enzymes in the S9.

Results of the HGPRT gene mutation assay are shown in Table 2. V79 cells were exposed to MRE\#1 at doses as high as $62.5 \mu \mathrm{g} / \mathrm{ml}$, both with and without $\mathrm{S} 9$ activation; however, none of the concentrations tested significantly increased the frequency of $T^{r}$ mutants. No dose response or minimum of a three-fold increase over the spontaneous level was noted. Therefore, no evidence of induction of gene mutations was noted under the conditions tested. The study was repeated, and the results confirmed. 
The frequencies of $\mathrm{MN}$ and SCE induced by MRE\#1 at various concentrations are presented in Tables 3 and 4, respectively. An increase in the frequency of MN formation was seen when cells were treated with MRE\#1 at concentrations ranging from 7.8 to $31.2 \mu \mathrm{g} / \mathrm{ml}$ without S9 metabolic activation, and at concentrations of 15.6 and $62.5 \mu \mathrm{g} / \mathrm{ml}$ with S9. MRE\#1 induced a significant increase in the SCE frequency throughout the dose range tested $(2.0-31.2 \mu \mathrm{g} / \mathrm{ml} ; \mathrm{p}<0.01)$, with and without metabolic activation. The observed increases in both MN and SCE are dose-dependent and statistically significant.

These results indicate that MRE\# 1 can cause DNA damage, chromosome breakage and/or spindle fiber dysfunction in V79 cells without metabolic activation by S9. Therefore, it appears that direct-acting genotoxic agents are present in the sample MRE\#1. Like its cytotoxic effect, the genotoxic potential of this agent appears to be detoxified to some extent by metabolic activation with a rat liver preparation.

\section{REFERENCES}

Gu, Zu-wei, B.Z. Zhong et al. (1992) Micronucleus induction and phagocytosis in mammalian cells treated with diesel emission particles, Mutation Research, 279;5560.

Nestman, E.R., R.L. Brillinger, J.P.W. Gilman, C.J. Rudd and S.H.H. Swierenga (1991) Recommended protocols based on a survey of current practice in genotoxicity testing laboratories: Mutation in Chinese hamster ovary, V79 Chinese hamster lung and L5178Y mouse lymphoma cells, Mutation Research, 246;255-284.

Soler-Niedzieda, L., T.M. Ong et al. (1989) Sister chromatid exchange studies on direct- and indirect-acting clastogens in mouse primary cell cultures, Mutation Research 224;465470. 
Table 1. Cytotoxicity of MRE\#1 to V79 Cells

\begin{tabular}{|c|c|c|c|c|c|}
\hline \multirow{3}{*}{$\begin{array}{l}\text { Chemical } \\
\text { treatment }^{\mathrm{a}}\end{array}$} & \multirow{3}{*}{$\begin{array}{l}\text { Concentration } \\
(\mu \mathrm{g} / \mathrm{ml})\end{array}$} & \multicolumn{4}{|c|}{ Relative colony forming efficiency ${ }^{b}$} \\
\hline & & \multicolumn{2}{|c|}{$-\mathrm{S} 9$} & \multicolumn{2}{|c|}{$+\mathrm{S} 9$} \\
\hline & & Mean \pm SD & $\%$ & Mean \pm SD & $\%$ \\
\hline \multirow{6}{*}{ MRE\#1 } & $0.0^{\mathrm{c}}$ & $68 \pm 6$ & 100 & $59 \pm 11$ & 100 \\
\hline & 3.9 & $52 \pm 8$ & 76 & $48 \pm 8$ & 81 \\
\hline & 7.8 & $44 \pm 5$ & 65 & $34 \pm 6$ & 58 \\
\hline & 15.6 & $32 \pm 3$ & 47 & $40 \pm 5$ & 68 \\
\hline & 31.2 & $18 \pm 5$ & 26 & $69 \pm 8$ & 117 \\
\hline & 62.5 & $20 \pm 6$ & 29 & $25 \pm 3$ & 42 \\
\hline $\mathrm{MNNG}^{\mathrm{d}}$ & 1.0 & $36 \pm 6$ & 53 & $48 \pm 11$ & 81 \\
\hline
\end{tabular}

3 h exposure

${ }^{b}$ Relative $\mathrm{CFE}=\frac{\text { Absolute CFE (treatment) }}{\text { Absolute CFE (control) }} \times 100$
' DMSO solvent control

${ }^{d} \mathrm{~N}$-methyl-N'-nitro-N-nitrosoguanidine

Table 2. Frequency of 6-thioguanine Resistant Mutants in V79 Cells Treated with MRE\#1

\begin{tabular}{|c|c|c|c|c|c|}
\hline \multirow[t]{2}{*}{$\begin{array}{l}\text { Chemical } \\
\text { treatment }^{\mathrm{a}}\end{array}$} & \multirow[t]{2}{*}{$\begin{array}{c}\text { Concentration } \\
(\mu \mathrm{g} / \mathrm{ml})\end{array}$} & \multicolumn{2}{|c|}{$\begin{array}{l}\text { Relative Survival } \\
(\%)\end{array}$} & \multicolumn{2}{|c|}{$\begin{array}{c}\text { Mutants per } 10^{5} \\
\text { Survivors (Mean } \pm \text { SD) }\end{array}$} \\
\hline & & $-\mathrm{S} 9$ & $+S 9$ & $-\mathrm{S} 9$ & $+\mathrm{S} 9$ \\
\hline \multirow[t]{6}{*}{ MRE\#1 } & $0.0^{\mathrm{b}}$ & 100 & 100 & $2.3 \pm 0.8$ & $2.4 \pm 1.3$ \\
\hline & 3.9 & 76 & 81 & $1.9 \pm 1.0$ & $1.8 \pm 0.9$ \\
\hline & 7.8 & 65 & 58 & $2.2 \pm 1.2$ & $2.1 \pm 0.8$ \\
\hline & 15.6 & 47 & 68 & $0.9 \pm 0.5$ & $0.6 \pm 0.5$ \\
\hline & 31.2 & 26 & 117 & $1.3 \pm 0.9$ & $0.8 \pm 0.5$ \\
\hline & 62.5 & 29 & 42 & $1.4 \pm 1.3$ & $0.5 \pm 0.5$ \\
\hline $\mathrm{MNNG}^{\mathrm{c}}$ & 1.0 & 53 & 81 & $40.9 \pm 8.4$ & $6.2 \pm 2.8$ \\
\hline
\end{tabular}


Table 3. Frequency of Micronuclei in V79 cells Treated with MRE\#1

\begin{tabular}{|c|c|c|c|c|c|}
\hline \multirow[t]{2}{*}{$\begin{array}{l}\text { Chemical } \\
\text { treatment }\end{array}$} & \multirow[t]{2}{*}{$\begin{array}{l}\text { Concentration } \\
(\mu \mathrm{g} / \mathrm{ml})\end{array}$} & \multicolumn{2}{|c|}{$\begin{array}{c}\text { Total Number of } \\
\text { MN Cells }{ }^{\mathrm{b}} \\
\end{array}$} & \multicolumn{2}{|c|}{$\begin{array}{c}\text { Frequency of MN Cells \%o } \\
(\text { Mean } \pm \text { SD) }\end{array}$} \\
\hline & & $-\mathrm{S} 9$ & $+\mathrm{S} 9$ & $-\mathrm{S} 9$ & $+\mathrm{S} 9$ \\
\hline \multirow[t]{7}{*}{ MRE\#1 } & $0.0^{c}$ & 13 & 18 & $4.3 \pm 0.6$ & $6.0 \pm 1.7$ \\
\hline & 2.0 & 31 & 26 & $10.3 \pm 1.5^{* *}$ & $8.7 \pm 0.6$ \\
\hline & 3.9 & 20 & 17 & $6.7 \pm 0.6$ & $5.7 \pm 2.3$ \\
\hline & 7.8 & 33 & 10 & $11.0 \pm 2.7^{* *}$ & $3.3 \pm 0.6$ \\
\hline & 15.6 & 53 & 49 & $17.7 \pm 2.1^{* *}$ & $16.3 \pm 1.2^{* *}$ \\
\hline & 31.2 & 87 & 30 & $29.0 \pm 2.7^{* *}$ & $10.0 \pm 2.0$ \\
\hline & 62.5 & $-d$ & 60 & $\mathrm{~d}^{-}$ & $20.0 \pm 6.0^{* *}$ \\
\hline $\mathrm{MNNG}^{\mathrm{e}}$ & 2.0 & 159 & 88 & $53.0 \pm 7.8^{* *}$ & $29.3 \pm 2.9^{* *}$ \\
\hline
\end{tabular}

3 h exposure

b 3000 cells were scored

c DMSO solvent control

d cytotoxic

e $\mathrm{N}$-methyl-N'-nitro-N-nitrosoguanidine
- $p<0.05$, trend test and Chi-square test

${ }^{* *} p<0.01$, trend test and Chi-square test

Table 4. Frequency of Sister Chromatid Exchange in V79 Cells Treated with MRE\#1

\begin{tabular}{|c|c|c|c|c|c|}
\hline \multirow[t]{2}{*}{$\begin{array}{l}\text { Chemical } \\
\text { treatment }^{\mathrm{a}}\end{array}$} & \multirow[t]{2}{*}{$\begin{array}{l}\text { Concentration } \\
(\mu \mathrm{g} / \mathrm{ml})\end{array}$} & \multicolumn{2}{|c|}{$\begin{array}{c}\text { SCE / Cell } \\
(\text { Mean } \pm \text { SD) }\end{array}$} & \multicolumn{2}{|c|}{$\begin{array}{l}\text { Replication } \\
\text { Index }\end{array}$} \\
\hline & & $-\mathrm{S} 9$ & $+S 9$ & $-\mathrm{S} 9$ & $+\mathrm{S} 9$ \\
\hline \multirow[t]{6}{*}{ MRE\#1 } & $0.0^{c}$ & $5.7 \pm 1.2$ & $5.8 \pm 1.3$ & 2.1 & 2.0 \\
\hline & 2.0 & $7.9 \pm 2.1^{* *}$ & $7.6 \pm 2.1^{* *}$ & 2.2 & 2.2 \\
\hline & 3.9 & $8.1 \pm 2.3^{* *}$ & $7.0 \pm 2.8^{* *}$ & 2.2 & 2.1 \\
\hline & 7.8 & $8.1 \pm 3.1^{* *}$ & $7.0 \pm 1.8^{* *}$ & 2.1 & 2.2 \\
\hline & 15.6 & $10.3 \pm 3.9^{* *}$ & $9.1 \pm 2.3^{* *}$ & 2.2 & 2.1 \\
\hline & 31.2 & $7.8 \pm 1.8^{* *}$ & $7.3 \pm 1.6^{* *}$ & 2.0 & 2.0 \\
\hline $\mathrm{MNNG}^{\mathrm{d}}$ & 1.0 & $24.9 \pm 6.9^{* *}$ & $18.1 \pm 5.1^{* *}$ & 1.9 & 2.0 \\
\hline $\begin{array}{l}\text { a } 3 \text { h exposure } \\
\text { b } 30 \text { metaphase cel } \\
\text { c DMSO solvent cc }\end{array}$ & $\begin{array}{l}\text { were scored } \\
\text { trol }\end{array}$ & 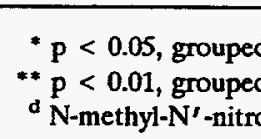 & itrosoguanidine & & \\
\hline
\end{tabular}




\section{APPENDIX C}

SAMPLE PRODUCTION REPORT FOR USIBELLI (ALASKAN) COAL

FOR "PRODUCTION OF MILD GASIFICATION CO-PRODUCTS" PROJECT

Topical Report (FINAL)

By:

D. A. Horne

J. C. Castro

December 4, 1994

Work Performed Under Contract NO.: DE-AC21-91MC27240

For:

U.S. Department of Energy

Morgantown Energy Technology Center

Morgantown, West Virginia

By:

SGI Fuels, Incorporated

La Jolla, California 


\section{EXECUTIVE SUMMARY}

Three (3) 55 gallon barrels from each of two seams of Usibelli subbituminous coal (seams 3 and 4) were sampled from the Usibelli Mine located near Healy, Alaska, on 15 December 1992. Healy is near the eastern border of the Delani National Park. These samples were crushed and sized to $-5 / 8^{\prime \prime}+$ 1/4" for processing to produce Liquids From Coal (LFC) liquid and solid co-products. A total of 352 lbs. of raw coal was processed through SGI's sample production unit (SPU) producing $169 \mathrm{lbs}$ of simulated process derived fuel (PDF) and $26.2 \mathrm{lbs}$. of coal derived liquid (CDL) co-products. Testing results show that the processing upgraded the coal by removing the water from the coal (25\% by weight), increasing its heating value from 8,284 to $11,577 \mathrm{BTU} / \mathrm{lb}$. The sulfur analysis for this coal and its resulting PDF shows a net increase in the pounds of $\mathrm{SO}_{2}$ per million BTU $(0.36$ and 0.47 lbs. $\mathrm{SO}_{2} / \mathrm{MMBTU}$ for the feed coal and PDF respectively). A check of the sulfur balance shows good agreement. There was $0.50 \mathrm{lbs}$. of sulfur fed with the dry coal, resulting in $0.46 \mathrm{lbs}$. of sulfur in the PDF and $0.02 \mathrm{lbs}$. sulfur in the CDL, leaving $0.02 \mathrm{lbs}$. of sulfur in the gas. However, the sulfur content in both the coal and PDF is still well below clean air act limits.

The CDL has properties similar to tar sand oil with a pour point in the $95^{\circ}$ to $110^{\circ} \mathrm{F}$ range. The specific gravity of the oil is near 1.02 giving an API gravity of $6.6^{\circ}$. Most of the hydrogen compounds in the $\mathrm{CDL}$ are involved in paraffinic structures $\left(-\mathrm{CH}_{2}-\right)$. The $\mathrm{CDL}$ has a molar $\mathrm{H} / \mathrm{C}$ ratio of 1.36. This compares to 2.2 for simple paraffins, and 0.8 for naphthalene.

The CDL is only weakly mutagenic as determined by NIOSH. 
TABLE OF CONTENTS

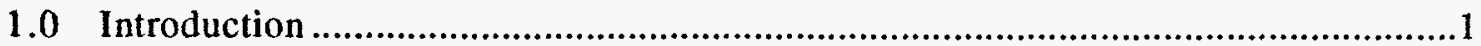

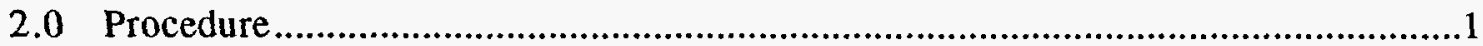

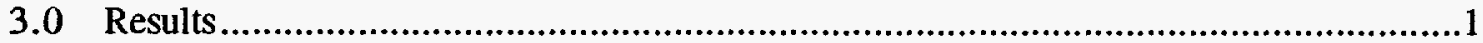

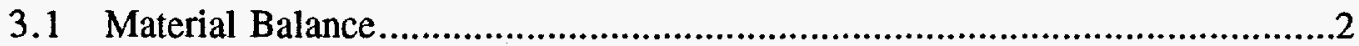

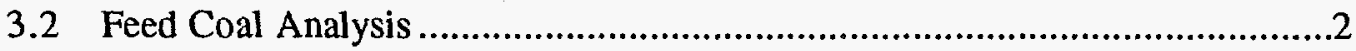

3.2.1 SGI Development Center ..............................................................2

3.2.2 Commercial Testing and Engineering Analysis..............................

3.3 Simulated PDF Analysis..........................................................................

3.3.1 SGI Development Center .............................................................

3.3.2 Commercial Testing and Engineering Analysis..............................4

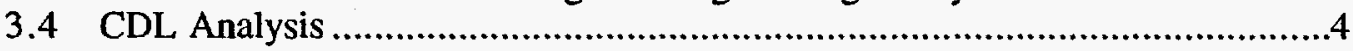

3.4.1 SGI's Development Center, NMR Analysis ...................................

3.4.2 Commercial Testing and Engineering ........................................

3.4.3 National Institute of Occupational Safety and Health (NIOSH) ......7

4.0 Conclusions

Appendix I Commercial Testing and Engineering Analysis Sheets....................................10

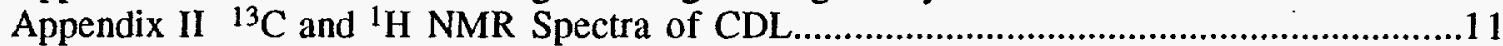

Appendix III National Institute for Occupational Safety and Health Data Sheets................12 


\section{TABLES}

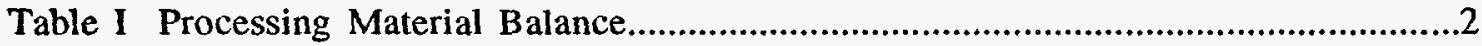

Table II SGI ASTM Proximate Analysis of Raw Coal.......................................................2

Table III CTE Raw Coal Proximate and Ultimate Analysis Results.....................................

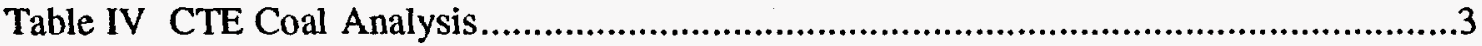

Table V SGI ASTM Proximate Analysis of Simulated PDF.............................................4

Table VI CTE Simulated PDF Proximate and Ultimate Analysis Results.........................5

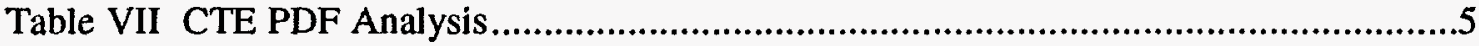

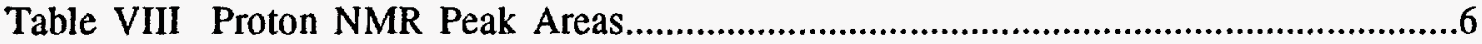

Table IX Commercial Testing and Engineering Blended CDL Analysis ...........................7

Table X Usibelli CDL Distillation Analysis..................................................................8

\section{FIGURES}

Figure 1 CDL Distillation Curve. 


\subsection{Introduction}

The Liquids From Coal (LFC) Process, developed by SGI International, employs a mild gasification procedure to produce two co-products, a Coal Derived Liquid (CDL) and a solid Process Derived Fuel (PDF). The CDL is formed from the condensation of volatile matter removed from the coal during the LFC Process, and the PDF is the remaining solid product after most of the moisture and some of the volatile matter have been removed. In an effort to examine and classify these two mild gasification co-products, SGI Fuels, Inc. entered into an agreement with the Morgantown Energy Technology Center (METC) to produce liquid and solid co-product samples using the LFC Process on four (4) coals from three major coal resource regions in the United States. Those regions were designated to be the Powder River Basin, the Williston Basin, and Alaska. The purpose of this report is to describe the procedure of processing Usibelli coal (Alaskan coal) to produce solid and liquid coproducts and to identify the characteristics of the co-products. Usibelli coal was obtained from the Usibelli Mine located on the eastern edge of the Delani National Park, near the town of Healy in the state of Alaska. The Usibelli Mine produces subbituminous coal from several seams; the majority of the mine's output comes from seams 3 and 4, and these seams were sampled for this study.

\subsection{Procedure}

Samples of coal were taken from freshly mined faces of two different seams. Sampling started at about 10:00 AM on 15 December 1992. At the time of sampling, the sky was clear, and the temperature was crisp at about $15^{\circ} \mathrm{F}$. The samples were packaged in 55 gallon polyethylene drums with sealing lids for shipment to the SGI Development Center. After receipt of the samples at the Development Center, the coal was prepared for processing by crushing and sizing to $-5 / 8+1 / 4$ inch. Coal samples were prepared and packaged in sealed 5 gallon plastic pails for later shipment to laboratories for analysis and testing.

The sized coal was dried in the Sample Production Unit (SPU) and then allowed to cool in sealed stainless steel containers. Once the dried coal was cool, it was stored under nitrogen in sealed 5 gallon plastic pails for later pyrolysis in the SPU.

The dried coal was pyrolyzed in the SPU and then allowed to cool in sealed stainless steel containers in the same manner as the dry coal. After the coal had cooled to about room temperature, it was spread in a thin layer on a plastic sheet to partially oxidize the char. Water was then sprayed in a fine mist to partially rehydrate the char to produce simulated PDF. The water was preweighed so that $5 \%$ moisture would be added to the char.

During the pyrolysis runs, the CDL was collected in an electrostatic precipitator (ESP) operating at 30,000 volts in a constant current mode. To condense oil and not water, the ESP was maintained at $130^{\circ} \mathrm{F}$, above the dew point of water. The CDL was removed from the ESP by gravity and stored in sealed one liter borosilicate glass bottles.

During these standard sequences, no attempt was made to optimize the mild pyrolysis process with the heat rate, peak temperatures, or heating duration. The LFC Process, the SPU, and the ENCOAL Demonstration plant at Gillette, WY, are sufficiently flexible to produce co-products with a wide range of characteristics to meet the end users requirements.

\subsection{Results}

The coal was crushed and sized on 18 and 19 February 1993. Processing started on 23 February 1993, and sized coal was dried over a period of five (5). After drying, the coal was pyrolyzed starting on 16 March 1993, and the process continued for four (4) days. No difficulties with bed pressures or equipment plugging were encountered during the procedure. The aspect ratio of this coal was similar to Buckskin and was not very friable as indicated by the small amount of fines produced (less than 
one pound).

\subsection{Material Balance.}

During these runs, a total of 352 pounds of raw coal was processed yielding 250 pounds of dry coal. The dry coal was pyrolyzed to yield 169 pounds of char and 26.2 pounds of CDL. Table I summarizes the material balance.

Table I Processing Material Balance

\begin{tabular}{|l|r|}
\hline \multicolumn{1}{|c|}{ Material } & \multicolumn{1}{c|}{ Total } \\
\hline Raw Coal, lbs. & 352 \\
\hline Dry Coal, lbs. & 250 \\
\hline Fines, lbs. & 0.8 \\
\hline Moisture (by difference), lbs & 101.2 \\
\hline Dry Feed, lbs. & 250 \\
\hline Char, lbs. & 169.2 \\
\hline CDL, lbs. & 26.2 \\
\hline $\begin{array}{l}\text { Gas and Light hydrocarbons } \\
\text { (by difference), lbs }\end{array}$ & 54.6 \\
\hline
\end{tabular}

\subsection{Feed Coal Analysis}

A Proximate analysis of the feed coal was conducted at the Development Center. Samples of feed coal also were sent to Commercial Testing and Engineering, Inc., for analysis.

\subsubsection{SGI Development Center}

Table II summarizes the results of the Development Center's Proximate analysis and heat of combustion determination for the feed coal.

Table II SGI ASTM Proximate Analysis of Raw Coal

\begin{tabular}{||r|r|r|}
\hline & Raw Coal & Bone Dry Basis \\
\hline Moisture & 23.53 & -- \\
\hline Volatiles & 36.10 & 47.21 \\
\hline Fixed Carbon & 34.18 & 44.70 \\
\hline Ash & 6.19 & 8.09 \\
\hline BTU/lb & 8,023 & 10,492 \\
\hline
\end{tabular}




\subsubsection{Commercial Testing and Engineering Analysis.}

A sample of sized raw coal was sent to Commercial Testing and Engineering, Inc. in South Holland, IL, for Proximate analysis, Ultimate analysis, and associated tests to determine forms of sulfur, grindability, percent equilibrium moisture, and apparent specific gravity. Table III summarizes the results for the Proximate and Ultimate analysis including the heat of combustion. Data sheets for this analysis may be found in Appendix I.

Table III CTE Raw Coal Proximate and Ultimate Analysis Results

\begin{tabular}{||l|l|r|r||}
\hline \multicolumn{1}{|c|}{ Method } & \multicolumn{1}{|c|}{ Sample } & Raw Coal & Bone Dry Basis \\
\hline D 3302 & \% Moisture & 25.15 & -- \\
\hline D 3175 & \% Volatiles & 32.55 & 43.49 \\
\hline D 3172 & \% Fixed Carbon & 36.94 & 49.35 \\
\hline D 3174 & \% Ash & 5.36 & 7.16 \\
\hline Infrared & \% Carbon & 48.54 & 64.85 \\
\hline Infrared & \% Hydrogen & 3.79 & 5.07 \\
\hline TC & \% Nitrogen & 0.72 & 0.96 \\
\hline D 4239 & \% Sulfur & 0.15 & 0.20 \\
\hline D 2015 & Heat of Combustion, BTU/1b & 8,284 & 11,067 \\
\hline
\end{tabular}

Other coal properties such as forms of sulfur, grindability, equilibrium moisture, and apparent specific gravity, as determined by CTE, are summarized in Table IV.

Table IV CTE Coal Analysis

\begin{tabular}{||l|l|c|c||}
\hline \multicolumn{1}{|c|}{ Method } & \multicolumn{1}{|c|}{ Analysis } & \multicolumn{2}{c|}{ Raw Coal } \\
\hline D 2492 & Forms of Sulfur & A.R. & B.D. \\
\hline & \% Pyritic & 0.01 & 0.01 \\
\hline & \% Sulfate & 0.01 & 0.01 \\
\hline & \% Organic (diff) & 0.13 & 0.18 \\
\hline D 409 & \multicolumn{1}{|c|}{ Total } & 0.15 & 0.20 \\
\hline D 3180 & Grindability & \multicolumn{2}{|c|}{33} \\
\hline USX Method & \% Equilibrium $\mathrm{H}_{2} \mathrm{O}$ & \multicolumn{2}{|c|}{23.0} \\
\hline & USX Oxidation Index & \multicolumn{2}{|c|}{1.23} \\
\hline
\end{tabular}


Based on CTE's analysis, the sulfur dioxide emission for the raw coal is $0.36 \mathrm{lbs}$ $\mathrm{SO}_{2} / \mathrm{MMBTU}$.

\subsection{Simulated PDF Analysis}

A Proximate analysis of the simulated PDF was conducted at the Development Center. Samples of the PDF also were sent to Commercial Testing and Engineering, Inc. for analysis.

\subsubsection{SGI Development Center}

Table V summarizes the results of the Development Center's Proximate analysis and heat of combustion determination for the PDF.

Table V SGI ASTM Proximate Analysis of Simulated PDF

\begin{tabular}{||r|r|r|}
\hline & Simulated PDF & Bone Dry Basis \\
\hline Moisture & 3.41 & -- \\
\hline Volatiles & 23.80 & 24.64 \\
\hline Fixed Carbon & 59.23 & 61.32 \\
\hline Ash & 13.56 & 14.04 \\
\hline BTU/hb & 11,343 & 11,743 \\
\hline
\end{tabular}

\subsubsection{Commercial Testing and Engineering Analysis.}

A sample of simulated PDF was sent to Commercial Testing and Engineering, Inc. in South Holland, IL, for Proximate analysis, Ultimate analysis, and associated tests to determine forms of sulfur, grindability, percent equilibrium moisture, and apparent specific gravity. Table VI summarizes the results for the Proximate and Ultimate analysis including the heat of combustion. Data sheets for this analysis may be found in Appendix $\mathbf{I}$.

Other coal properties such as forms of sulfur, grindability, equilibrium moisture, and apparent specific gravity, as determined by CTE, are summarized in Table VII.

Based on CTE's analysis, the sulfur dioxide emission for the simulated PDF is $0.47 \mathrm{lbs}$ $\mathrm{SO}_{2}$ /MMBTU.

\subsection{Analysis}

The Development Center obtained ${ }^{1} \mathrm{H}$ and ${ }^{13} \mathrm{C}$ NMR spectra of the CDL. Samples of CDL also were sent to Commercial Testing and Engineering, Inc., and the National Institutes for Occupational Safety and Health for analysis. 
Table VI CTE Simulated PDF Proximate and Ultimate Analysis Results

\begin{tabular}{||l|l|r|r|}
\hline \multicolumn{1}{|c|}{ Method } & \multicolumn{1}{|c|}{ Sample } & Simulated PDF & Bone Dry Basis \\
\hline D 3302 & \% Moisture & 3.06 & -- \\
\hline D 3175 & \% Volatiles & 27.54 & 28.41 \\
\hline D 3172 & \% Fixed Carbon & 59.01 & 60.87 \\
\hline D 3174 & \% Ash & 10.39 & 10.72 \\
\hline Infrared & \% Carbon & 69.76 & 71.96 \\
\hline Infrared & \% Hydrogen & 3.50 & 3.61 \\
\hline TC & \% Nitrogen & 1.13 & 1.17 \\
\hline D 4239 & \% Sulfur & 0.27 & 0.28 \\
\hline D 2015 & Heat of Combustion, BTU/lb & 11,577 & 11,942 \\
\hline
\end{tabular}

Table VII CTE PDF Analysis

\begin{tabular}{|l|l|c|c|}
\hline \multicolumn{1}{|c|}{ Method } & \multicolumn{1}{|c|}{ Analysis } & \multicolumn{2}{c|}{ PDF } \\
\hline D 2492 & Forms of Sulfur & A.R. & B.D. \\
\hline & \% Pyritic & 0.10 & 0.10 \\
\hline & \% Sulfate & 0.01 & 0.01 \\
\hline & \% Organic (diff) & 0.16 & 0.17 \\
\hline D 409 & Total & 0.27 & 0.28 \\
\hline D 3180 & Grindability & \multicolumn{2}{|c|}{59} \\
\hline USX Method & \% Equilibrium $\mathrm{H}_{2} \mathrm{O}$ & \multicolumn{2}{|c|}{10.4} \\
\hline & USX Oxidation Index & \multicolumn{2}{|c|}{82} \\
\hline
\end{tabular}

\subsubsection{SGI's Development Center, NMR Analysis}

NMR spectra are generally displayed on a chemical shift basis designated $\delta$ with units of ppm. Chemical shift is defined as:

$$
\delta_{i}=\frac{v_{i}-v_{T M S}}{v_{0}} \times 10^{6}
$$

where $v_{i}$ is the resonate frequency of nucleus $i, v_{0}$ is the operating frequency of the instrument, and $v_{\text {TMS }}$ is the resonate frequency of the protons (or ${ }^{13} \mathrm{C}$ nuclei) in the internal standard, tetramethylsilane. For the proton spectra, the operating frequency 
of the instrument $\left(v_{0}\right)$ is $400 \mathrm{MHz}$, and for the ${ }^{13} \mathrm{C}$ spectra, $v_{0}=101 \mathrm{MHz}$.

Reproductions of the ${ }^{1} \mathrm{H}$ and ${ }^{13} \mathrm{C}$ spectra may be found in the Appendix II.

\section{Proton $\left({ }^{1} \mathrm{H}\right)$ Spectra}

The proton NMR spectra may be divided into two general areas. At low chemical shift $(\delta=0$ to $3 \mathrm{ppm})$, one finds peaks associated with protons attached to saturated carbons, and at higher chemical shift $(\delta=6$ to $8 \mathrm{ppm})$, one finds peaks associated with protons attached to aromatic carbons. The area between the saturated (or aliphatic) and the aromatic regions is occupied by peaks for protons bound to isolated carbon-carbon double bonds and protons bound directly to hetero atoms such as oxygen and nitrogen.

The major peak observed in the CDL proton spectra is a sharp signal centered at 1.25 ppm. This signal corresponds to protons bound to carbons in straight chain hydrocarbons $\left(-\mathrm{CH}_{2}-\right)$.

The CDL also shows a signal centered at $3.7 \mathrm{ppm}$. This peak is in the general region of the proton NMR spectra where hetero atom bound methyl or methylene functions are found (i.e., $-\mathrm{O}-\mathrm{CH}_{3}$ or $-\mathrm{O}-\mathrm{CH}_{2}-$ ).

The ratios of "saturated" protons (protons bound to saturated carbon atoms) to "aromatic" protons (protons bound to aromatic carbon atoms) may be determined by integrating the area under the peaks in the appropriate regions. Table VIII summarizes these areas and the ratio of saturated to aromatic protons for Usibelli CDL.

Table VIII Proton NMR Peak Areas

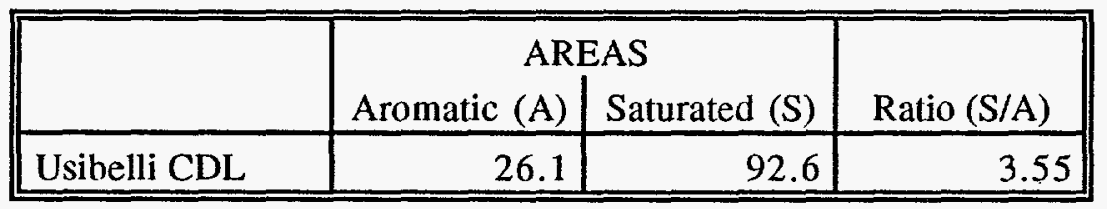

\section{Carbon $\left({ }^{13} \mathrm{C}\right)$ Spectra}

All of the ${ }^{13} \mathrm{C}$ spectra are proton noise decoupled. This reduces the complexity of the spectra (each carbon shows up as a singlet) and enhances the signal to noise ratio. This enhancement is important because the procedure relies on the natural abundance of ${ }^{13} \mathrm{C}$ for the NMR measurement $\left({ }^{12} \mathrm{C}\right.$ is not sensitive to the NMR experiment). The natural abundance of ${ }^{13} \mathrm{C}$ is $1.1 \%$ and its relative sensitivity is only 0.016 (proton = 1). Therefore, the ${ }^{13} \mathrm{C}$ signal is $1.2 \times 10^{-5}$ weaker than that of ${ }^{1} \mathrm{H}$. For these reasons, ${ }^{13} \mathrm{C}$ atoms which do not carry a proton have very weak signals and are usually lost in the baseline.

As in proton NMR spectra, the low chemical shift region $(\delta=0$ to $40 \mathrm{ppm})$ is generally populated by saturated $\left(-\mathrm{CH}_{2}-\right.$, and $\mathrm{CH}_{3}-$ ) carbons, and the high chemical shift region $(\delta=110$ to $140 \mathrm{ppm})$ is populated by aromatic carbons. For ${ }^{13} \mathrm{C}$ spectra this is, however, an over simplification because ketone, aldehyde, and carboxylic acid carbons may be found at even higher chemical shifts ( $\delta=160$ to $220 \mathrm{ppm}$ ), and 
unsaturated carbons will overlap into the lower part of the aromatic region.

The major peak found in the $\mathrm{CDL}{ }^{13} \mathrm{C}$ spectra is centered at $29.6 \mathrm{ppm}$. Proton decoupling experiments show this peak to be due to methylene $\left(-\mathrm{CH}_{2}-\right)$, suggesting the presence of long chain hydrocarbons. The Usibelli CDL shows a carbon signal centered at $55.6 \mathrm{ppm}$. Decoupling experiments show this peak to be due to a $\mathrm{CH}_{3}-$, its chemical shift identifies the peak as a $\mathrm{CH}_{3}$ group bonded to a hetero atom, probably oxygen $\left(\mathrm{CH}_{3}-\mathrm{O}-\right)$.

\subsubsection{Commercial Testing and Engineering}

A sample of the CDL was sent to Commercial Testing and Engineering's (CTE) South Holland, IL laboratory for analysis. Table IX summarizes the results of these tests. Data sheets for these analysis may be found in Appendix I.

Table IX Commercial Testing and Engineering Blended CDL Analysis

\begin{tabular}{||l|l|r|}
\hline \multicolumn{1}{|c|}{ Method } & \multicolumn{1}{|c|}{ Analysis } & \multicolumn{1}{c|}{ Result } \\
\hline D 287 & Specific Gravity & 1.0244 \\
\hline D 240 & Heating Value, BTU/lb & 15,665 \\
\hline D 95 & Water, wt. \% & 0.08 \\
\hline D 473 & Sediment, wt. \% & 0.12 \\
\hline D 97 & Pour Point, $^{\circ} \mathrm{F}$ & 95 \\
\hline & Cold Point, $^{\circ} \mathrm{F}$ & 90 \\
\hline D 93 & Flash Point, ${ }^{\circ} \mathrm{F}$ & 225 \\
\hline Infrared & \% Carbon & 76.14 \\
\hline Infrared & \% Hydrogen & 8.72 \\
\hline TC & \% Nitrogen & 0.36 \\
\hline D 1552 & $\%$ Sulfur & 0.08 \\
\hline D 482 & \% Ash & 0.01 \\
\hline & $\%$ Oxygen (diff.) & 14.61 \\
\hline
\end{tabular}

CTE also conducted an atmospheric distillation analysis (D 86) of the CDL sample. The results of this analysis are provided in Table $X$.

\subsubsection{National Institute for Occupational Safety and Health (NIOSH)}

Samples of CDL were submitted to NIOSH for mutagenic testing. The NIOSH sample designation for Usibelli CDL is MRE 2. To summarize their results, Usibelli CDL was shown to be weakly mutagenic. The NIOSH report may be found in Appendix III. 
Table X Usibelli CDL Distillation Analysis

\begin{tabular}{||l|l||}
\hline $\begin{array}{l}\text { Percent } \\
\text { Distilled }\end{array}$ & $\begin{array}{l}\text { CTE } \\
\text { Atmospheric }\end{array}$ \\
\hline IPB & 212 \\
\hline 5 & 410 \\
\hline 10 & 432 \\
\hline 15 & 444 \\
\hline 20 & 474 \\
\hline 30 & 513 \\
\hline 40 & 549 \\
\hline 50 & 584 \\
\hline 60 & 599 \\
\hline 70 & 608 \\
\hline 80 & 564 \\
\hline 85 & 532 \\
\hline$\%$ Recovered & 84.5 \\
\hline
\end{tabular}

\subsection{Conclusions}

The co-product production runs conducted toward the end of February and the first of March 1993 have yielded sufficient simulated PDF and CDL to meet the production needs for the Alaskan Subbituminous Coal (Usibelli Mine). The analysis of the PDF suggests that the pyrolysis removed about $64 \%$ of the volatiles in the feed coal. This coal was very easy to process in the SPU and caused virtually no plugging of the down stream equipment.

The Usibelli coal is very low in sulfur $(0.15 \%)$. This blend would produce only $0.36 \mathrm{lbs} \mathrm{SO}_{2} f$ MMBTU when burned. During pyrolysis, some of the organic sulfur in the coal is removed with the volatiles.

The Usibelli PDF would produce $0.47 \mathrm{lbs} . \mathrm{SO}_{2} / \mathrm{MMBTU}$ when burned. This is consistent with the observed sulfur balance. During the SPU processing, $0.5 \mathrm{lbs}$. of sulfur was introduced; the resultant PDF, CDL, and noncondensable gases contained $0.46,0.02$, and 0.02 (by difference) lbs. of sulfur, respectively.

The overall yield of CDL was $7.1 \%$ based on the raw coal and $9.8 \%$ based on dry coal. The CDL is a low sulfur co-product containing only $0.08 \%$ sulfur by weight. The distillation curve in Figure 1 shows the $\mathrm{CDL}$ to be a heavier oil than normal crude, but the reasonably high molar $\mathrm{H} / \mathrm{C}$ ratio suggests that the co-product is refinable.

The NIOSH mutagenic testing determined that the Usibelli CDL is only weakly mutagenic. 


\section{Usibelli CDL Distillation Curve}

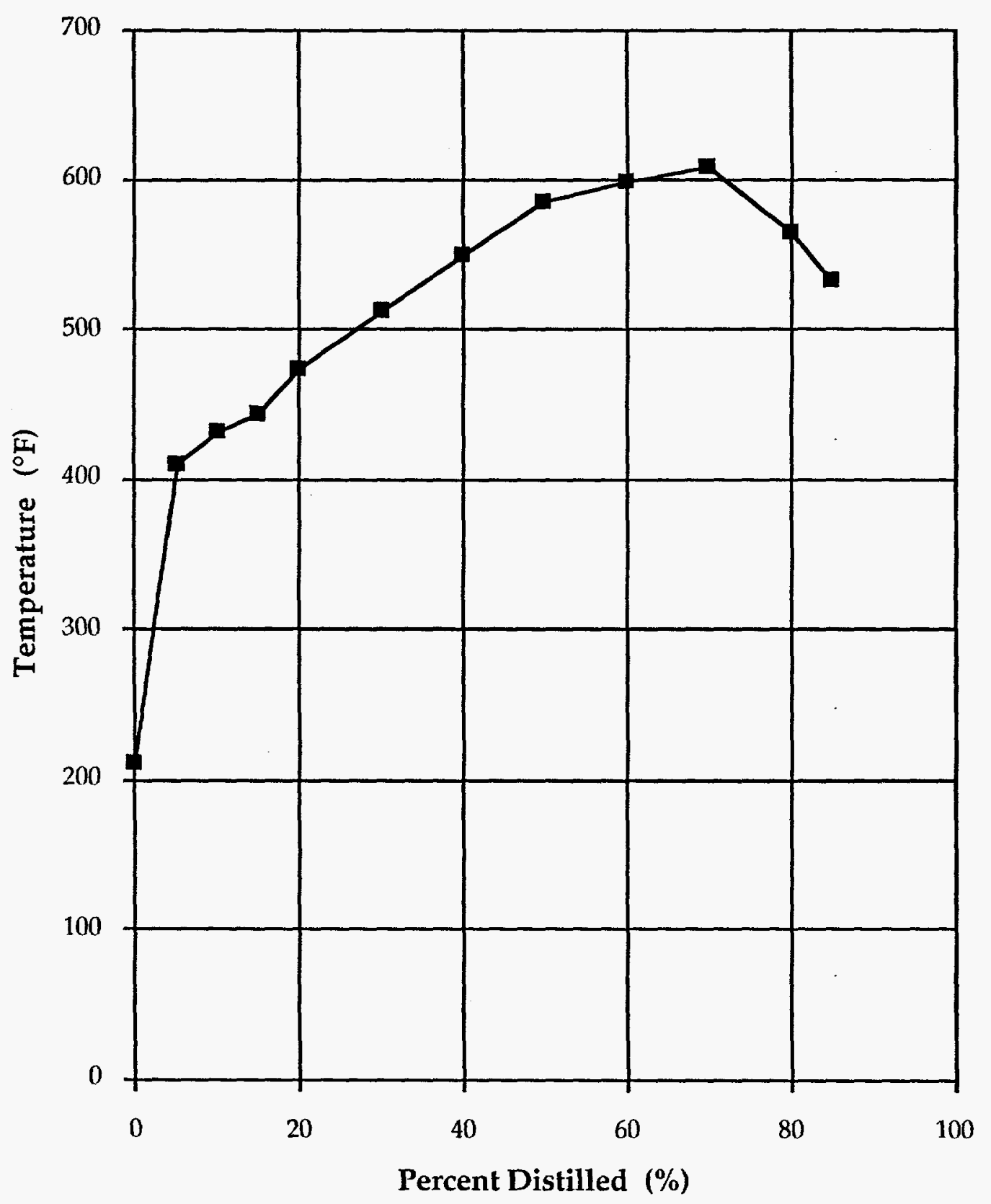

Figure 1. CDL Distillation Curve 
Appendix I Commercial Testing and Engineering Analysis Sheets 
April 14, 1993

SOUTH HOLLAND, IL 60473

TEL: (708) 331-2900

FAX: (708) 333-3060

MAUMEE RESEARCH \& ENGR., INC.

27457 Holiday Lane, Suite G

Perrysburg, OH 43551

Sample identification by

ATTN: Dr. Deane A. Home

Maumee Research \& Engr., Inc.

Kind of sample

reported to us Coal

Sample ID: UsibelIi Simulated PDF

Coal Char

Sample taken at

Sample taken by

Date sampled -...-

P.O. 04759

Date received March 29, 1993

Analysis Report No. 71-52412

Page 1 of 2

\section{PROXIMATE ANALYSIS}

\section{As Received}

\& Moisture

o Ash

\& Volatile

\& Fixed Carbon

Btu/Ib

\& Sulfur

MAF Btu

FORMS OF SULFUR

\& Pyritic

\& Sulfate

\& Organic (diff)

Total

$$
\begin{array}{r}
3.06 \\
10.39 \\
27.54 \\
59.01 \\
\hline 100.00
\end{array}
$$

11577

0.27

0.10

0.01

0.16

0.27
Dry Basis

$x \times x \times x$

10.72

28.41

60.87

100.00

11942

0.28

13376

\section{ULTIMATE ANALYSIS}

As Received

Dry Basis

\& Moisture

3.06

69.76

3.50

* Hydrogen

\& Nitrogen

1.13

\& Sulfur

0.27

\& Ash

\& Oxygen (diff)

10.39

$\frac{11.89}{100.00}$

$\mathrm{xxxxx}$

71.96

3.61

1.17

0.28

10.72

12.26

100.00

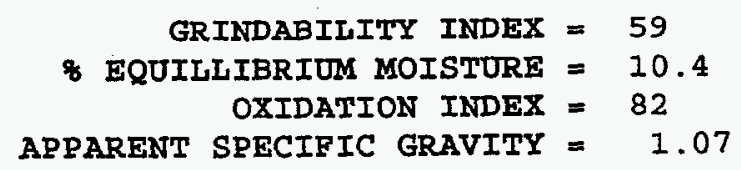

0.01

0.17 
April 14, 1993

MAUMEE RESEARCH \& ENGR., INC.

27457 Holiday Lane, Suite $G$

Perrysburg, OH 43551

ATTN: Dr. Deane A. Home

Sample identification by

Maumee Research \& Engr., Inc.

Kind of sample

reported to us Coal

Sample ID: Usibelli Simulated PDF

Coal Char

Sample taken at

Sample taken by

Date sampled -....

P.O. 04759

Date received March 29, 1993

Analysis Report No. 71-52412 Page 2 of 2

\section{METHODS}

Moisture: ASTM D 3302

Ash: ASTM D 3174

Volatile: ASTM D 3175

Fixed Carbon: Calculated Value; ASTM D 3172

Btu/lb: ASTM D 2015 or D 3286

Sulfur: ASTM D 4239 (Method C)

Chlorine: ASTM D 4208; Ion Selective Electrode or D 2361; Eschka

Fusion Temperature of Ash: ASTM D 1857

Fluorine: ASTM D 3761

Free Swelling Index: ASTM D 720

Hardgrove Grindability Index: ASTM D 409

Carbon and Hydrogen: Infrared Detection

Nitrogen: Thermal Conductivity

Forms of Sulfur: ASTM D 2492

Water Soluble Alkali: Digestion of the sample in $\mathrm{H}_{2} \mathrm{O}$ below

boiling point overnight followed by Atomic Absorption

Analysis of the Leachate

Acid Soluble Alkali: Digestion of the sample in Dilute HCL

below boiling point overnight followed by Atomic Absorption

Analysis of the Leachate

Oxidation Test: USX Method

Equilibrium Moisture: ASTM D 3180

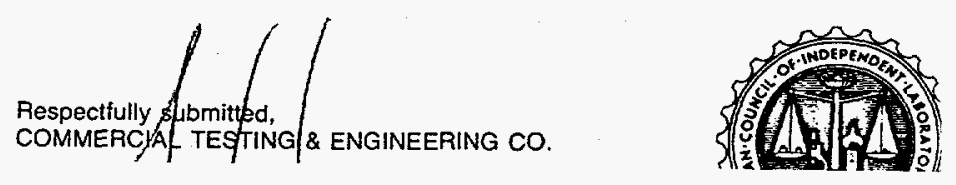


April 22, 1993

MAUMEE RESEARCH \& ENGR., INC.

27457 Holiday Lane, Suite G

Perrysburg, OH 43551

ATTN: Dr. Deane A. Home

Sample identification by

Maumee Research \& Engr., Inc.
Kind of sample

reported to us Coal

Sample taken at

Sample taken by

Date sampled -...-

Date received March 29, 1993
Sample ID: Raw Usibelli Coal

P.O. 04759

Analysis Report No. $\quad 71-52413$

Page 1 of 2

\section{PROXIMATE ANALYSIS}

As Received

\% Moisture

\& Ash

\& Volatile

\& Fixed Carbon

Btu/Ib

$$
\begin{array}{r}
25.15 \\
5.36 \\
32.55 \\
36.94 \\
\hline 100.00
\end{array}
$$

\& Sulfur

MAF Btu

FORMS OF SULFUR

\& Pyritic

\% Sulfate

\% Organic(diff)

Total
8284

0.15

.15

0.20

11921

11067

ULTIMATE ANALYSIS

Dry Basis

$x \times x x x$

7.16

43.49

49.35

100.00

$$
121
$$

7

8

\& Oxygen (diff)

\& Moisture

\% Carbon

\& Hydrogen

\% Nitrogen

is Sulfur

o Ash

As Received

Dry Basis

\subsection{5}

48.54

3.79

0.72

0.15

5.36

$\frac{16.29}{10.0 .00}$
$\operatorname{xxxxx}$
64.85
5.07
0.96
0.20
7.16
21.76
100.00


April 22, 1993

MAUMEE RESEARCH \& ENGR., INC.

27457 Holiday Lane, Suite G

Perrysburg, OH 43551

ATTN: Dr. Deane A. Home

Sample identification by

Maumee Research \& Engr., Inc.

Kind of sample

reported to us Coal

Sample ID: Raw Usibelli Coal

Sample taken at

Sample taken by

Date sampled .....

P.O. 04759

Date received March 29, 1993

$$
\text { Analysis Report No. 71-52413 }
$$

\section{METHODS}

Moisture: ASTM D 3302

Ash: ASTM D 3174

Volatile: ASTM D 3175

Fixed Carbon: Calculated Value; ASTM D 3172

Btu/1b: ASTM D 2015 or D 3286

Sulfur: ASTM D 4239 (Method C)

Hardgrove Grindability. Index: ASTM D 409

Carbon and Hydrogen: Infrared Detection

Nitrogen: Thermal Conductivity

Forms of Sulfur: ASTM D 2492

Oxidation Test: USX Method

Equilibrium Moisture: ASTM D 3180 
April 5, 1993

MAUMEE RESEARCH \& ENGR., INC.

27457 Holiday Lane, Suite G

Perrysburg, OH 43551

ATTN: Dr. Deane A. Home

Sample identification by

Maumee Research \& Engr., Inc.

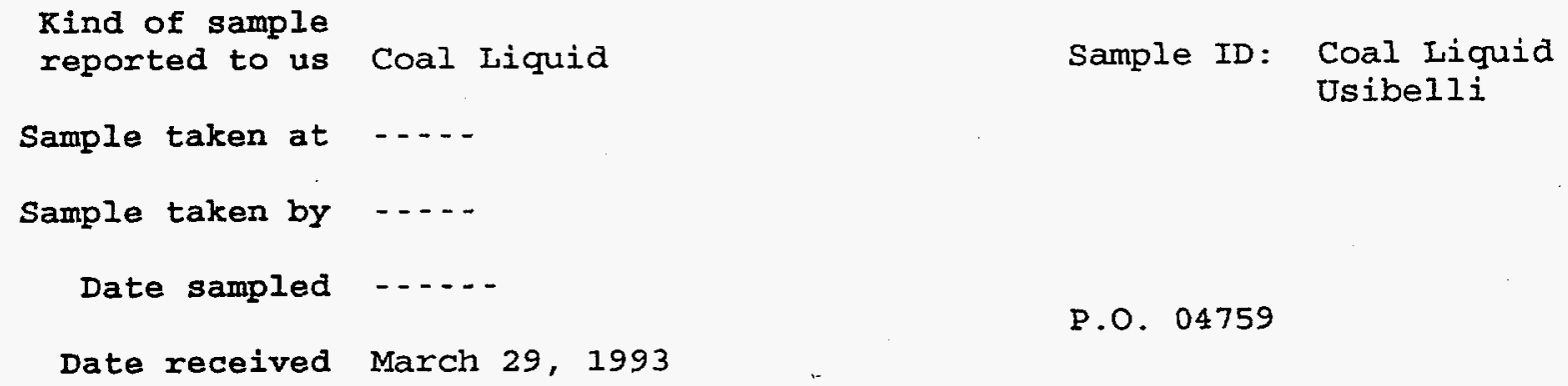

Analysis Report No. 71-52414

As Received

$\begin{array}{lcc}\begin{array}{c}\text { DISTILIATION, } \\ \text { INITIAL BOILING POINT, } \%\end{array} & 212 \\ & 5 & \\ & 10 & 410 \\ & 15 & 432 \\ & 20 & 444 \\ & 30 & 474 \\ & 40 & 513 \\ & 50 & 549 \\ & 60 & 584 \\ \quad 70 & 599 \\ & 80 & 608 \\ \text { END POINT } & 84.5 & 564 \\ \text { RECOVERY } & & 532 \\ \text { RESIDUE } & & * \\ \text { IOSS } & & 84.5 \\ & & 15.5 \\ & & 0.0\end{array}$

METHOD

Distillation: ASTM D 86

* Oil Brake 
Apri1 5, 1993

MAUMEE RESEARCH \& ENGR., INC.

27457 Holiday Lane, Suite G

Perrysburg, OH 43551

Sample identification by

ATTN: Dr. Deane A. Home

Maumee Research \& Engr., Inc.

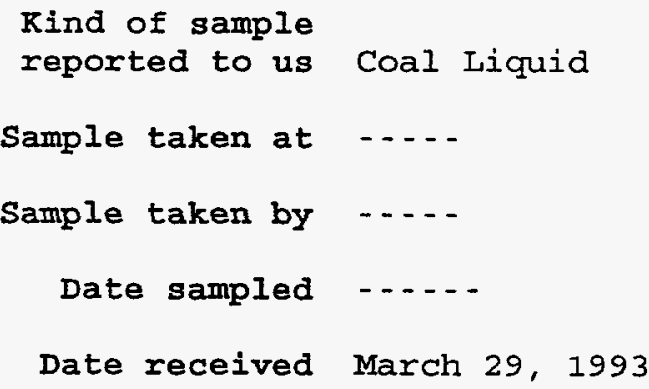

Sample ID: Coal Liquid

Usibelli

\section{Analysis Report No. $\quad 71-52414$}

Page 2 of 3

\section{As Received}

GRAVITY

Specific at $60 / 600^{\circ}$
Lb/gallon at $60 \% \mathrm{~F}$
OAPI
HETING VALUE

1.0244

8.534

6.6

Btu/gal at $60 \% \mathrm{~F}$

SEDIMENT, \& Wt.

POUR POINT, OF

COLD POINT

15,665

133,685

0.12

$+95$

$+90$

FLASH POINT, OF

CLEVELAND OPEN CUP

225

\section{METHODS}

Gravity: ASTM D 287

Heating Value: ASTM D 240

water: ASTM D 95

Sediment: ASTM D 473

Pour Point: ASTM D 97

Flash Point: ASTM D 93 
April 5, 1993

MAUMEE RESEARCH \& ENGR., INC.

27457 Holiday Lane, Suite G

Perrysburg, OH 43551

ATTN : Dr. Deane A. Home

Sample identification by

Maumee Research \& Engr., Inc.

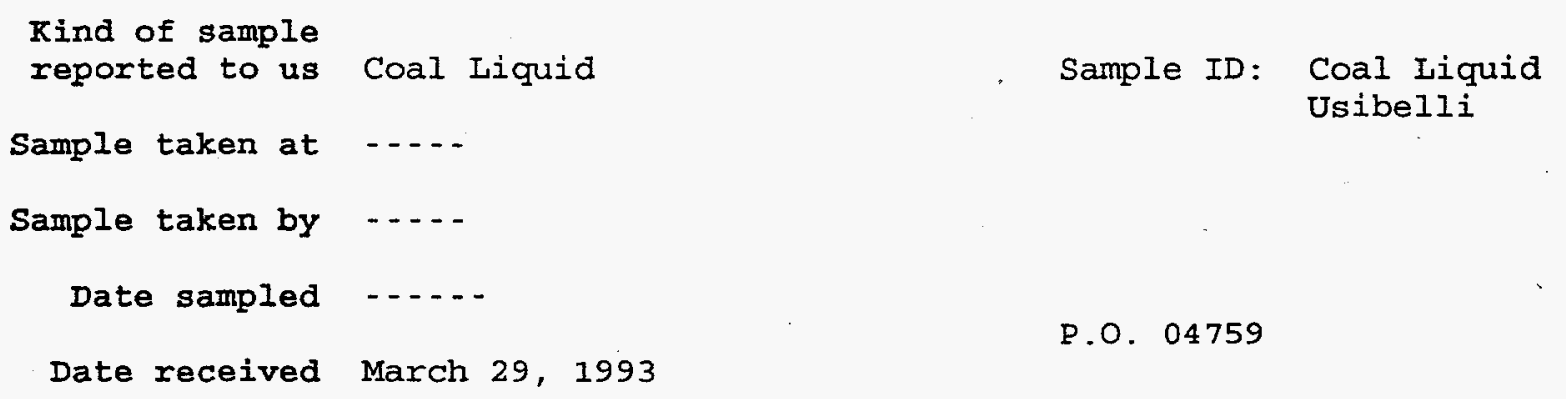

Analysis Report No. 71-52414 Page 3 of 3

ULTIMATE ANALYSIS

As Received

\& Water
\& Carbon
\& Hydrogen
\& Nitrogen
\& Sulfur
\& Ash
\& Oxygen (diff)

Btu/1b
0.08

76.14

8.72

0.36

0.08

0.01

$\frac{14.61}{100.00}$

15665

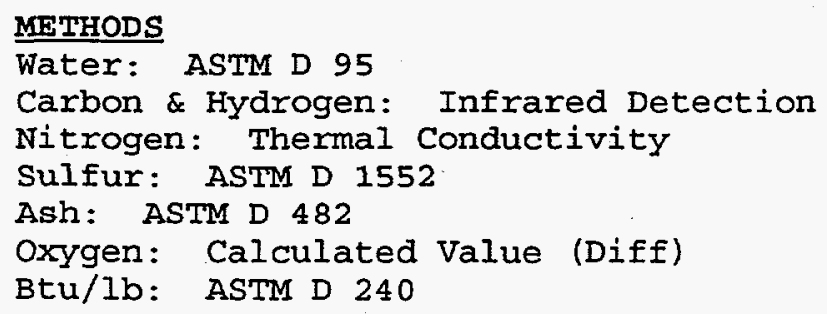


Appendix II ${ }^{13} \mathrm{C}$ and ${ }^{1} \mathrm{H}$ NMR Spectra of CDL 


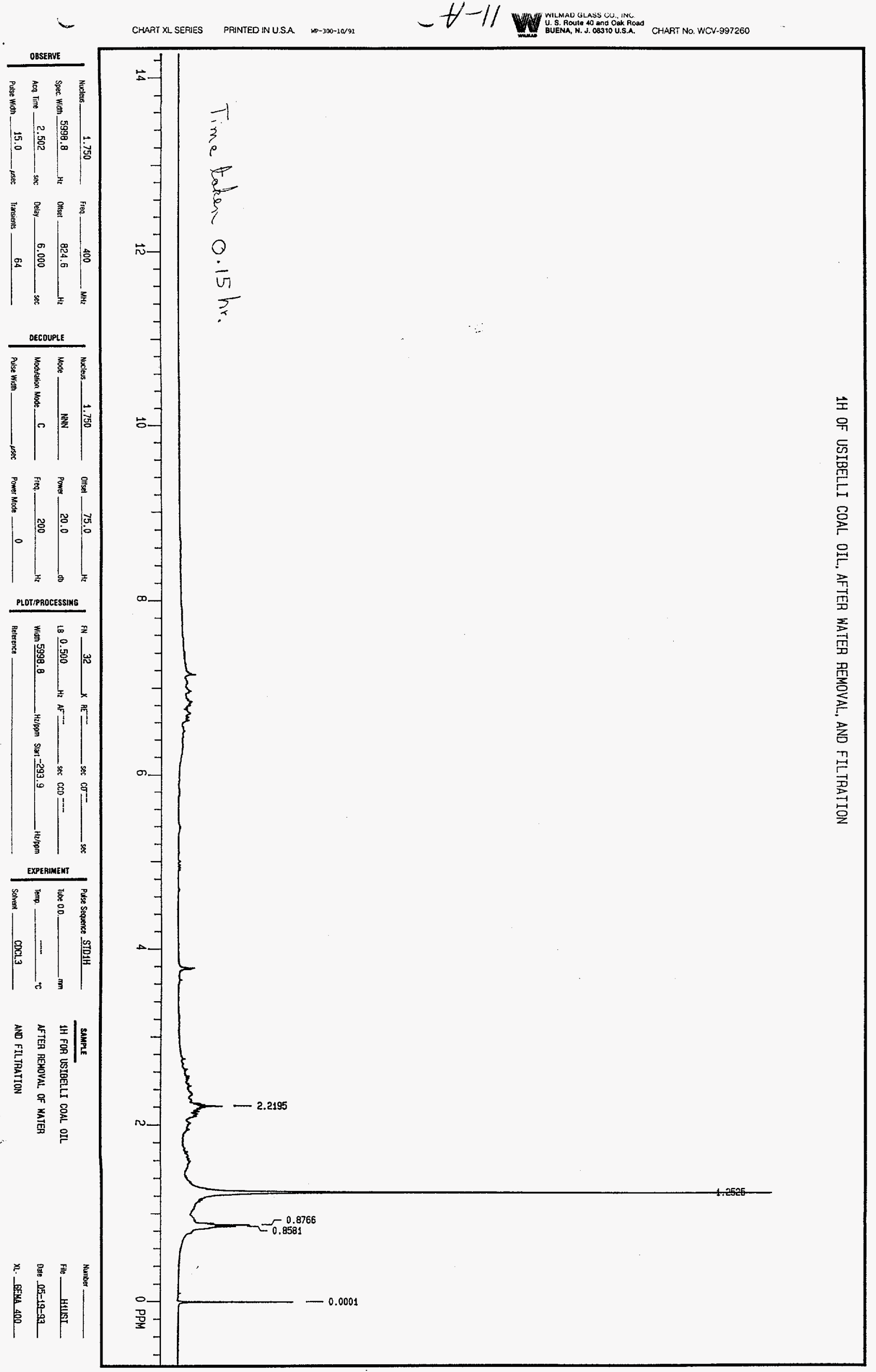




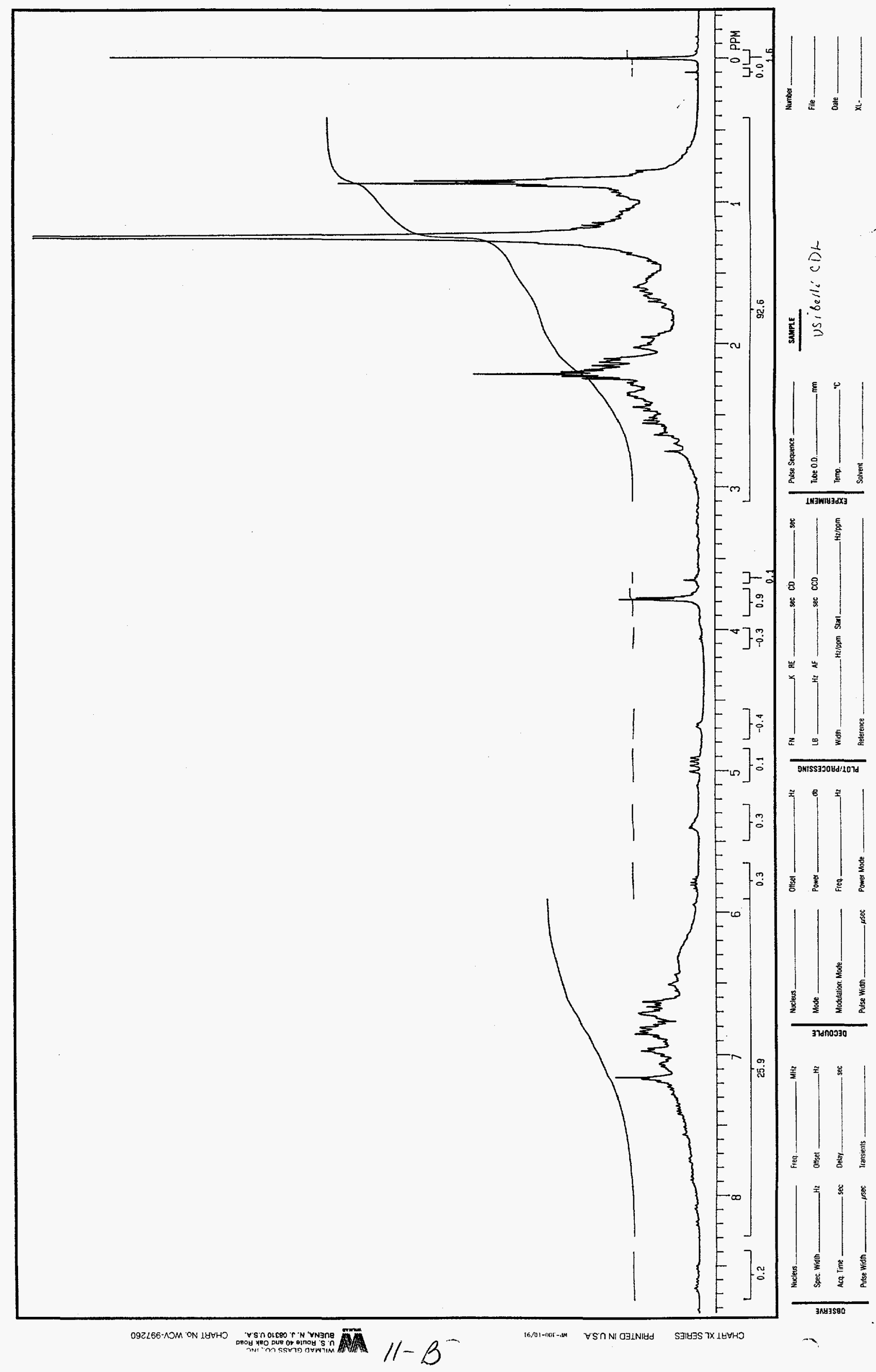




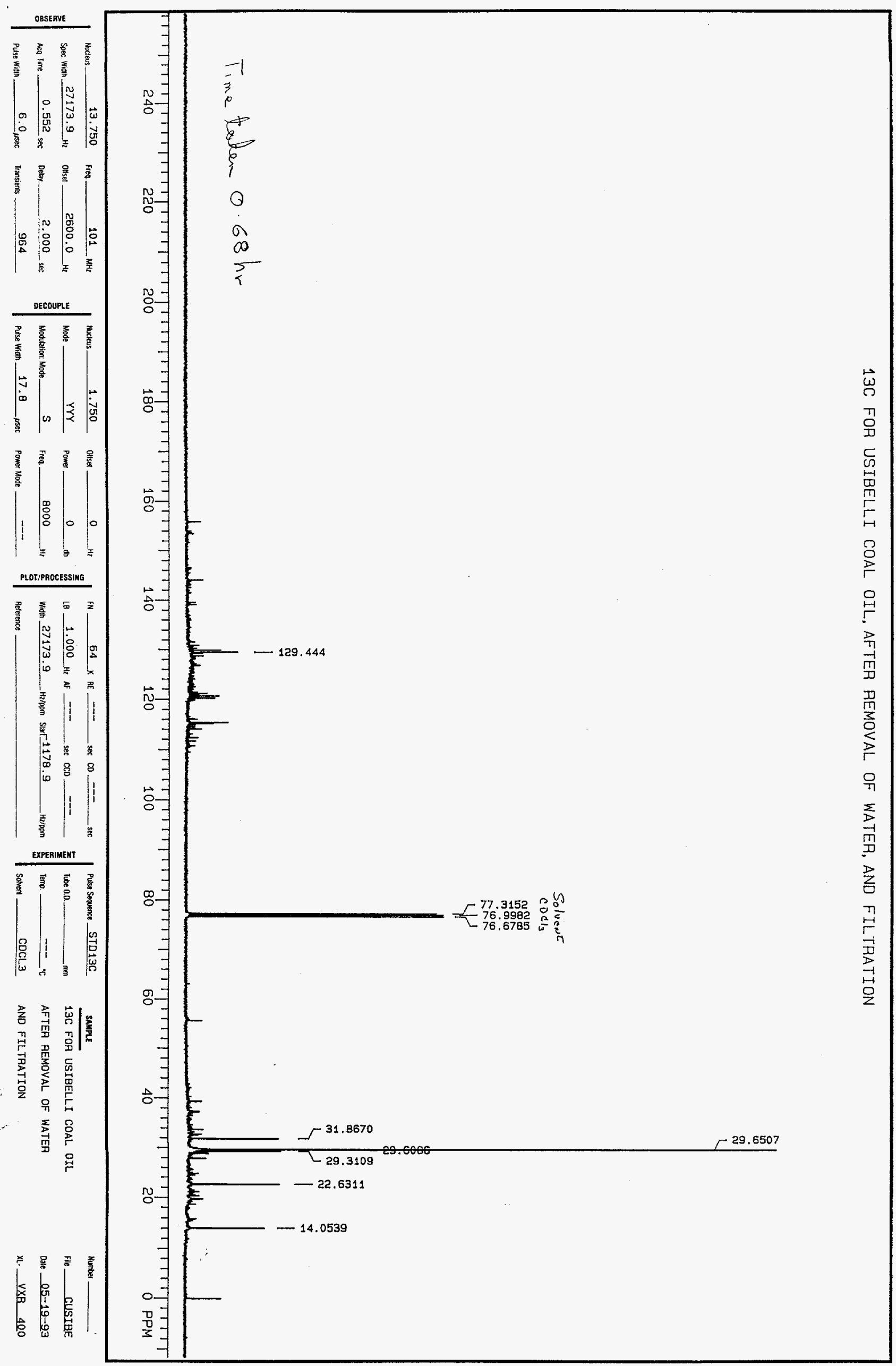


Appendix III National Institute for Occupational Safety and Health Data Sheets 
Centers for Disease Control National Institute for Occupational Safety and Health - ALOSH 944 Chestnut Ridge Road Morgantown, WV 26505-2888

November 1, 1993

Deane A. Horne, Ph.D.

Maumee Research and Engineering, Inc.

27457 Holiday Lane, Suite G

Perrysburg, OH 43551

Dear Dr. Horne,

The enclosed three reports contain the results of genotoxicity studies conducted by NIOSH on the four coal-derived liquid fuel samples received from Maumee Research and Engineering. Inc. (reference: Contract No. DE-AC21-91MC27240), per your request by telephone today.

Our designation of the samples is as follows:

CL201 Buckskin, Powder River Basin

MRE 1 Sarpy Creek, Rosebud Seam

MRE 2 Usibelli (Alaska)

MRE 3 Knife River, Williston Basin

If you have any questions about the reports, please let us know.

Sincerely,

Lusax B. Robbixs

Susan B. Robbins

Microbiology Section

Division of Respiratory Disease Studies

Enc1.: Mutagenicity of CL201 in the Ames Assay

Mutagenicity of MRE 1, MRE 2, and MRE 2 in the Ames Assay

The Genotoxicity Studies of Mild Gasification Product MRE 1 in Mammalian Cells 


\section{Mutagenicity of MRE 1, MRE 2, and MRE 3 in the Ames Assay}

\section{INTRODUCTION}

Mild gasification of coal is a technology being developed by the United States Department of Energy (DOE) and private industry with the hope that a cleaner method of coal use can help meet future energy needs. As the technology develops and its commercial use becomes a more viable possibility, efforts are being made to study the safety and possible toxicity of the mild gasification products. DOE and the National Institute for Occupational Safety and Health (NIOSH) are cooperating through an interagency agreement to examine some of these products for their genotoxic potential.

NIOSH has studied the mutagenicity of several mild gasification product samples using the Ames Salmonella microsomal assay (Maron and Ames, 1983). The Ames assay is widely used as a short-term test for the detection of possible genotoxic agents and potential carcinogens. Bacterial tester strains used in the Ames assay contain specific mutations (frameshift or base pair substitution) that cause the bacteria to be dependent on growth medium containing the amino acid histidine. The mutagenic activity of a test substance is measured by the number of reverse mutations eliminating the histidine requirement. Mutation is generally accepted to be involved in the initiation stage of carcinogenesis; therefore, the Ames assay has often been used as the first tier of testing in the evaluation of long-term health risks associated with exposure to certain chemicals.

\section{METHODS AND MATERIALS}

Sample description

MRE 1 has a liquid/tar consistency and a boiling point of $216^{\circ} \mathrm{F}$. The sample was made from a 50:50 mix of low- and high-sodium Montana coal and obtained from Maumee Research and Engineering, Inc. (MRE).

MRE 2 has a liquid/tar consistency, with a boiling point of $212^{\circ} \mathrm{F}$. It was made from Alaskan coal and obtained from MRE.

MRE 3 also has a liquid/tar consistency, with a boiling point of $212^{\circ} \mathrm{F}$. The sample was made from North Dakota lignite coal and obtained from MRE.

\section{Chemicals}

Positive controls:

2-aminoanthracene (2AA), a chemical mutagen which requires metabolic activation (+S9), and trinitrofluorenone (TNF), a direct acting mutagen (-S9), were used in the assay system at final concentrations of $2.5 \mu \mathrm{g} / \mathrm{plate}$ and $0.4 \mu \mathrm{g} /$ plate, respectively. Both were purchased from Aldrich Chemical Company, Milwaukee, Wisconsin. 
Solvent control:

Dimethylsulfoxide (sterile, spectrophotometric grade) was purchased from EM Science, Cherry Hill, New Jersey.

\section{Sample preparation}

The sample was dissolved in DMSO to the desired concentrations, using methodologies similar to those described by $\mathrm{Ma}$ et al. (1983). The mixture was heated to $50^{\circ} \mathrm{C}$ and sonicated in a Branson model 3200 water bath/sonicator for 30 minutes to facilitate homogenization. The mixture was warmed, sonicated, and vortexed until a homogeneous solution was obtained. Lower concentrations of each sample was obtained by serial dilution of the original solution. The positive controls were prepared in a manner similar to the sample to ensure consistent experimental design.

\section{Ames Salmonella microsomal Assay}

The mutagenicity of each sample was determined using the pre-incubation variant of the Ames Salmonella microsomal assay system (Maron and Ames, 1983), which is frequently more sensitive than the standard protocol. The sample was tested on TA98 and TA100 bacterial tester strains. Each concentration on each tester was tested with and without metabolic activation by S9, a preparation made from the livers of Aroclor 1254-treated male Wistar rats. Each of these treatments was tested in triplicate. In a test tube, $0.1 \mathrm{ml}$ of the sample or a control chemical was combined with $0.1 \mathrm{ml}$ overnight bacterial culture and 0.5 $\mathrm{ml}$ S9 preparation or $0.5 \mathrm{ml}$ physiological saline. Each test tube was vortexed and incubated on a rotary shaker at $37^{\circ} \mathrm{C}$ for 30 minutes prior to adding $2.5 \mathrm{ml}$ molten $\left(45^{\circ} \mathrm{C}\right)$ top agar and pouring the mixture onto a petri dish. After the top agar solidified, the dishes were inverted and incubated for 48 hours at $37^{\circ} \mathrm{C}$. The top agar contained a trace amount of histidine which is required for initial bacterial growth. After several rounds of cell division, the histidine present was depleted. Only those bacteria that had mutated to be histidineindependent continued to grow and form a colony. Those bacteria are called revertants because they have reverted (in that trait only) back to the wild-type Salmonella. The revertant colonies were scored on an automatic colony counter. The criteria for positive mutagenic activity in the Ames assay is a doubling of the solvent control in the number of revertants, accompanied by a dose-related increase in revertant numbers. The positive controls allow us to be certain that the bacteria grew and the S9 worked properly.

\section{RESULTS AND DISCUSSION}

MRE 1 displayed consistant, reproducable mutagenic activity in TA98 in the presence of S9 metabolic activation. The number of revertant colonies was three to four fold higher than that of the solvent control. The sample also displayed some doubling of the solvent control in TA100 with S9 (Table 1), but that activity could not be confirmed and therefore is not considered to be positive. MRE 2 and MRE 3 also displayed some doubling of the solvent

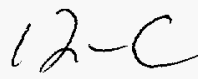


control activity on TA98 with S9, but less so than MRE 1 . The dose-response in those two samples was less obvious as well as inconsistent.

The histidine dependence in TA98 is due to a frameshift mutation, which skews the reading frame of the genetic code, while the histidine dependence in TA100 may be due to a frameshift mutation or a base-pair substitution. The reversion of either mutation requires another event of the same type mutation, so the evidence of mutagenic activity in TA98, and less so in TA100 indicates that the samples most likely contain frameshift mutagens. The fact that the activity is only present when $S 9$ is added and not without $S 9$ indicates that the samples require metabolic activation, in which case mutagens present are referred to as indirect-acting mutagens.

Based on this study, it appears that MRE 1 is mutagenic, probably inducing frameshift mutations after metabolic activation. MRE 2 and MRE 3 are weakly mutagenic, most likely containing indirect-acting frameshift mutagens.

\section{REFERENCES}

Ma, C.Y., C.H. Ho, R.B. Quincy, M.R. Guerin, T.K. Rao, B.E. Allen, and J.L. Epler (1983) Preparation of oils for bacterial testing, Mutat. Res., 118:15-24.

Maron, D.M., and B.N. Ames, 1983. Revised methods for the Salmonella mutagenicity test. Mutat Res, 113:173-215. 
TABLE I

Mutagenicity Testing of MRE 1, MRE 2, and MRE 3

\begin{tabular}{|c|c|c|c|c|c|}
\hline \multirow{3}{*}{ Sample } & \multirow{3}{*}{$\begin{array}{c}\text { Concentration } \\
\mu \mathrm{g} / \text { plate }\end{array}$} & \multicolumn{4}{|c|}{ Average Number of Revertant Colonies per Plate } \\
\hline & & \multicolumn{2}{|c|}{ TA 98} & \multicolumn{2}{|c|}{ TA 100} \\
\hline & & - S9 & +59 & - S9 & $\begin{array}{r}+59 \\
\end{array}$ \\
\hline \multirow{7}{*}{ MRE 1} & $0^{\mathrm{A}}$ & 22 & 28 & 86 & 102 \\
\hline & 15.6 & 37 & $-{ }_{-}^{B}$ & - & - \\
\hline & 31.25 & 36 & $76^{*}$ & 135 & 167 \\
\hline & 62.5 & 30 & $96^{*}$ & 151 & 169 \\
\hline & 125 & $19^{\mathrm{C}}$ & $96^{*}$ & 129 & 222 \\
\hline & 250 & - & $101^{*}$ & $46^{\mathrm{C}}$ & 211 \\
\hline & 500 & - & - & - & 140 \\
\hline \multirow[t]{7}{*}{ MRE 2} & $0^{\mathrm{A}}$ & 22 & 28 & 86 & 102 \\
\hline & 31.25 & 33 & 41 & - & - \\
\hline & 62.5 & 33 & $66^{*}$ & 109 & - \\
\hline & 125 & 28 & $58^{*}$ & 141 & 168 \\
\hline & 250 & $19^{\mathrm{c}}$ & 54 & $89^{C}$ & 161 \\
\hline & 500 & - & 47 & $50^{C}$ & 188 \\
\hline & 1000 & - & - & - & 113 \\
\hline \multirow[t]{7}{*}{ MRE 3} & $0^{A}$ & 22 & 28 & 86 & 102 \\
\hline & 15.6 & 40 & - & - & - \\
\hline & 31.25 & 41 & - & 111 & - \\
\hline & 62.5 & $19^{c}$ & 50 & 137 & 111 \\
\hline & 125 & $1^{\mathrm{C}}$ & $68^{*}$ & 125 & 157 \\
\hline & 250 & - & $63^{*}$ & $48^{\mathrm{C}}$ & 213 \\
\hline & 500 & - & $77^{*}$ & - & 194 \\
\hline \multirow[t]{2}{*}{$2 \mathrm{AA}$} & $0^{A}$ & 22 & 28 & 86 & 102 \\
\hline & 2.5 & - & 1176 & - & 1787 \\
\hline \multirow[t]{2}{*}{ TNF } & $0^{\mathrm{A}}$ & 22 & 28 & 86 & 102 \\
\hline & & 980 & - & - & - \\
\hline
\end{tabular}

${ }^{\text {A }}$ DMSO solvent control ${ }^{\mathrm{B}}$ Not tested ${ }^{\mathrm{C}}$ Too much cytotoxicity ${ }^{*}$ Positive response 


\section{APPENDIX D}

SAMPLE PRODUCTION REPORT FOR KNIFE RIVER (WILLISTON BASIN) COAL FOR "PRODUCTION OF MILD GASIFICATION CO-PRODUCTS" PROJECT

Topical Report (FINAL)

By:

D. A. Horne

J. C. Castro

December 4, 1994

Work Performed Under Contract NO.: DE-AC21-91MC27240

For:

U.S. Department of Energy

Morgantown Energy Technology Center

Morgantown, West Virginia

By:

SGI Fuels, Incorporated

La Jolla, California 


\section{EXECUTIVE SUMMARY}

Six (6) 55 gallon barrels of Knife River lignite coal were sampled from three seams at the Knife River Mine located in the Williston basin near the town of Beulah, North Dakota, on 10 August 1992. These samples were crushed and sized to $-5 / 8 "+1 / 4$ " for processing to produce Liquids From Coal (LFC) liquid and solid co-products. A total of $472 \mathrm{lbs}$. of raw coal was processed through SGI's Sample Production Unit (SPU) producing $180 \mathrm{lbs}$ of simulated Process Derived Fuel (PDF) and 20.9 lbs. of Coal Derived Liquid (CDL) co-products. Testing results show that the processing upgraded the coal by removing the water from the coal (33\% by weight), increasing its heating value from 7,367 to $11,940 \mathrm{BTU} / \mathrm{lb}$. The sulfur analysis for this coal and its resulting PDF shows a net decrease in the pounds of $\mathrm{SO}_{2}$ per million $\mathrm{BTU}$ (3.7 and $2.3 \mathrm{lbs}$. $\mathrm{SO}_{2} / \mathrm{MMBTU}$ for the feed coal and PDF respectively). The $\mathrm{SO}_{2}$ emission rates for both the PDF and ROM coal are above clean air act limits.

The CDL has properties similar to tar sand oil with a pour point in the $65^{\circ}$ to $100^{\circ} \mathrm{F}$ range. The specific gravity of the oil is near 1.08 giving an API gravity of $-0.7^{\circ}$. Most of the hydrogen compounds in the $\mathrm{CDL}$ are involved in paraffinic structures $\left(-\mathrm{CH}_{2}-\right)$. The $\mathrm{CDL}$ has a molar $\mathrm{H} / \mathrm{C}$ ratio of 1.20. This compares to 2.2 for simple paraffins, and 0.8 for naphthalene.

The CDL is only weakly mutagenic as determined by NIOSH. 


\section{TABLE OF CONTENTS}

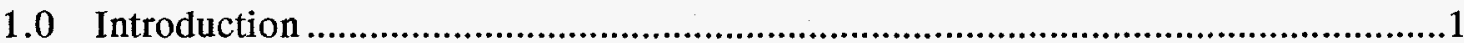

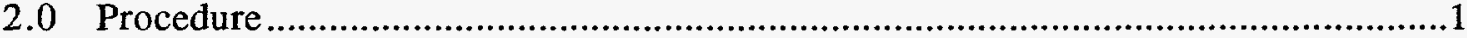

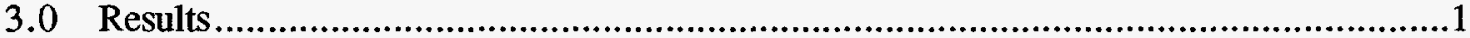

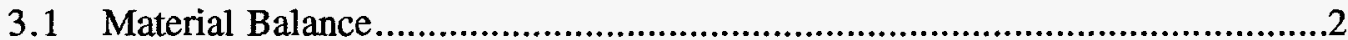

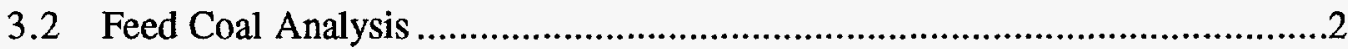

3.2.1 SGI Development Center ................................................................2

3.2.2 Commercial Testing and Engineering Analysis..................................

3.3 Simulated PDF Analysis.......................................................................

3.3.1 SGI Development Center ........................................................4

3.3.2 Commercial Testing and Engineering Analysis...............................4

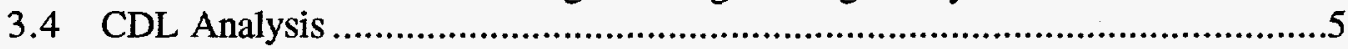

3.4.1 SGI's Development Center, NMR Analysis ......................................5

3.4.2 Commercial Testing and Engineering ...........................................7

3.4.3 National Institute of Occupational Safety and Health (NIOSH) ......7

4.0 Conclusions .8

Appendix I Commercial Testing and Engineering Analysis Sheets.....................................10

Appendix II ${ }^{13} \mathrm{C}$ and ${ }^{1} \mathrm{H}$ NMR Spectra of CDL.........................................................11

Appendix III National Institute for Occupational Safety and Health Data Sheets...............12 


\section{TABLES}

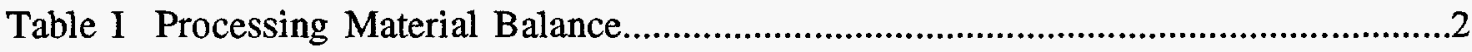

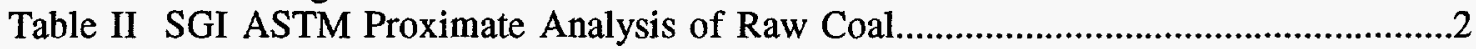

Table III CTE Raw Coal Proximate and Ultimate Analysis Results......................................3

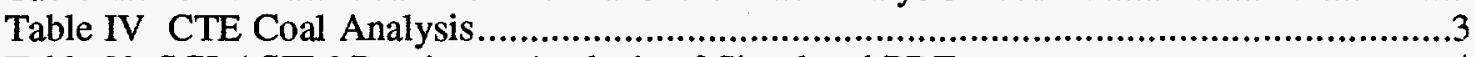

Table V SGI ASTM Proximate Analysis of Simulated PDF ....................................4

Table VI CTE Simulated PDF Proximate and Ultimate Analysis Results........................4

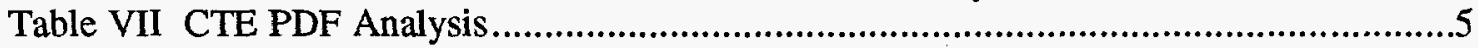

Table VIII Proton NMR Peak Areas..............................................................................6

Table IX Commercial Testing and Engineering Blended CDL Analysis ...........................7

Table X Knife River CDL Distillation Analysis............................................................8

\section{FIGURES}

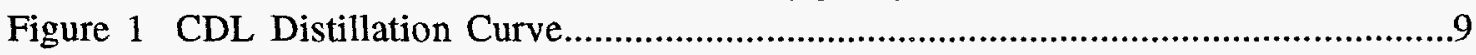




\subsection{Introduction}

The Liquids From Coal (LFC) Process, developed by SGI International, employs a mild gasification procedure to produce two co-products, a Coal Derived Liquid (CDL) and a solid Process Derived Fuel (PDF). The CDL is formed from the condensation of volatile matter removed from the coal during the LFC Process, and the PDF is the remaining solid product after most of the moisture and some of the volatile matter have been removed. In an effort to examine and classify these two mild gasification co-products, SGI Fuels, Inc. entered into an agreement with the Morgantown Energy Technology Center (METC) to produce liquid and solid co-product samples using the LFC Process on four (4) coals from three major coal resource regions in the United States. Those regions were designated to be the Powder River Basin, the Williston Basin, and Alaska. The purpose of this report is to describe the procedure of processing Knife River lignite (from the Williston Basin) to produce solid and liquid co-products and to identify the characteristics of the co-products. Knife River lignite was obtained from the Knife River Mine located south of the town of Beulah, North Dakota.

\subsection{Procedure}

Samples of coal were taken from freshly mined faces of three different seams. Sampling starting at about 1:00 PM on 10 September 1992. At the time of sampling, the sky was clear, and the temperature was about $60^{\circ} \mathrm{F}$. The samples were packaged in 55 gallon polyethylene drums with sealing lids for shipment to the SGI Development Center. After receipt of the samples at the Development Center, the coal was prepared for processing by crushing and sizing to $-5 / 8+1 / 4$ inch. Coal samples were prepared and packaged in sealed 5 gallon plastic pails for later shipment to laboratories for analysis and testing.

The sized coal was dried in the Sample Production Unit (SPU) and then allowed to cool in sealed stainless steel containers. Once the dried coal was cool, it was stored under nitrogen in sealed 5 gallon plastic pails for later pyrolysis in the SPU.

The dried coal was pyrolyzed in the SPU and then allowed to cool in sealed stainless steel containers in the same manner as the dry coal. After the coal had cooled to about room temperature, it was spread in a thin layer on a plastic sheet to partially oxidize the char. Water was then sprayed in a fine mist to partially rehydrate the char to produce simulated PDF. The water was preweighed so that $5 \%$ moisture would be added to the char.

During the pyrolysis runs, the CDL was collected in an electrostatic precipitator (ESP) operating at 30,000 volts in a constant current mode. To condense oil and not water, the ESP was maintained at $130^{\circ} \mathrm{F}$, above the dew point of water. The CDL was removed from the ESP by gravity and stored in sealed one liter borosilicate glass bottles.

During these standard sequences, no attempt was made to optimize the mild pyrolysis process with the heat rate, peak temperatures, or heating duration. The LFC Process, the SPU, and the ENCOAL Demonstration plant at Gillette, WY, are sufficiently flexible to produce co-products with a wide range of characteristics to meet the end users requirements.

\subsection{Results}

The coal was crushed and sized on 17 September 1992. Processing started on 20 September 1992, and sized coal was dried over a period of six (6) days. After drying, the coal was pyrolyzed starting on 28 September 1992. This coal proved difficult to dry and pyrolyze in the SPU. The flat aspect ratio and the low density of the dried coal combined to produce significant gas flow resistance. At flow rates used for most coals, the bed was lifted out of the reactor. Consequently, to apply the LFC Process to the Knife River lignite, the process gas flow rate had to be reduced by about $20 \%$ from standard levels to keep the coal in the SPU's reaction chamber. 


\subsection{Material Balance.}

During these runs, a total of 472 pounds of raw coal was processed yielding 293 pounds of dry coal. The dry coal was pyrolyzed to yield 180 pounds of char and 20.9 pounds of CDL. Table I summarizes the material balance.

Table I Processing Material Balance

\begin{tabular}{||l|r||}
\hline \multicolumn{1}{|c|}{ Material } & \multicolumn{1}{c|}{ Total } \\
\hline Raw Coal, lbs. & 472 \\
\hline Dry Coal, lbs. & 293 \\
\hline Moisture (by difference), lbs & 179 \\
\hline Dry Feed, lbs. & 293 \\
\hline Char, lbs. & 180 \\
\hline Fines, lbs. & 16.9 \\
\hline CDL, lbs. & 20.9 \\
\hline $\begin{array}{l}\text { Gas and Light hydrocarbons } \\
\text { (by difference), lbs }\end{array}$ & 75.2 \\
\hline
\end{tabular}

\subsection{Feed Coal Analysis}

A Proximate analysis of the feed coal was conducted at the Development Center. Samples of feed coal also were sent to Commercial Testing and Engineering, Inc., for analysis.

\subsubsection{SGI Development Center}

Table II summarizes the results of the Development Center's Proximate analysis and heat of combustion determination for the feed coal.

Table II SGI ASTM Proximate Analysis of Raw Coal

\begin{tabular}{||l|r|r|}
\hline & \multicolumn{1}{|c|}{ Raw Coal } & Bone Dry Basis \\
\hline Moisture & 33.53 & -- \\
\hline Volatiles & 28.65 & 43.10 \\
\hline Fixed Carbon & 33.38 & 50.22 \\
\hline Ash & 4.44 & 6.68 \\
\hline BTU/lb & 7,000 & 10,531 \\
\hline
\end{tabular}

\subsubsection{Commercial Testing and Engineering Analysis.}

A sample of sized raw coal was sent to Commercial Testing and Engineering, Inc. in 
South Holland, $\mathrm{IL}$ for Proximate analysis, Ultimate analysis, and associated tests to determine forms of sulfur, grindability, percent equilibrium moisture, and apparent specific gravity. Table III summarizes the results for the Proximate and Ultimate analysis including the heat of combustion. Data sheets for this analysis may be found in Appendix I.

Table III CTE Raw Coal Proximate and Ultimate Analysis Results

\begin{tabular}{||l|l|r|r||}
\hline \multicolumn{1}{|c|}{ Method } & \multicolumn{1}{|c|}{ Sample } & Raw Coal & Bone Dry Basis \\
\hline D 3302 & \% Moisture & 32.65 & -- \\
\hline D 3175 & \% Volatiles & 29.46 & 43.74 \\
\hline D 3172 & \% Fixed Carbon & 30.96 & 45.97 \\
\hline D 3174 & \% Ash & 6.93 & 10.29 \\
\hline Infrared & \% Carbon & 42.79 & 63.53 \\
\hline Infrared & \% Hydrogen & 3.20 & 4.75 \\
\hline TC & \% Nitrogen & 0.84 & 1.24 \\
\hline D 4239 & \% Sulfur & 1.37 & 2.03 \\
\hline D 2015 & Heat of Combustion, BTU/1b & 7,367 & 10,939 \\
\hline
\end{tabular}

Other coal properties such as forms of sulfur, grindability, equilibrium moisture, and apparent specific gravity, as determined by CTE, are summarized in Table IV.

Table IV CTE Coal Analysis

\begin{tabular}{||l|l|c|c||}
\hline \multicolumn{1}{|c|}{ Method } & \multicolumn{1}{c|}{ Analysis } & \multicolumn{2}{c|}{ Raw Coal } \\
\hline D 2492 & \multicolumn{1}{|c|}{ Forms of Sulfur } & A.R. & B.D. \\
\hline & \% Pyritic & 0.65 & 0.97 \\
\hline & \% Sulfate & 0.01 & 0.01 \\
\hline & \% Organic (diff) & 0.71 & 1.05 \\
\hline & \multicolumn{1}{|c|}{ Total } & 1.37 & 2.03 \\
\hline D 409 & Grindability & \multicolumn{2}{|c|}{47} \\
\hline D 3180 & \% Equilibrium $\mathrm{H}_{2} \mathrm{O}$ & \multicolumn{2}{|c|}{33.8} \\
\hline USX Method & USX Oxidation Index & \multicolumn{2}{|c|}{1.33} \\
\hline & Apparent S.G. (g/cc) & \multicolumn{2}{|c|}{} \\
\hline
\end{tabular}

Based on the CTE analysis, the sulfur dioxide emission for the raw coal is $3.71 \mathrm{lbs}$ $\mathrm{SO}_{2}$ /MMBTU. 


\subsection{Simulated PDF Analysis}

A Proximate analysis of the simulated PDF was conducted at the Development Center. Samples of the PDF also were sent to Commercial Testing and Engineering, Inc. for analysis.

\subsubsection{SGI Development Center}

Table V summarizes the results of the Development Center's Proximate analysis and heat of combustion determination for the PDF.

Table V SGI ASTM Proximate Analysis of Simulated PDF

\begin{tabular}{||l|r|r|}
\hline & Simulated PDF & Bone Dry Basis \\
\hline Moisture & 3.29 & -- \\
\hline Volatiles & 17.50 & 18.10 \\
\hline Fixed Carbon & 70.03 & 72.41 \\
\hline Ash. & 9.18 & 9.49 \\
\hline BTU/lb & 11,641 & 12,037 \\
\hline
\end{tabular}

\subsubsection{Commercial Testing and Engineering Analysis.}

A sample of simulated PDF was sent to Commercial Testing and Engineering, Inc. in South Holland, IL for Proximate analysis, Ultimate analysis, and associated tests to determine forms of sulfur, grindability, percent equilibrium moisture, and apparent specific gravity. Table VI summarizes the results for the Proximate and Ultimate analysis including the heat of combustion. Data sheets for this analysis may be found in Appendix $\mathrm{I}$.

Table VI CTE Simulated PDF Proximate and Ultimate Analysis Results

\begin{tabular}{||l|l|r|r|}
\hline \multicolumn{1}{|c|}{ Method } & \multicolumn{1}{|c|}{ Sample } & Simulated PDF & Bone Dry Basis \\
\hline D 3302 & \% Moisture & 2.23 & -- \\
\hline D 3175 & \% Volatiles & 24.19 & 24.74 \\
\hline D 3172 & \% Fixed Carbon & 61.35 & 62.75 \\
\hline D 3174 & \% Ash & 12.23 & 12.51 \\
\hline Infrared & \% Carbon & 72.60 & 74.26 \\
\hline Infrared & \% Hydrogen & 3.08 & 3.15 \\
\hline TC & \% Nitrogen & 1.29 & 1.32 \\
\hline D 4239 & \% Sulfur & 1.39 & 1.42 \\
\hline D 2015 & Heat of Combustion, BTU/lb & 11,940 & 12,212 \\
\hline
\end{tabular}


Other coal properties such as forms of sulfur, grindability, equilibrium moisture, and apparent specific gravity, as determined by CTE, are summarized in Table VII.

Table VII CTE PDF Analysis

\begin{tabular}{||l|l|c|c||}
\hline \multicolumn{1}{|c|}{ Method } & \multicolumn{1}{|c|}{ Analysis } & \multicolumn{2}{c|}{ PDF } \\
\hline D 2492 & Forms of Sulfur & A.R. & B.D. \\
\hline & \% Pyritic & 0.91 & 0.93 \\
\hline & \% Sulfate & 0.01 & 0.01 \\
\hline & \% Organic (diff) & 0.47 & 0.48 \\
\hline D 409 & \multicolumn{1}{|c|}{ Total } & 1.39 & 1.42 \\
\hline D 3180 & Grindability & \multicolumn{2}{|c|}{12.1} \\
\hline USX Method & \% Equilibrium $\mathrm{H}_{2} \mathrm{O}$ & \multicolumn{2}{|c|}{91} \\
\hline & USX Oxidation Index & \multicolumn{2}{|c|}{1.20} \\
\hline
\end{tabular}

Based on CTE's analysis, the sulfur dioxide emission for the simulated PDF is $2.3 \mathrm{lbs}$ $\mathrm{SO}_{2}$ /MMBTU.

\subsection{Analysis}

The Development Center obtained ${ }^{1} \mathrm{H}$ and ${ }^{13} \mathrm{C}$ NMR spectra of the CDL. Samples of CDL also were sent to Commercial Testing and Engineering, Inc., and the National Institutes for Occupational Safety and Health for analysis.

\subsubsection{SGI's Development Center, NMR Analysis}

NMR spectra are generally displayed on a chemical shift basis designated $\delta$ with units of ppm. Chemical shift is defined as:

$$
\delta_{i}=\frac{v_{i}-v_{T M S}}{v_{0}} \times 10^{6}
$$

where $v_{i}$ is the resonate frequency of nucleus $\mathrm{i}, v_{0}$ is the operating frequency of the instrument, and $v_{\text {TMS }}$ is the resonate frequency of the protons (or ${ }^{13} \mathrm{C}$ nuclei) in the internal standard, tetramethylsilane. For the proton spectra, the operating frequency of the instrument $\left(v_{0}\right)$ is $400 \mathrm{MHz}$, and for the ${ }^{13} \mathrm{C}$ spectra, $v_{0}=101 \mathrm{MHz}$.

Reproductions of the ${ }^{1} \mathrm{H}$ and ${ }^{13} \mathrm{C}$ spectra may be found in the Appendix II.

\section{Proton $\left({ }^{1} \mathrm{H}\right)$ Spectra}

The proton NMR spectra may be divided into two general areas. At low chemical 
shift ( $\delta=0$ to $3 \mathrm{ppm}$ ), one finds peaks associated with protons attached to saturated carbons, and at higher chemical shift $(\delta=6$ to $8 \mathrm{ppm})$, one finds peaks associated with protons attached to aromatic carbons. The area between the saturated (or aliphatic) and the aromatic regions is occupied by peaks for protons bound to isolated carbon-carbon double bonds and protons bound directly to hetero atoms such as oxygen and nitrogen.

The major peak observed in the CDL proton spectra is a sharp signal centered at 1.25 ppm. This signal corresponds to protons bound to carbons in straight chain hydrocarbons $\left(-\mathrm{CH}_{2}-\right)$.

The CDL also shows a signal centered at $3.7 \mathrm{ppm}$. This peak is in the general region of the proton NMR spectrum where hetero-atom bound methyl or methylene functions are found (i.e., $-\mathrm{O}-\mathrm{CH}_{3}$ or $-\mathrm{O}-\mathrm{CH}_{2}-$ ).

The ratios of "saturated" protons (protons bound to saturated carbon atoms) to "aromatic" protons (protons bound to aromatic carbon atoms) may be determined by integrating the area under the peaks in the appropriate regions. Table VIII summarizes these areas and the ratio of saturated to aromatic protons for Knife River CDL.

Table VIII Proton NMR Peak Areas

\begin{tabular}{||r|r|r|r|}
\hline & \multicolumn{2}{|c|}{ AREAS } & \\
& Aromatic (A) & Saturated (S) & Ratio (S/A) \\
\hline Knife River CDL & 86.7 & 148.6 & 1.71 \\
\hline
\end{tabular}

\section{Carbon $\left({ }^{13} \mathrm{C}\right)$ Spectra}

All of the ${ }^{13} \mathrm{C}$ spectra are proton noise decoupled. This reduces the complexity of the spectra (each carbon shows up as a singlet) and enhances the signal to noise ratio. This enhancement is important because the procedure relies on the natural abundance of ${ }^{13} \mathrm{C}$ for the NMR measurement $\left({ }^{12} \mathrm{C}\right.$ is not sensitive to the NMR experiment). The natural abundance of ${ }^{13} \mathrm{C}$ is $1.1 \%$ and its relative sensitivity is only 0.016 (proton $=$ 1). Therefore, the ${ }^{13} \mathrm{C}$ signal is $1.2 \times 10^{-5}$ weaker than that of ${ }^{1} \mathrm{H}$. For these reasons, ${ }^{13} \mathrm{C}$ atoms which do not carry a proton have very weak signals and are usually lost in the baseline.

As in proton NMR spectra, the low chemical shift region ( $\delta=0$ to $40 \mathrm{ppm}$ ) is generally populated by saturated $\left(-\mathrm{CH}_{2}-\right.$, and $\left.\mathrm{CH}_{3}-\right)$ carbons, and the high chemical shift region $(\delta=110$ to $140 \mathrm{ppm})$ is populated by aromatic carbons. For ${ }^{13} \mathrm{C}$ spectra this is, however, an over simplification because ketone, aldehyde, and carboxylic acid carbons may be found at even higher chemical shifts ( $\delta=160$ to $220 \mathrm{ppm}$ ), and unsaturated carbons will overlap into the lower part of the aromatic region.

The major peak found in the $\mathrm{CDL}{ }^{13} \mathrm{C}$ spectra is centered at $29.6 \mathrm{ppm}$. Proton decoupling experiments show this peak to be due to methylene $\left(-\mathrm{CH}_{2}-\right)$, suggesting the presence of long chain hydrocarbons. A second ${ }^{13} \mathrm{C}$ NMR signal is located at $5.56 \mathrm{ppm}$. Decoupling experiments show this peak to be due to a methyl group $\left(\mathrm{CH}_{3}-\right)$. Its chemical shift identifies it as a methyl group bound to a hetero atom, 
probably oxygen.

\subsubsection{Commercial Testing and Engineering}

A sample of the CDL was sent to Commercial Testing and Engineering's (CTE) South Holland, IL laboratory for analysis. Table IX summarizes the results of these tests. Data sheets for these analysis may be found in Appendix I.

Table IX Commercial Testing and Engineering Blended CDL Analysis

\begin{tabular}{||l|l|r||}
\hline \multicolumn{1}{|c|}{ Method } & \multicolumn{1}{|c|}{ Analysis } & \multicolumn{1}{c|}{ Result } \\
\hline D 287 & Specific Gravity & 1.0801 \\
\hline D 240 & Heating Value, BTU/b & 13,957 \\
\hline D 95 & Water, wt. \% & 6.8 \\
\hline D 473 & Sediment, wt. \% & 0.57 \\
\hline D 97 & Pour Point, $^{\circ}$ F & 65 \\
\hline & Cold Point, $^{\circ}$ F & 60 \\
\hline D 93 & Flash Point, ${ }^{\circ}$ F & 150 \\
\hline Infrared & \% Carbon & 71.18 \\
\hline Infrared & \% Hydrogen & 7.12 \\
\hline TC & \% Nitrogen & 1.01 \\
\hline D 1552 & \% Sulfur & 0.69 \\
\hline D 482 & \% Ash & 0.04 \\
\hline & \% Oxygen (diff.) & 13.16 \\
\hline
\end{tabular}

CTE also conducted an atmospheric distillation analysis (D 86) of the CDL sample. The results of this analysis are provided in Table $\mathrm{X}$.

\subsubsection{National Institute for Occupational Safety and Health (NIOSH)}

Samples of CDL were submitted to NIOSH for mutagenic testing. The NIOSH sample designation for Knife River CDL is MR3. To summarize their results, Knife River CDL was shown to be weakly mutagenic. The NIOSH report may be found in Appendix III. 
Table X Knife River CDL Distillation Analysis

\begin{tabular}{||l|l||}
\hline $\begin{array}{l}\text { Percent } \\
\text { Distilled }\end{array}$ & $\begin{array}{l}\text { CTE } \\
\text { Atmospheric }\end{array}$ \\
\hline IPB & 212 \\
\hline 5 & 218 \\
\hline 10 & 402 \\
\hline 20 & 422 \\
\hline 30 & 437 \\
\hline 40 & 467 \\
\hline 50 & 497 \\
\hline 60 & 544 \\
\hline 70 & 589 \\
\hline 80 & 602 Oil Brake \\
\hline$\%$ Recovered & 76.0 \\
\hline
\end{tabular}

\subsection{Conclusions}

The co-product production runs conducted in November 1992 have yielded sufficient simulated PDF and CDL to meet the production needs for the Williston Basin Coal (Knife River Mine). The analysis of the PDF suggests that the pyrolysis removed about $58 \%$ of the volatiles in the feed coal. This coal was very difficult to process in the SPU and caused frequent plugging of the down stream equipment.

The blend of equal amounts of the three Knife River coal seams contains $2.03 \%$ sulfur on a dry basis. This coal blend would produce about $3.7 \mathrm{lbs} \mathrm{SO} / \mathrm{MMBTU}$ when burned. During pyrolysis, some of the organic sulfur in the coal is removed with the volatiles, and thus, the effective sulfur emissions for the PDF would be less than that for the raw coal. The Knife River PDF blend would produce $2.3 \mathrm{lbs}$. $\mathrm{SO}_{2}$ /MMBTU when burned.

The overall yield of CDL was $4 \%$ based on the raw coal and $6.9 \%$ based on dry coal (corrected for moisture in the CDL but not corrected for losses of coal during processing). The CDL is a low sulfur co-product containing only $0.22 \%$ sulfur by weight. The distillation curve in Figure 1 shows the $\mathrm{CDL}$ to be a heavier oil than normal crude, but the molar $\mathrm{H} / \mathrm{C}$ ratio of 1.19 suggests that the coproduct is refinable.

The NIOSH mutagenic testing determined that the Knife River CDL is only weakly mutagenic. 


\section{Knife River CDL Distillation Curve}

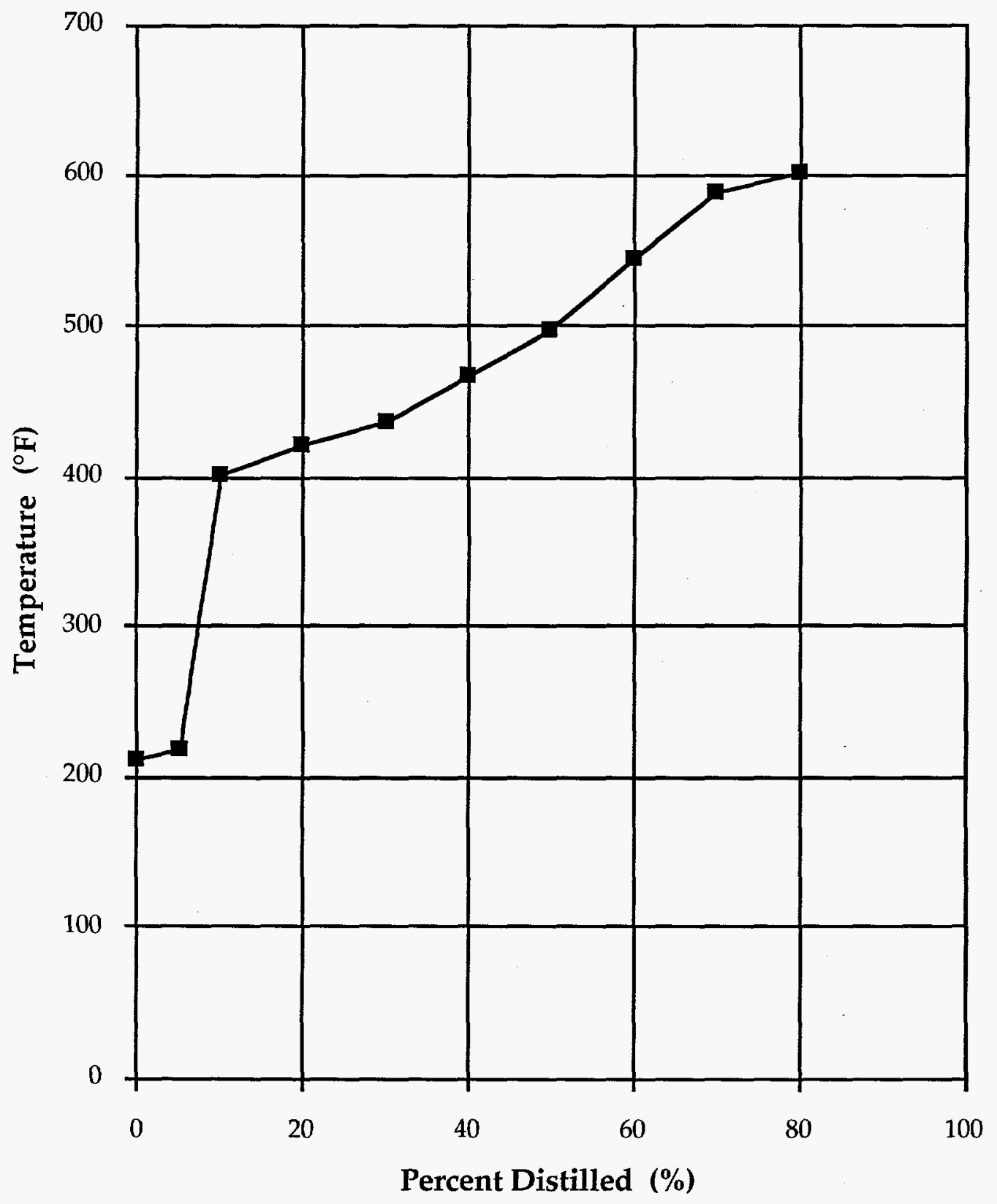

Figure 1. CDL Distillation Curve 
Appendix I Commercial Testing and Engineering Analysis Sheets 
December 21, 1992

MAUMEE RESEARCH \& ENGR., INC.

27457 Holiday Iane, suite G Perrysburg, OH 43551

ATTN: Dr. Deane A. Home

Sample identification by

Maumee Research \& Engr., Inc.

kind of sample

reported to us Raw Coal

Sample ID: Knife River

Raw Coal

Sample taken at .....

Seam 1, 2, \& 3

Sample taken by .....

Date sampled -....

Date received December 11, 1992

P. O. 04655

Analysis Report No. $71-46978$

Page 1 of 1

\section{PROXIMATE ANALYSIS}

As Received

is Moisture

\& Ash

\& Volatile

\& Fixed Carbon

Btu/Ib.

\& Sulfur

MAF Btu

FORMS OF SULFUR

\& Pyritic

\& Sulfate

\& Organic (diff)

Total
Dry Basis

ULTIMATE ANALYSIS

As Received Dry Basis

\begin{tabular}{rr}
32.65 & $x \times \times \times x$ \\
6.93 & 10.29 \\
29.46 & 43.74 \\
30.96 & 45.97 \\
\hline 100.00 & 100.00 \\
7367 & 10939 \\
1.37 & 2.03 \\
& 12194
\end{tabular}

\% Moisture

32.65

42.79

\& Carbon

\% Hydrogen

\& Nitrogen

3.20

\& Sulfur

\& $\mathrm{Ash}$

0.84

1.37

6.93

\& Oxygen (diff)

$\frac{12.22}{100.00}$

$\mathrm{xxxxx}$

63.53

4.75

1. 24

2.03

10.29

18.16

12194

\author{
GRINDABIIITY INDEX $=47$ \\ \% EQUILIIBRIUM MOISTURE $=33.8$ \\ OXIDATION INDEX $=3$ \\ APPARENT SPECIFIC GRAVITY $=1.33 \mathrm{~g} / \mathrm{CC}$
}


January 2, 1993

MAUUMEE RESEARCH \& ENGR., INC.

27457 Holiday Lane, Suite G

Perrysburg, $\mathrm{OH} 43551$

ATTN: Dr. Deane A. Home

Sample identification by

Maumee Research \& Engr., Inc.

Kind of sample

reported to us simulated Coal Char

Sample ID: Simulated PDF Knife River Coal Char

Sample taken at .....

Seam $1,2, \& 3$

Sample taken by .....

Date sampled -.....

Date received December 11, 1992

P.O. 04655

Analysis Report No. 71-46977 $\quad$ Page 1 of 1

\section{PROXIMATE ANALYSIS}

\section{As Received}

\& Moisture

$8 \mathrm{Ash}$

\& volatile

\& Fixed Carbon

Btu/1b.

\& Sulfur

MAF Btu

FORMS OF SULFUR

\& Pyritic

\& Sulfate

8 Organic(diff)

TotaI

$$
\begin{array}{r}
2.23 \\
12.23 \\
24.19 \\
61.35 \\
\hline 100.00
\end{array}
$$

11940

1.39

0.91

0.01

0.47

1.39

\section{ULTIMATE ANALYSIS}

\section{Dry Basis}

$$
\begin{aligned}
& x \times x \times x \\
& 12.51 \\
& 24.74 \\
& 62.75 \\
& \hline 100.00
\end{aligned}
$$

12212

1.42

13958
As Received Dry Basis

\& Moisture

\& Carbon

2.23

72.60

3.08

\& Nitrogen 1.29

\& Sulfur

of Agh

\& Oxyger (diff)

1.39

12.23

$\frac{7.18}{100.00}$

$\mathrm{xxxxx}$

74.26

3.15

1.32

1.42

12.51

$\frac{7.34}{100.00}$
65 GRINDABILITY INDEX = 51

\% EQUILLIBRIUM MOISTURE $=12.1$

0.93

0.01

OXIDATION INDEX $=91$

APRARENT SPECIFIC GRAVITY $=1.20 \mathrm{~g} / \mathrm{CC}$ 0.4834

1.42 
January 7, 1993

MAUMEE RESEARCH \& ENGR. INC.

27457 Holiday Lane, Suite G

Perrysburg, OH 43551

ATTN: Dr. Deane A. Home

Sample identification by

Maumee Research \& Engr., Inc.

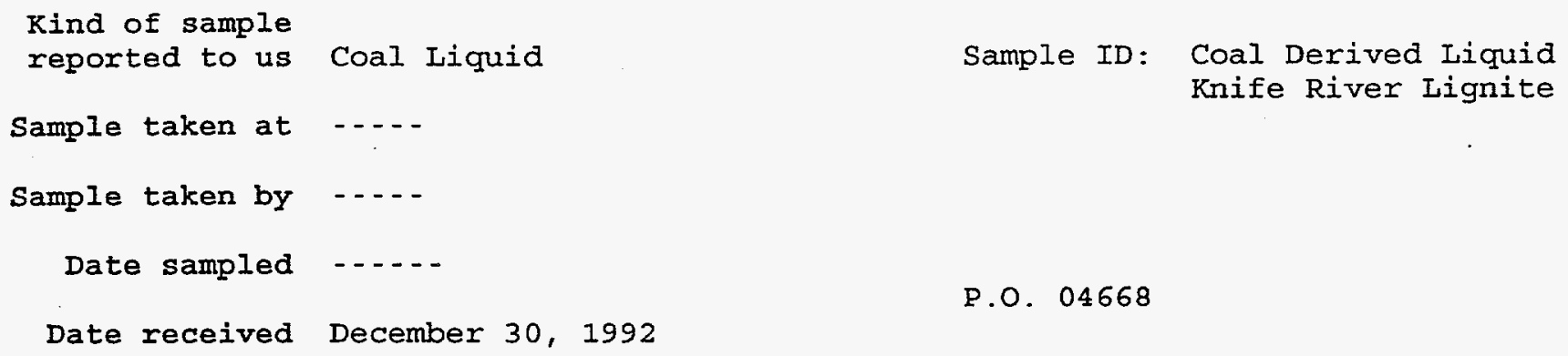

Sample ID: Coal Derived Liquid

Knife River Lignite

As Received

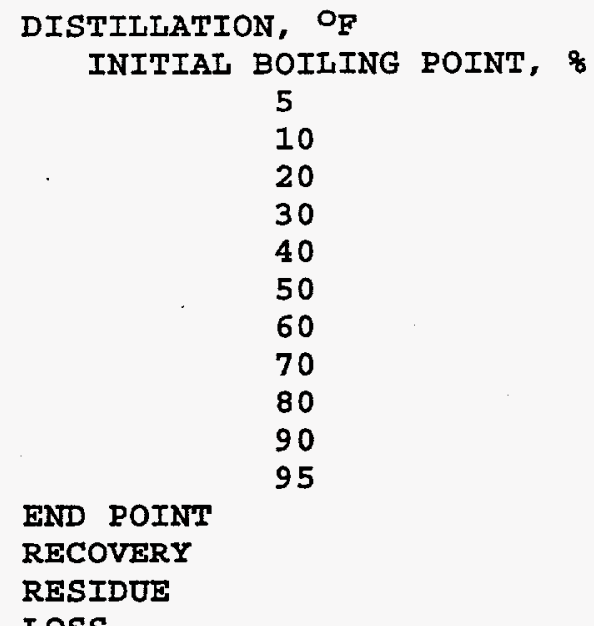

212

218

402

422

437

467

497

544

589

$602 *$
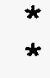

*

76.0

25.0

0.0

* NOTE Oil Brake, Fumes coming out.

Method: Distillation per ASTM Designation D 86 
January 7, 1993

MAUMEE RESEARCH \& ENGR., INC.

27457 Holiday Lane, Suite G

Perrysburg, OH 43551

Sample identification by

ATTN: Dr. Deane A. Home

Maumee Research \& Engr., Inc.

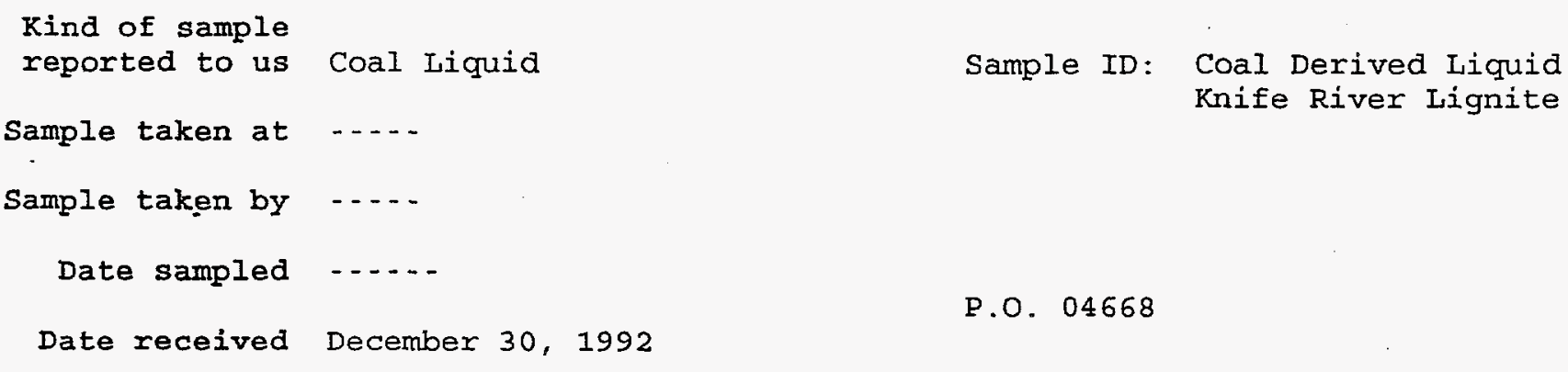

Analysis Report No.

$71-47840$

Page 2 of 3

\begin{tabular}{lr} 
GRAVITY & As Received \\
\cline { 2 - 2 } Specific at $60 / 600^{\circ}$ & 1.0801 \\
Ib/galion at $50^{\circ} \mathrm{F}$ & 8.998 \\
HEATING VALUE & \\
\hline Btu/1b & 13,957 \\
Btu/ga1 at $60^{\circ} \mathrm{F}$ & 125,585 \\
WATER, \& Wt. & 6.80 \\
SEDIMENT, \& Wt. & 0.57 \\
POUR POINT, OF & 65 \\
COID POINT & 60 \\
FLASHPOINT, OF & \\
CLEVILAND OPEN CUP & 158
\end{tabular}

Methods: Gravity per ASTM Designation D-287-82

Heating Value per ASTM Designation D-240-87

Ash per ASTM Designation D-482-87

Water per ASTM Designation D-95-83

Pour and Cold Point per ASTM Designation D-97-87

Sediment per ASTM Designation D 473

Flashpoint per ASTM Designation D 93 
January 7, 1993

MAUMEE RESEARCH \& ENGR., INC.

27457 Holiday Lane, Suite G

Perrysburg, OH 43551

ATTN: Dr. Deane A. Home
Sample identification by

Maumee Research \& Engr., Inc.

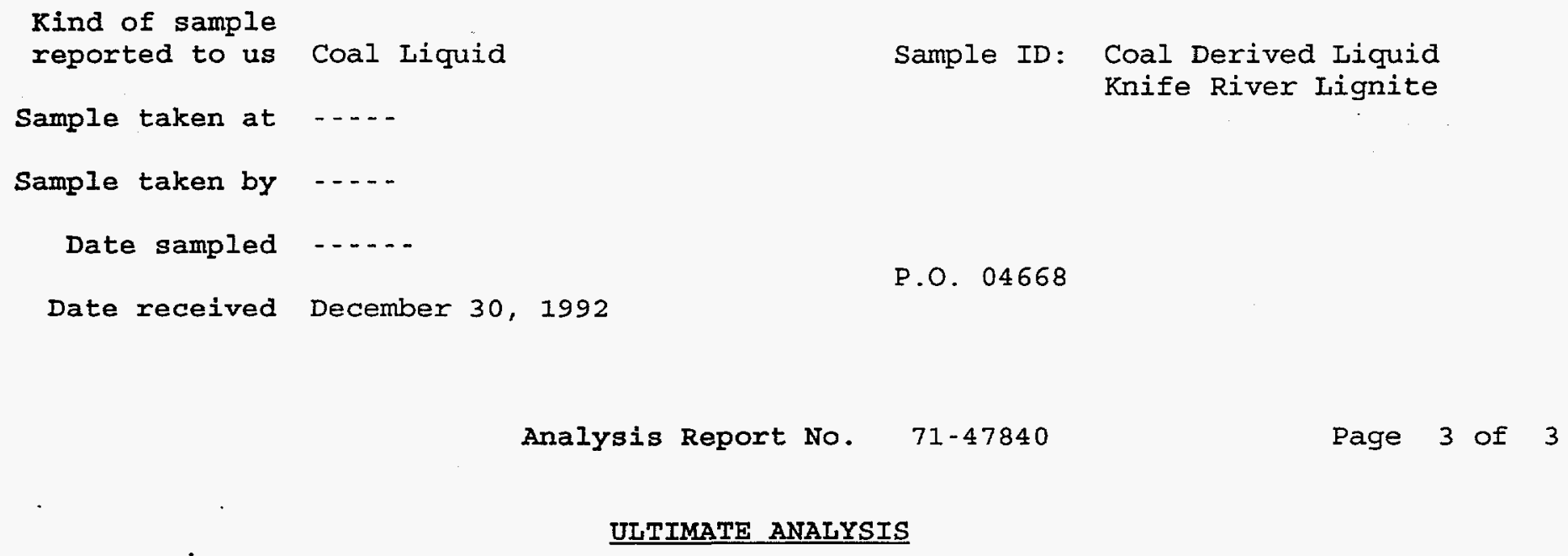

Sample ID: Coal Derived Liquid Knife River Lignite

As Received
\& Water
\& Carbon
\& Hydrogen
\& Nitrogen
\& Sulfur
of Ash
\& Oxygen (diff)

$$
\begin{array}{r}
6.80 \\
71.18 \\
7.12 \\
1.01 \\
0.69 \\
0.04 \\
13.16 \\
\hline 100.00
\end{array}
$$

Methods: Water per ASTM Designation D 95

Carbon, Hydrogen and Nitrogen per LECO CHN/600 Sulfur per ASTM Designation D 1552

Ash per ASTM Designation D-482 
Appendix II ${ }^{13} \mathrm{C}$ and ${ }^{1} \mathrm{H}$ NMR Spectra of CDL 


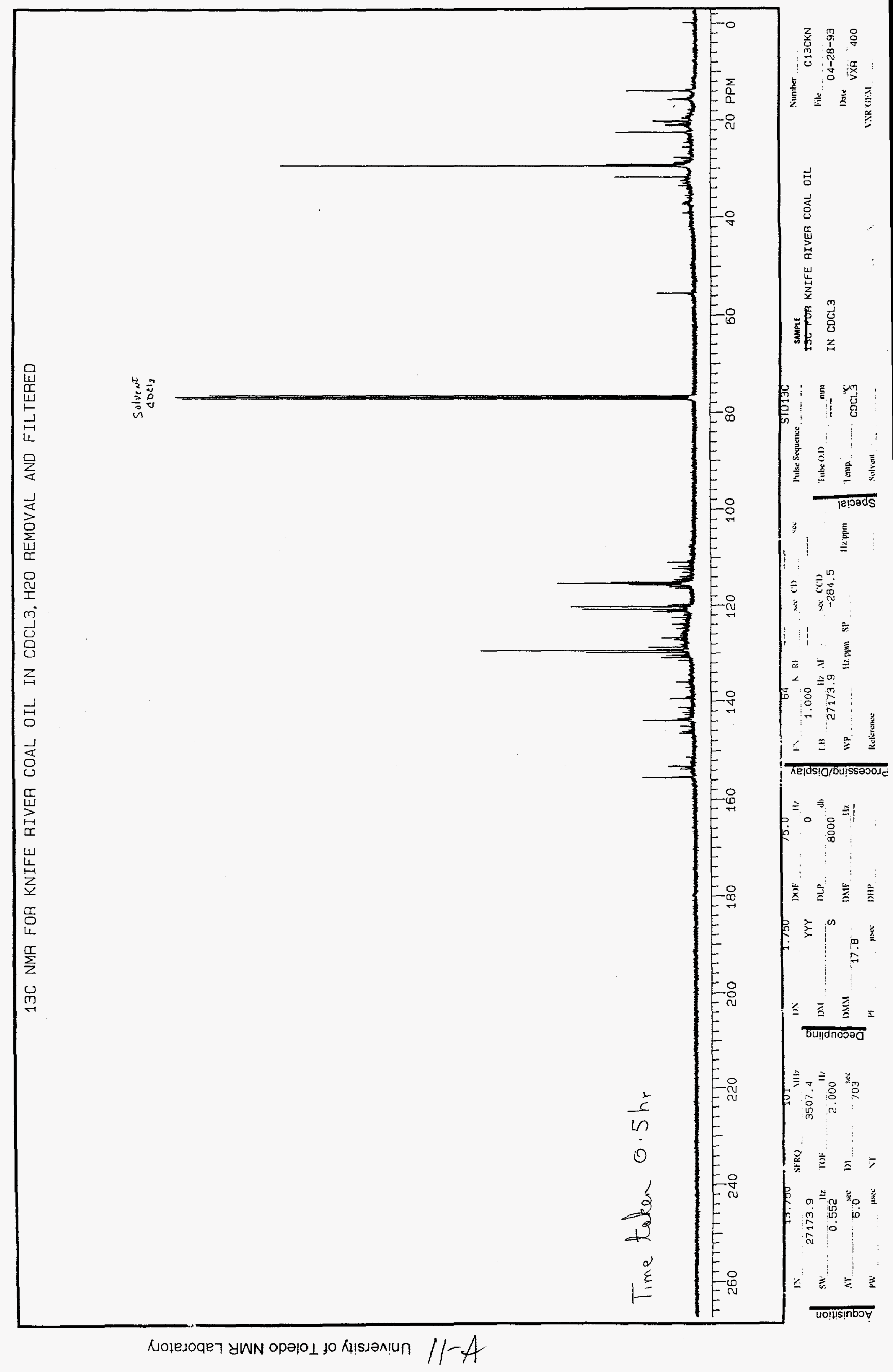




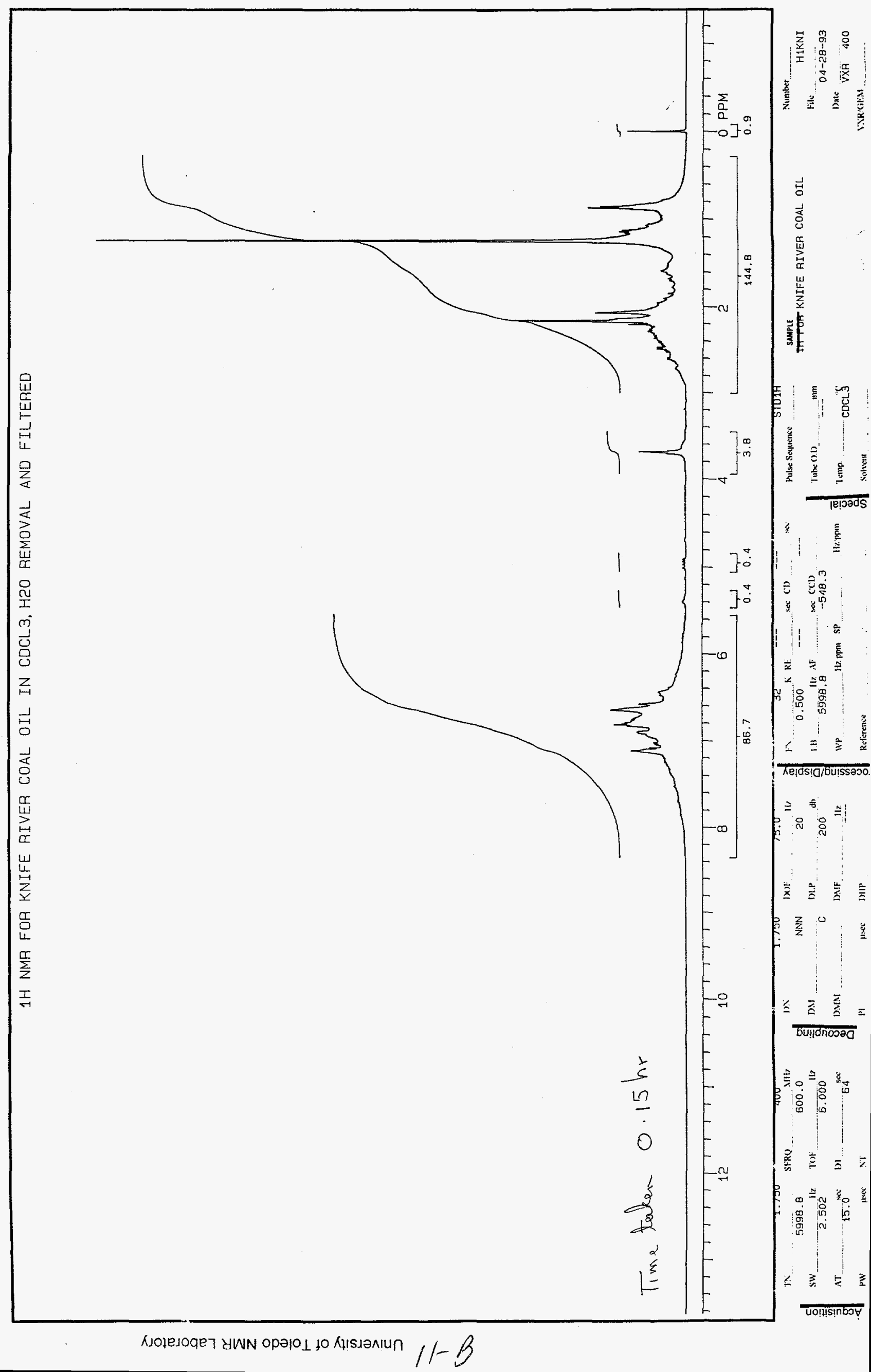


D- 11 University of Toledo NMR Laboratory

\section{Ácquisition}

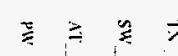

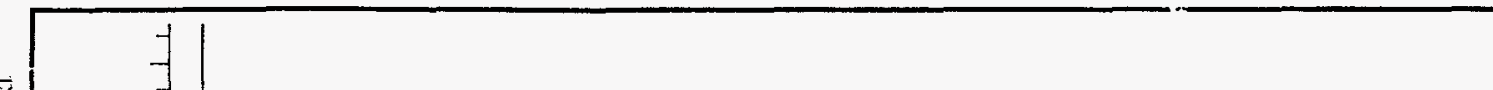

$=$

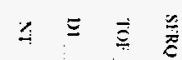

$\approx \equiv$

Decoupling

$\Xi \bar{\Xi} \Xi \bar{E}$

$\bar{z}$

禀

葛

$\approx \equiv$

cessing/Display

永

$\bar{z}$

$=$

(1)

$\because$

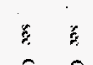

$\hat{\Xi} \hat{}$

三

jpecie

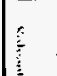

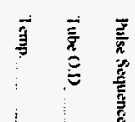

$\div$

啝| 旁

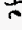

8

$2-3.6918$

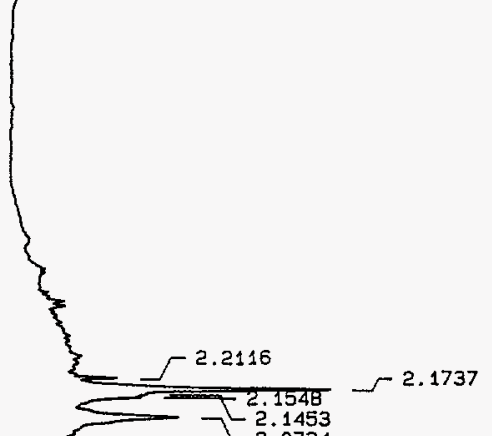

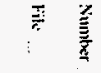


Appendix III National Institute for Occupational Safety and Health Data Sheets 
Centers for Disease Control

National Institute for Occupational

Safety and Health - ALOSH

944 Chestnut Ridge Road

Morgantown, WV 26505-2888

November 1, 1993

Deane A. Horne, Ph.D.

Maumee Research and Engineering, Inc.

27457 Holiday Lane, Suite G

Perrysburg, OH 43551

Dear Dr. Horne,

The enclosed three reports contain the results of genotoxicity studies conducted by NIOSH on the four coal-derived liquid fuel samples received from Maumee Research and Engineering, Inc. (reference: Contract No. DE-AC21-91MC27240), per your request by telephone today.

Our designation of the samples is as follows:

CL201 Buckskin, Powder River Basin

MRE 1 Sarpy Creek, Rosebud Seam

MRE 2 Usibelli (Alaska)

MRE 3 Knife River, Williston Basin

If you have any questions about the reports, please let us know.

Sincerely,

Lusax B. Robbins

Susan B. Robbins

Microbiology Section

Division of Respiratory Disease Studies

Encl.: Mutagenicity of CL201 in the Ames Assay

Mutagenicity of MRE 1, MRE 2, and MRE 2 in the Ames Assay

The Genotoxicity Studies of Mild Gasification Product MRE 1 in Mammalian Cells 


\section{Mutagenicity of MRE 1, MRE 2, and MRE 3 in the Ames Assay}

\section{INTRODUCTION}

Mild gasification of coal is a technology being developed by the United States Department of Energy (DOE) and private industry with the hope that a cleaner method of coal use can help meet future energy needs. As the technology develops and its commercial use becomes a more viable possibility, efforts are being made to study the safety and possible toxicity of the mild gasification products. DOE and the National Institute for Occupational Safety and Health (NIOSH) are cooperating through an interagency agreement to examine some of these products for their genotoxic potential.

NIOSH has studied the mutagenicity of several mild gasification product samples using the Ames Salmonella microsomal assay (Maron and Ames, 1983). The Ames assay is widely used as a short-term test for the detection of possible genotoxic agents and potential carcinogens. Bacterial tester strains used in the Ames assay contain specific mutations (frameshift or base pair substitution) that cause the bacteria to be dependent on growth medium containing the amino acid histidine. The mutagenic activity of a test substance is measured by the number of reverse mutations eliminating the histidine requirement. Mutation is generally accepted to be involved in the initiation stage of carcinogenesis; therefore, the Ames assay has often been used as the first tier of testing in the evaluation of long-term health risks associated with exposure to certain chemicals.

\section{METHODS AND MATERIALS}

\section{Sample description}

MRE 1 has a liquid/tar consistency and a boiling point of $216^{\circ} \mathrm{F}$. The sample was made from a 50:50 mix of low- and high-sodium Montana coal and obtained from Maumee Research and Engineering, Inc. (MRE).

MRE 2 has a liquid/tar consistency, with a boiling point of $212^{\circ} \mathrm{F}$. It was made from Alaskan coal and obtained from MRE.

MRE 3 also has a liquid/tar consistency, with a boiling point of $212^{\circ} \mathrm{F}$. The sample was made from North Dakota lignite coal and obtained from MRE.

Chemicals

Positive controls:

2-aminoanthracene (2AA), a chemical mutagen which requires metabolic activation $(+\mathrm{S} 9)$, and trinitrofluorenone (TNF), a direct acting mutagen (-S9), were used in the assay system at final concentrations of $2.5 \mu \mathrm{g} / \mathrm{plate}$ and $0.4 \mu \mathrm{g} /$ plate, respectively. Both were purchased from Aldrich Chemical Company, Milwaukee, Wisconsin. 
Solvent control:

Dimethylsulfoxide (sterile, spectrophotometric grade) was purchased from EM Science, Cherry Hill, New Jersey.

\section{Sample preparation}

The sample was dissolved in DMSO to the desired concentrations, using methodologies similar to those described by Ma et al. (1983). The mixture was heated to $50^{\circ} \mathrm{C}$ and sonicated in a Branson model 3200 water bath/sonicator for 30 minutes to facilitate homogenization. The mixture was warmed, sonicated, and vortexed until a homogeneous solution was obtained. Lower concentrations of each sample was obtained by serial dilution of the original solution. The positive controls were prepared in a manner similar to the sample to ensure consistent experimental design.

\section{Ames Salmonella microsomal Assay}

The mutagenicity of each sample was determined using the pre-incubation variant of the Ames Salmonella microsomal assay system (Maron and Ames, 1983), which is frequently more sensitive than the standard protocol. The sample was tested on TA98 and TA100 bacterial tester strains. Each concentration on each tester was tested with and without metabolic activation by S9, a preparation made from the livers of Aroclor 1254-treated male Wistar rats. Each of these treatments was tested in triplicate. In a test tube, $0.1 \mathrm{ml}$ of the sample or a control chemical was combined with $0.1 \mathrm{ml}$ overnight bacterial culture and 0.5 $\mathrm{ml}$ S9 preparation or $0.5 \mathrm{ml}$ physiological saline. Each test tube was vortexed and incubated on a rotary shaker at $37^{\circ} \mathrm{C}$ for 30 minutes prior to adding $2.5 \mathrm{ml}$ molten $\left(45^{\circ} \mathrm{C}\right)$ top agar and pouring the mixture onto a petri dish. After the top agar solidified, the dishes were inverted and incubated for 48 hours at $37^{\circ} \mathrm{C}$. The top agar contained a trace amount of histidine which is required for initial bacterial growth. After several rounds of cell division, the histidine present was depleted. Only those bacteria that had mutated to be histidineindependent continued to grow and form a colony. Those bacteria are called revertants because they have reverted (in that trait only) back to the wild-type Salmonella. The revertant colonies were scored on an automatic colony counter. The criteria for positive mutagenic activity in the Ames assay is a doubling of the solvent control in the number of revertants, accompanied by a dose-related increase in revertant numbers. The positive controls allow us to be certain that the bacteria grew and the $\mathbf{S 9}$ worked properly.

\section{RESULTS AND DISCUSSION}

MRE 1 displayed consistant, reproducable mutagenic activity in TA98 in the presence of S9 metabolic activation. The number of revertant colonies was three to four fold higher than that of the solvent control. The sample also displayed some doubling of the solvent control in TA100 with S9 (Table 1), but that activity could not be confirmed and therefore is not considered to be positive. MRE 2 and MRE 3 also displayed some doubling of the solvent 
control activity on TA98 with S9, but less so than MRE 1. The dose-response in those two samples was less obvious as well as inconsistent.

The histidine dependence in TA98 is due to a frameshift mutation, which skews the reading frame of the genetic code, while the histidine dependence in TA100 may be due to a frameshift mutation or a base-pair substitution. The reversion of either mutation requires another event of the same type mutation, so the evidence of mutagenic activity in TA98, and less so in TA100 indicates that the samples most likely contain frameshift mutagens. The fact that the activity is only present when S9 is added and not without S9 indicates that the samples require metabolic activation, in which case mutagens present are referred to as indirect-acting mutagens.

Based on this study, it appears that MRE 1 is mutagenic, probably inducing frameshift mutations after metabolic activation. MRE 2 and MRE 3 are weakly mutagenic, most likely containing indirect-acting frameshift mutagens.

\section{REFERENCES}

Ma, C.Y., C.H. Ho, R.B. Quincy, M.R. Guerin, T.K. Rao, B.E. Allen, and J.L. Epler (1983) Preparation of oils for bacterial testing, Mutat. Res., 118:15-24.

Maron, D.M., and B.N. Ames, 1983. Revised methods for the Salmonella mutagenicity test. Mutat Res, 113:173-215. 
TABLE I

Mutagenicity Testing of MRE 1, MRE 2, and MRE 3

\begin{tabular}{|c|c|c|c|c|c|}
\hline \multirow[b]{3}{*}{ Sample } & \multirow{3}{*}{$\begin{array}{c}\text { Concentration } \\
\mu \mathrm{g} / \mathrm{plate}\end{array}$} & \multicolumn{4}{|c|}{ Average Number of Revertant Colonies per Plate } \\
\hline & & \multicolumn{2}{|c|}{ TA 98} & \multicolumn{2}{|c|}{ TA 100} \\
\hline & & $-\mathrm{S} 9$ & $+\mathrm{S} 9$ & -59 & +59 \\
\hline \multirow[t]{7}{*}{ MRE 1} & $0^{\mathrm{A}}$ & 22 & 28 & 86 & 102 \\
\hline & 15.6 & 37 & $-{ }^{B}$ & - & - \\
\hline & 31.25 & 36 & $76^{*}$ & 135 & 167 \\
\hline & 62.5 & 30 & $96^{*}$ & 151 & 169 \\
\hline & 125 & $19^{\mathrm{C}}$ & $96^{*}$ & 129 & 222 \\
\hline & 250 & - & $101^{*}$ & $46^{\mathrm{C}}$ & 211 \\
\hline & 500 & - & - & - & 140 \\
\hline \multirow[t]{7}{*}{ MRE 2} & $0^{\mathrm{A}}$ & 22 & 28 & 86 & 102 \\
\hline & 31.25 & 33 & 41 & - & - \\
\hline & 62.5 & 33 & $66^{*}$ & 109 & - \\
\hline & 125 & 28 & $58^{*}$ & 141 & 168 \\
\hline & 250 & $19^{\mathrm{C}}$ & 54 & $89^{\mathrm{c}}$ & 161 \\
\hline & 500 & - & 47 & $50^{\mathrm{C}}$ & 188 \\
\hline & 1000 & - & - & - & 113 \\
\hline \multirow[t]{7}{*}{ MRE 3} & $0^{\mathrm{A}}$ & 22 & 28 & 86 & 102 \\
\hline & 15.6 & 40 & $=$ & - & - \\
\hline & 31.25 & 41 & - & 111 & - \\
\hline & 62.5 & $19^{C}$ & 50 & 137 & 111 \\
\hline & 125 & $1^{\mathrm{C}}$ & $68^{*}$ & 125 & 157 \\
\hline & 250 & - & $63^{*}$ & $48^{c}$ & 213 \\
\hline & 500 & - & $77^{*}$ & - & 194 \\
\hline \multirow[t]{2}{*}{$2 \mathrm{AA}$} & $0^{\mathrm{A}}$ & 22 & 28 & 86 & 102 \\
\hline & 2.5 & - & 1176 & - & 1787 \\
\hline \multirow[t]{2}{*}{ TNF } & $0^{\mathrm{A}}$ & 22 & 28 & 86 & 102 \\
\hline & & 980 & - & - & - \\
\hline
\end{tabular}

${ }^{A}$ DMSO solvent control ${ }^{\mathrm{B}}$ Not tested ${ }^{\mathrm{C}}$ Too much cytotoxicity * Positive response 